\title{
What is the evidence-base for atopic eczema treatments? A summary of published randomised controlled trials
}

\author{
H Nankervis ${ }^{1}$, KS Thomas ${ }^{1}$, FM Delamere ${ }^{1}$, S Barbarot ${ }^{1}$, Sherie Smith ${ }^{1}$, NK Rogers ${ }^{1}$ and HC Williams ${ }^{1 *}$ \\ ${ }^{1}$ Centre of Evidence Based Dermatology, University of Nottingham, King's Meadow Campus, Lenton Lane, Nottingham, NG7 2NR \\ *Corresponding author: Hywel C. Williams; Centre of Evidence Based Dermatology, University of Nottingham, King's Meadow Campus, \\ Lenton Lane, Nottingham, NG7 2NR. Email: hywel.williams@nottingham.ac.uk \\ Funding: \\ This publication presents independent research funded by the National Institute for Health Research (NIHR) under its \\ Programme Grants for Applied Research Programme (RP-PG-0407-10177). The views expressed in this publication are those \\ of the author(s) and not necessarily those of the NHS, the NIHR or the Department of Health. \\ SB received a grant from Le Collège des Enseignants en Dermatologie de France (CEDEF) to support his work on this project \\ in his role as visiting Fellow at the Centre of Evidence Based Dermatology \\ Conflict of interest disclosures:
}

SB has received grants from Pierre Fabre Laboratory, personal fees from GlaxoSmithKline and Sinclair Pharma and grants and personal fees from Astellas.

HCW is Director of the NIHR Health Technology Assessment programme.

KST and HCW are authors on two of the trials included in this review.

All other authors: nothing to disclose.

Keywords: eczema, atopic dermatitis, treatment, systematic review

Main text: 2772 (maximum 3000 words)

Abstract: 249 (maximum 250 words)

\section{What's already known about this topic?}

- The evidence base for atopic eczema (AE) treatments is broad and limited by poor quality trials

- The last systematic review to provide an overview of all published AE randomised controlled trials (RCTs) was conducted in 2000

\section{What does this study add?}

- Over 500 RCTs have been published on treatments for $\mathrm{AE}$, but many research gaps remain

- This summary highlights treatment for which there is reasonable evidence of benefit, and those for which there is reasonable evidence of no benefit

- Future research priorities that have no current RCT evidence include the role of allergy testing (followed by allergen avoidance), and modified bathing habits in the management of $A E$ 
Summary (Abstract)

46

Atopic eczema (AE) is a common chronic inflammatory skin condition. Whilst many AE treatment options are available, the evidence to support their efficacy varies in depth and quality. In 2000, an NIHR HTA systematic review identified and evaluated existing randomised controlled trials (RCTs) of AE treatments. To ensure continuing utility, the NIHR commissioned an update to the review. Here, we present an overview of the updated report and key findings.

52

Systematic reviews and RCTs of AE treatments that included participants with AE (criteria based or diagnosed) were identified using: MEDLINE, EMBASE, CENTRAL, LILACS, AMED, CINAHL and Cochrane Skin Group Specialised Register (searched to August 31 2013 (RCTs) and 31 ${ }^{\text {st }}$ December 2015 (systematic reviews)). Outcome measures included: symptoms, AE severity, quality-of-life, and adverse effects. Study quality was assessed using the Cochrane Collaboration risk of bias tool.

Of the 287 new RCTs identified, only $22(8 \%)$ were judged to be low risk of bias. When combined with RCTs from the previous review ( $n=254$ ), we found 'reasonable evidence of benefit' for corticosteroids, calcineurin inhibitors, Atopiclair ${ }^{\top \mathrm{M}}$, ciclosporin, azathioprine, ultraviolet light and education programmes. Interventions with reasonable evidence of "no benefit' included some dietary interventions, ion exchange water softeners, multiple daily applications of topical corticosteroids and antibiotic-containing corticosteroids for non-infected AE. Many common treatments lack evidence of efficacy and warrant further evaluation. were used to establish the Global Resource of Eczema Trials (GREAT) Database. 


\section{Introduction}

Atopic eczema (AE) (syn. atopic dermatitis), is a chronic inflammatory skin condition characterised by an itchy red rash that affects all age groups ${ }^{1}$. AE has one of the highest burdens compared to other skin diseases. ${ }^{2}$

The evidence-base for AE treatments is extensive, but has limitations in terms of quality and relevance. ${ }^{3}$ This is exemplified by the 'Systematic Review of Treatments for Atopic Eczema', published by the National Institute for Health Research (NIHR), which identified 254 RCTs of AE treatment covering 47 interventions. ${ }^{4}$ The encompassing nature of the review, and critical appraisal of the evidence therein, has helped to inform clinical guidelines on an international level for over a decade and the report has been heavily cited, with more than 650 citations listed in Google Scholar at time of writing. ${ }^{5-8}$

To ensure its continuing utility, the NIHR commissioned an update of the systematic scoping review as part of a programme of work on the prevention and treatment of skin disease, ${ }^{9}$ with the aim of summarising the evidence-base for AE treatments for guideline writers, healthcare professionals and patients. This review will also help in identifying research gaps to be addressed in the future, and in identifying topics suitable for specific targeted systematic reviews. 
Methods used for the scoping review

The following section briefly described the methodology employed to create the scoping review, which can be viewed in its entirety in the methods section of the full report. ${ }^{9}$

\section{Design}

This was a systematic scoping review of all systematic reviews and randomised controlled trials (RCTs) for AE treatments. A scoping review attempts to systematically map existing evidence on a given topic and identify potential gaps in the literature to inform future research priorities. It differs from a clinically-focussed systematic review in that it often covers a much broader topic area, summarises the evidence in a qualitative format and offers limited critical appraisal. ${ }^{10}$

\section{Type of studies included}

As systematic reviews and RCTs represent the best source of unbiased evidence on the effectiveness of treatments, we only included these types of studies. Studies were required to contain at least one clinical outcome. Prevention studies, provocation studies, changes in blood biochemistry and evaluations of cellular mechanisms were excluded.

\section{Participants}

Studies were included if participants (of any age) had AE, as diagnosed by a physician, or that met with a diagnostic criteria (e.g. Hanifin and Rajka, ${ }^{11}$ UK working party ${ }^{12}$ or similar).

\section{Main outcome measures}

Outcome measures chosen for the review were deliberately broad, in order to reflect those commonly used in AE trials. ${ }^{13,14}$ Changes in patient-rated symptoms such as itching (pruritus) or sleep loss were extracted where possible. Global severity, as rated by patients or their physician, was also sought. Other outcomes included changes in AE severity rating scales; quality of life; and adverse events (encompassing adverse events and adverse reactions depending on how these were reported in the original RCTs).

\section{Search strategy}

We searched the following electronic databases (search dates end of 1999 to $31^{\text {st }}$ August 2013) - MEDLINE; EMBASE; CENTRAL; The Cochrane Skin Group Specialised Trials Register; Latin American and Caribbean Health Sciences database (LILACS); Allied and Complementary Medicine Database (AMED); Cumulative Index to Nursing and Allied Health Literature (CINAHL) (Supplementary Figure 1). We also searched www.controlledtrials.com for completed and ongoing RCTs using the terms atopic dermatitis, atopic eczema and eczema as well as using our extensive contacts in the field of AE research to identify other ongoing studies.

Systematic reviews on AE treatments were searched for up until Dec 2015 using PubMed, EMBASE, the Cochrane Library and NHS Evidence. Where appropriate the results of these specific systematic reviews are presented alongside the RCT evidence. 
124 We used the following disease terms for AE: atopic dermatitis, atopic eczema, eczema, neurodermatitis, infantile eczema, childhood eczema, or Besniers' prurigo. No language restrictions were applied; data from non-English papers was extracted by international colleagues. References were screened by one author (either SS or $\mathrm{HN}$ ), with discussion with a second author as required (HW, KT or SB). Those studies using terms that were definitely not $A E$, such as allergic contact eczema, were excluded. Terms that were considered possibly $A E$, such as 'childhood eczema', were scrutinised and only included if the description of the participants clearly indicated $\mathrm{AE}$.

\section{Data assessment and study quality}

132 Data was independently extracted by two authors (HN and SB or SS) with discrepancies resolved by consensus or by an arbitrator (HCW, KST or FMD). Although primarily a scoping review, trial quality (specifically randomisation, allocation concealment and blinding) was evaluated. This was done using Cochrane collaboration's risk of bias assessment tool. ${ }^{15}$ The overall risk of bias for the included studies was summarised according to defined criteria (Supplementary Table 1). Authors were not blinded to the identity of the RCT authors, and a more detailed quality assessment (such as GRADE ${ }^{16}$ ) was unfeasible given the number of included studies.

\section{Presentation of the results}

Results are presented according to broad categories of treatments: i) topical corticosteroids and topical immunomodulators; ii) emollients and other topical treatments (including bath additives and oils ); iii) antimicrobials including antibiotics, antiseptics and antifungals; iv) antihistamines and mast cell stabilisers; v) dietary interventions (including probiotics, essential fatty acids, vitamins, cows' milk substitutes); vi ) nonpharmacological interventions (including education, psychological therapies, different ways of providing AE care, allergen avoidance followed by allergen avoidance or re-introduction and medical devices); vi) phototherapy; vii) systemic immunomodulatory agents; viii) complementary therapies (homeopathy, aromatherapy, hypnotherapy, Chinese herbal medicine, St John's Wort, acupuncture, balneotherapy, relaxation); ix) other.

For clarity of interpretation, results are also summarised according to categories of evidence: treatments for which there is reasonable evidence of benefit treatments for which there is reasonable evidence of no-clinically useful benefit treatments for which there is insufficient evidence to inform clinical decision-making treatments with an absence of RCT evidence. authors based on availability and quality of the evidence, and the likelihood of clinically important effects. It is not intended to signify that all uncertainty has been resolved in those areas classed as having reasonable evidence of benefit or reasonable evidence of no benefit - simply that there is a reasonable body of evidence that may usefully inform clinical decision-making. In this paper, we have not tried to summarise the possible 
161 harms of all included studies, but harms and drawbacks of treatments are included for all treatment categories

162 in the main report.

Pooling of the trial results using meta-analysis was not possible due to the very wide nature of interventions included, and the very heterogeneous nature of study participants and outcomes. However, interventions with evidence of benefit or evidence of no benefit have been mapped to the latest relevant systematic reviews on these topics where they exist.

Results of the review

170 In addition to the 254 RCTs identified in the original 2000 scoping review, this updated includes an additional 171287 new RCTs, making 541 RCTs in total covering 92 different interventions for treating AE. The number of 172 RCTs published according to broad treatment categories is shown (Figure 1), with further details provided in 173 Supplementary Figure 2.

175 The size of the newly identified RCTs varied widely from seven randomised participants to 972

176 participants. Most of the trials were conducted in secondary care, and tended to include participants 177 with either moderate to severe disease, or mild to moderate disease. Very few RCTs included all 178 severities of $\mathrm{AE}$.

179 Reporting was generally poor, with "unclear" categories dominating the assessments: randomisation method 180 ( $2 \%$ high, $36 \%$ low and $62 \%$ unclear risk of bias), allocation concealment (3\% high, $15 \%$ low and $82 \%$ unclear 181 risk of bias), and blinding or masking of the intervention (15\% high, $28 \%$ low, $57 \%$ unclear risk of bias). Only $22 / 287(8 \%)$ were considered to be at low risk of bias for all three quality criteria (randomisation, allocation concealment and blinding). Overall agreement between the team members on the availability and quality of the evidence, and the likelihood of clinically important effects was good. 


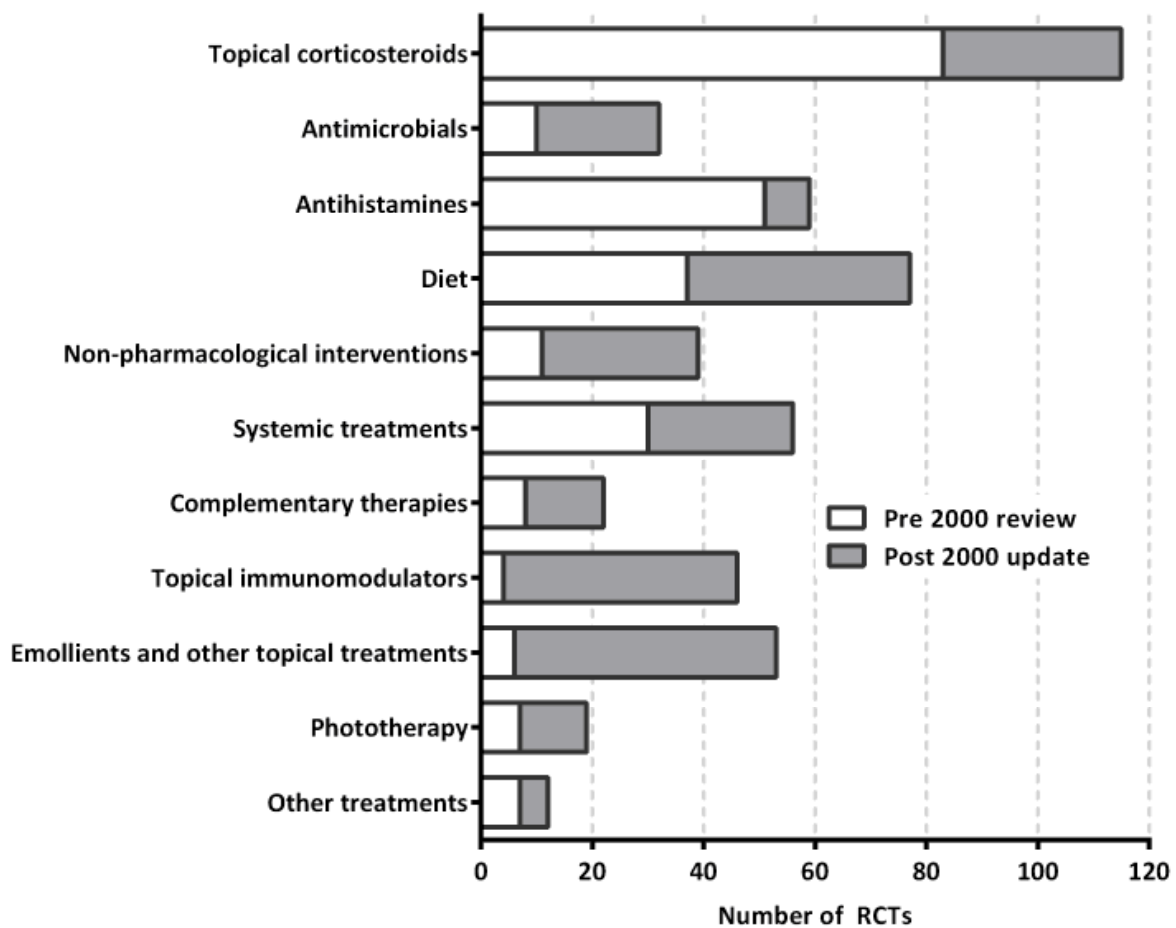

Figure 1: Number of included RCTs per treatment category

\section{Treatments with reasonable evidence of benefit}

Fourteen interventions or treatment approaches were felt to have reasonable evidence of benefit (Table 1). These include the use of topical corticosteroids and topical calcineurin inhibitors, both for the treatment of active $A E$, and as intermittent proactive (maintenance) therapy for the prevention of $A E$ flares. Other interventions including Atopiclair ${ }^{\mathrm{TM}}$ emollient, ultraviolet light therapy, azathioprine and ciclosporin, all had reasonable evidence of benefit compared to placebo/vehicle. Similarly, RCT and systematic review evidence suggested that education may be beneficial, although the exact components of a successful education programme in different clinical settings is still unclear.

Of the 14 interventions with reasonable evidence of benefit, 10/14 (71\%) have been the subject of more detailed, treatment-specific systematic reviews (Table 1).

\section{Treatments with evidence of no clinically useful benefit}

Nine interventions were deemed to have a reasonable level of evidence of no benefit in treating $A E$ (Table 2): topical corticosteroids containing an antibiotic for the treatment of AE that is not infected; Mycobacterium vaccae vaccine; probiotics; ion exchange water softeners; evening primrose oil and borage oil. 

research is required (Table 3). Some of the treatments have been trialled many times, however, the quality of reporting means that evidence for these treatments is not yet strong enough.

211 Treatments with an absence of RCT evidence

212 The scoping review has helped to identify areas for which there is currently no RCT evidence for commonly 213 used practices for the treatment of AE including: dilution of topical corticosteroids, order of application of 214 topical corticosteroids and emollients, impregnated bandages (zinc or ichthammol paste bandages), modified 215 bathing habits (non-antiseptic bath additives, soap avoidance, frequency of bathing), and the role of routine allergy testing followed by allergen avoidance or re-introduction. 


\section{Discussion}

\section{Main findings}

The systematic scoping review findings indicated there were only a small number of treatments with evidence of benefit (Table 1) and some treatments with evidence of no benefit (Table 2). For the majority of treatments, however, further but better designed research is needed (see Table 3). It is disappointing that there was a lack of strong evidence base for some of the most widely used AE treatments, such as emollients and bandages. However, stopping or restricting the use of these treatments on the basis of lack of RCT evidence would not benefit patients. Although information on treatment drawbacks and harms are included for each intervention in the main review, we have not tried to summarise them in this report due to their diverse and treatmentspecific nature. Generally, harms were reported less well than treatment benefits resulting in an asymmetry of information to inform patient choices.

In addition to the established approach for treating AE flares with topical corticosteroids, perhaps the single largest advance in AE treatment since the 2000 review has been the strong evidence supporting the value of a proactive approach for maintaining AE remission through the use of twice weekly topical corticosteroids or calcineurin inhibitors. ${ }^{17}$ Educational approaches have also emerged as a potentially promising intervention, although further work is needed to establish the most important components of the intervention, and the most cost-effective ways of delivering education in different health settings.

The finding that Atopiclair ${ }^{\mathrm{TM}}$ emollient has emerged as a potentially useful intervention for $\mathrm{AE}$ in four out of five industry-sponsored trials is difficult to interpret at this time. High-quality, independent trials are now needed that compare Atopiclair ${ }^{\mathrm{TM}}$ to other commonly used (and cheaper) emollients.

The understanding that some interventions now have sufficient evidence to suggest little or no benefit for $A E$ patients is equally important. These interventions provide options for disinvestment, ensuring that available funds are channelled to the most effective treatments. Possible areas to consider for disinvestment include: the application of topical corticosteroids twice a day, as once-daily application has been shown to be equally effective; topical corticosteroids containing antibiotics when used for the management of non-infected AE; use of ion exchange water softeners; and dietary supplements (probiotics, borage oil, evening primrose oil).

\section{Implications for research}

There is a lack of AE treatment trials conducted in a primary care setting, where most patients are seen. The research questions being investigated often fail to reflect the most pressing questions for clinicians and patients. A recent James Lind Alliance Priority Setting Partnership ${ }^{3}$ identified the most important treatment uncertainties as judged by patients and clinicians. When set in the context of the updated evidence base from the review, the following areas identified from the Priority Setting Partnership seem to be most pressing:

\section{Priority areas with no current RCT evidence}

- What role might allergy tests play in treating AE?

- What is the best way for people with AE to wash? 
- Which should be applied first when treating AE - emollients or topical corticosteroids?

255

256

257

258

259

260

261

262

263

264

265

266

267

268

269

270

271

272

273

274

275

276

277

278

279

280

281

282

283

284

285

286

287

288

289

290

291

\section{Priority areas with limited RCT evidence}

- What is the best and safest way of using topical corticosteroids for AE?

- What is the long-term safety of applying topical steroids to the skin for AE?

- Which emollient is the most effective and safe in treating AE?

- What is the best psychological treatment for itching/scratching in AE?

- What are the best and safest 'natural' products to apply to the skin?

- How much does avoidance of irritants and allergens help people with AE?

- What is the role of diet in treating AE (exclusion diets and nutritional supplements) care of multi-disciplinary teams? proactive flare prevention)?

- How effective are interventions to reduce skin infections in the management of AE?

- What is the best and safest way of using drugs that suppress the immune system (particularly in children) of emollient clinical and cost effectiveness (COMET: UKCRN ID 16571).

\section{Methodological research} beneficial for future clinical interpretation and evidence syntheses.

\section{Strengths and limitations of the review} required to detect rare treatment adverse effects.

- Which is more effective in the management of AE: education programmes, GP care, nurse-led care, dermatology-led

- Which is safer and more effective in treating AE: topical corticosteroids or calcineurin inhibitors (especially for

Some important topics have already been picked up by NIHR funding bodies, and large pragmatic trials are currently underway in the UK evaluating the role of topical and oral antibiotics for the treatment of infected AE (CREAM) (UKCRN ID 11233), silk clothing for the management of moderate to severe AE (CLOTHES) (UKCRN ID 15132), the role of bath emollients in the management of AE (BATHE: UKCRN ID 17348) and a feasibility trial

One of the most pressing concerns identified by this review is the continued preponderance of small, poorly reported and poorly conducted trials. Greater efforts to work collaboratively to conduct large, well designed studies that address important questions, can only be of benefit to patients and healthcare providers.

Similarly, the ability to combine study results in meta-analysis continues to be hampered by the wide variation in outcome measures used. The move towards using the same core outcome sets as encouraged by the Harmonising Outcome Measures for Eczema (HOME) initiative ${ }^{18-20}$ (www.homeforeczema.org) are likely to be

The updated review has used a clear methodology for identifying RCTs for inclusion, which has minimised potential selection bias. However, despite searching the main bibliographic databases (MEDLINE and EMBASE) and several smaller, specialist databases (CINAHL, AMED and LILACS), it is possible that we might have missed some RCTs. Many of the treatments that are lacking in RCT evidence have nevertheless been studied using uncontrolled designs, which may provide additional useful information. Similarly, large cohort studies are 
293 Whilst masking the identity of the trial authors from the review team was not practical, this may have 294 introduced bias when summarising qualitative aspects of the results. Given the very wide scope of the review and heterogeneous nature of participants, interventions and outcomes, it was not practical to undertake detailed meta-analysis for single interventions. These will need to be conducted (where appropriate) within much narrower intervention-specific systematic reviews in the future.

298

Our classification of treatment options into categories such as "evidence of benefit to support" is not tantamount to a positive recommendation for widespread use or otherwise, as that is the remit of guideline developers and depends on factors such as magnitude of benefit, adverse effects, how the treatment compares with existing active treatments, availability, cost effectiveness and population most likely to benefit.

As with all systematic reviews, the evidence presented will become out of date quite rapidly for some topics, and readers of the review are also directed to our free to access database of AE RCTs Global Resource of EczemA Trials (GREAT Database, accessible at http://www.greatdatabase.org.uk), which contains details of all the studies in the scoping review and can be used by readers who wish to investigate particular included or excluded studies further.

\section{Conclusion}

310 The number of RCTs for AE has increased substantially since the year $2000^{4}$ yet most are still small, poorly reported, and do not address questions of clinical importance to patients and healthcare professionals

312 We hope that our work provides an easily accessible guide for patients and clinicians wishing to research 313 treatment effects, and that it will be used by guideline developers to prevent duplication of effort in collating and evaluating the available evidence base for AE treatments. AE researchers will be able to identify potential research gaps and systematic reviews that require further work. 


\section{Table and figure legends}

320

Figure 1: Number of included RCTs per treatment category

321

322 Table 1: Treatments with reasonable evidence of benefit for AE patients

323 Table 2: Treatments with reasonable evidence of no benefit for AE patients

324 Table 3: Treatments which require more research

326 Supplementary Figure 1: Search strategy used to identify trials

327 Supplementary Table 1: Criteria used for discussing the risk of bias in the summaries of treatment categories 328 
Evidence of benefit: at least one good quality RCT or a large body of evidence and a clinically useful finding. We defined a 'good quality' trial as well designed

and well reported and with a magnitude of benefit deemed by the authors to be clinically relevant, and 'large body of evidence' as enough trials with consistent evidence of clinically relevant benefit, despite some limitations in reporting

\begin{tabular}{|c|c|c|c|c|c|}
\hline Intervention and severity of $\mathrm{AE}$ & Population & $\begin{array}{l}\text { Trials } \\
\text { (n) }\end{array}$ & $\begin{array}{l}\text { Participants } \\
\text { (n) }\end{array}$ & $\begin{array}{l}\text { Risk of } \\
\text { bias }\end{array}$ & Systematic Review(s) \\
\hline \multicolumn{6}{|l|}{ Topical Corticosteroids } \\
\hline $\begin{array}{l}\text { Corticosteroids (various strengths) are superior to vehicle } \\
\text { for } A E \text { of all severities }\end{array}$ & $\begin{array}{l}\text { Adults and } \\
\text { children }\end{array}$ & $23^{21-42}$ & 3857 & $\begin{array}{l}\text { Mostly } \\
\text { unclear }\end{array}$ & None \\
\hline \multicolumn{6}{|l|}{ Topical Calcineurin Inhibitors } \\
\hline $\begin{array}{l}\text { Pimecrolimus (1\%) is superior to vehicle for mild to } \\
\text { moderate } \mathrm{AE}\end{array}$ & $\begin{array}{l}\text { Mainly } \\
\text { children }\end{array}$ & $16^{43-57}$ & 3149 & $\begin{array}{l}\text { Mostly } \\
\text { unclear }\end{array}$ & $\begin{array}{l}\text { Chen }(2011)^{58} \\
\text { Number of included studies: } 6 \text { (<18 } \\
\text { years only) } \\
\text { Meta-analysis: OR } 3.21,95 \% \mathrm{Cl} \\
2.48 \text { to } 4.14\end{array}$ \\
\hline $\begin{array}{l}\text { Tacrolimus }(0.03,0.1,0.3 \%) \text { is superior to vehicle for } \\
\text { moderate to severe } \mathrm{AE}\end{array}$ & $\begin{array}{l}\text { Adults and } \\
\text { children }\end{array}$ & $9^{59-65}$ & 2089 & $\begin{array}{l}\text { Mostly } \\
\text { unclear }\end{array}$ & $\begin{array}{l}\text { Chen }(2011)^{58} \\
\text { Number of included studies: } 4(<18 \\
\text { years only) } \\
\text { Meta-analysis: OR } 4.56,95 \% \mathrm{Cl} \\
2.80 \text { to } 7.44\end{array}$ \\
\hline $\begin{array}{l}\text { Tacrolimus }(0.03,0.1 \%) \text { is superior to hydrocortisone } \\
\text { acetate }(1 \%) \text { for moderate-to severe } A E\end{array}$ & Children & $2^{66,67}$ & 1184 & Unclear & $\begin{array}{l}\text { Martins }(2015)^{68} \\
\text { Number of included studies: } 2 \\
\text { Tacrolimus } 0.03 \% \text { : RR } 2.58,95 \% \mathrm{Cl} \\
1.96 \text { to } 3.38 \\
\text { Number of included studies: } 1 \\
\text { Tacrolimus } 1 \% \text { : RR } 3.09,95 \% \mathrm{Cl} \\
2.14 \text { to } 4.45\end{array}$ \\
\hline $\begin{array}{l}\text { Tacrolimus }(0.1 \%) \text { superior to fluticasone propionate } \\
\text { ointment }(0.005 \%) \text { for moderate to severe facial } A E\end{array}$ & Adults & $1^{69}$ & 568 & $\begin{array}{l}\text { Mostly } \\
\text { unclear }\end{array}$ & Not applicable \\
\hline $\begin{array}{l}\text { Tacrolimus }(0.1,0.03 \%) \text { is superior to pimecrolimus }(1 \%) \text { for } \\
\text { AE of all severities }\end{array}$ & $\begin{array}{l}\text { Adults and } \\
\text { children }\end{array}$ & $5^{70-72 *}$ & 1243 & Mostly low & $\begin{array}{l}\text { Martins }(2015)^{68} \\
\text { Number of included studies: } 3 \\
\text { Meta-analysis: RR } 1.80,95 \% \mathrm{Cl} \\
1.35 \text { to } 2.42\end{array}$ \\
\hline \multicolumn{6}{|l|}{$\begin{array}{l}\text { Proactive (maintenance) topical therapy for preventing } \\
\text { flares }\end{array}$} \\
\hline $\begin{array}{l}\text { Corticosteroids applied twice a week are superior to vehicle } \\
\text { for moderate to severe } A E\end{array}$ & $\begin{array}{l}\text { Adults and } \\
\text { children }\end{array}$ & $4^{73-76}$ & 929 & $\begin{array}{l}\text { Mostly } \\
\text { unclear }\end{array}$ & $\begin{array}{l}\text { Schmitt }(2011)^{17} \\
\text { Number of included studies: } 4 \\
\text { Meta-analysis: RR } 0.46,95 \% \mathrm{Cl} \\
0.38-0.55\end{array}$ \\
\hline $\begin{array}{l}\text { Tacrolimus }(0.1,0.03 \%) \text { applied twice a week is superior to } \\
\text { vehicle for mild to severe AE }\end{array}$ & $\begin{array}{l}\text { Adults and } \\
\text { children }\end{array}$ & $4^{77-80}$ & 741 & $\begin{array}{l}\text { Mostly } \\
\text { unclear }\end{array}$ & $\begin{array}{l}\text { Schmitt }(2011)^{17} \\
\text { Number of included studies: } 3 \\
\text { Meta-analysis: RR } 0.78,95 \% \mathrm{Cl} \\
0.60-1.00\end{array}$ \\
\hline $\begin{array}{l}\text { Pimecrolimus ( } 1 \% \text { ) applied twice a week is superior to } \\
\text { vehicle for AE of all severities }\end{array}$ & $\begin{array}{l}\text { Mainly } \\
\text { children }\end{array}$ & $2^{44,81}$ & 251 & Mostly low & None \\
\hline \multicolumn{6}{|l|}{ Systemic Therapies } \\
\hline Ciclosporin superior to placebo for severe $\mathrm{AE}$ & Adults & $4^{82-85}$ & 113 & $\begin{array}{l}\text { Mostly } \\
\text { unclear }\end{array}$ & $\begin{array}{l}\text { Schmitt } 2007^{86} \\
\text { Number of included studies: } 12 \\
\text { Meta-analysis: Included non-RCTs }\end{array}$ \\
\hline Azathioprine superior to placebo for moderate to severe $\mathrm{AE}$ & Adults & $2^{87,88}$ & 100 & Mostly low & $\begin{array}{l}\text { Schram } 2011^{89} \\
\text { Number of included studies: } 2 \\
\text { Meta-analysis: not done }\end{array}$ \\
\hline \multicolumn{6}{|l|}{ Ultra-violet Light Therapy } \\
\hline $\begin{array}{l}\text { NB-UVB superior to placebo (visible light) for moderate to } \\
\text { severe AE }\end{array}$ & Adults & $2^{90,91}$ & 116 & $\begin{array}{l}\text { Mostly } \\
\text { unclear }\end{array}$ & $\begin{array}{l}\text { Dogra } 2015^{92} \\
\text { Number of included studies: } 13 \\
\text { (included non-RCTs) } \\
\text { Meta-analysis: not done } \\
\text { Gambichler } 2005^{93} \\
\text { Number of included studies: } 3 \\
\text { (included non-RCTs) } \\
\text { Meta-analysis: not done }\end{array}$ \\
\hline \multicolumn{6}{|l|}{ Other } \\
\hline Atopiclair $^{T M}$ superior to vehicle for mild to moderate $A E$ & $\begin{array}{l}\text { Adults and } \\
\text { children }\end{array}$ & $4^{94-98}$ & 489 & Mixed & None \\
\hline $\begin{array}{l}\text { Education superior to no-education for moderate to severe } \\
A E\end{array}$ & $\begin{array}{l}\text { Mainly } \\
\text { children }\end{array}$ & $7^{99-105}$ & 1076 & Mixed & $\begin{array}{l}\text { Ersser } 2014106 \\
\text { Number of included studies:10 } \\
\text { Meta-analysis: not done }\end{array}$ \\
\hline
\end{tabular}

Table 1: Treatments with reasonable evidence of benefit for AE patients Meta-analysis: not done 
Evidence of no benefit: at least one good quality RCT or several less well reported RCTs which consistently failed to show a convincing benefit on overall disease activity. We defined a 'good quality' trial as well designed and well reported, and large enough to exclude a clinically useful benefit or several trials with no evidence of benefit to give confidence in there being no clinically relevant benefit, despite less clear reporting

\begin{tabular}{|c|c|c|c|c|c|}
\hline Intervention and severity of $\mathrm{AE}$ & Population & Trials (n) & $\begin{array}{l}\text { Participants } \\
\text { (n) }\end{array}$ & $\begin{array}{l}\text { Risk of } \\
\text { bias }\end{array}$ & Systematic Review(s) \\
\hline $\begin{array}{l}\text { Twice daily versus once daily topical } \\
\text { corticosteroids }\end{array}$ & Adults and children & $3^{34,107,108}$ & 617 & $\begin{array}{l}\text { Mostly } \\
\text { unclear }\end{array}$ & $\begin{array}{l}\text { Green }(2005)^{109} \\
\text { Number of included studies: } 10 \\
\text { Meta-analysis: not preformed (heterogeneity) }\end{array}$ \\
\hline $\begin{array}{l}\text { Antibiotic-containing corticosteroids } \\
\text { versus corticosteroids alone for mild } \\
\text { to severe non-infected AE }\end{array}$ & Mainly unspecified & $5^{110-114}$ & 352 & $\begin{array}{l}\text { Mostly } \\
\text { unclear }\end{array}$ & $\begin{array}{l}\text { Bath-Hextall (2010) }{ }^{115} \\
\text { Number of included studies: } 2 \\
\text { Meta-analysis: RR } 0.52,95 \% \mathrm{Cl} 0.23 \text { to } 1.16\end{array}$ \\
\hline $\begin{array}{l}\text { Probiotics for treating AE versus } \\
\text { placebo }\end{array}$ & Mainly children & $20^{116-135}$ & 1513 & $\begin{array}{l}\text { Mostly } \\
\text { unclear }\end{array}$ & $\begin{array}{l}\text { Boyle (2009) }{ }^{136} \\
\text { Number of included studies: } 5 \\
\text { Meta-analysis: mean difference }-0.90,95 \% \mathrm{Cl} \text { - } \\
2.84 \text { to } 1.04\end{array}$ \\
\hline $\begin{array}{l}\text { Dietary supplements rich in linoleic } \\
\text { acid (evening primrose oil and borage } \\
\text { oil) versus placebo }\end{array}$ & Mainly adults & $23^{137-158}$ & 1448 & $\begin{array}{l}\text { Mostly } \\
\text { unclear }\end{array}$ & $\begin{array}{l}\text { Bamford (2013) } 159 \\
\text { Number of included studies: evening primrose } \\
\text { oil ( } 7 \text { trials) } \\
\text { Meta-analysis for Evening Primrose Oil mean } \\
\text { difference }-2.22,95 \% \mathrm{Cl}-10.48 \text { to } 6.04 \text {. } \\
\text { Number of included studies: borage oil ( } 8 \text { trials) } \\
\text { Meta-analysis for borage oil: not preformed } \\
\text { (heterogeneity) }\end{array}$ \\
\hline $\begin{array}{l}\text { Protease inhibitor SRD441 versus } \\
\text { vehicle in for mild to moderate } A E\end{array}$ & Adults & $1^{160}$ & 93 & Mostly low & SR not applicable \\
\hline $\begin{array}{l}\text { Emollient with furfuryl palmitate } \\
\text { versus emollient alone for mild to } \\
\text { moderate } \mathrm{AE}\end{array}$ & Children & $1^{161}$ & 117 & Low & SR not applicable \\
\hline $\begin{array}{l}\text { Ion exchange water softening devices } \\
\text { versus no water softening for } \\
\text { moderate to severe } A E\end{array}$ & Children & $1^{162}$ & 336 & Low & SR not applicable \\
\hline Cipamfylline cream versus vehicle & Adults & $1^{163}$ & 103 & Mostly low & SR not applicable \\
\hline $\begin{array}{l}\text { Mycobacterium vaccae vaccine } \\
\text { versus no vaccine for moderate to } \\
\text { severe } A E\end{array}$ & Mainly children & $4^{164-167}$ & 372 & Low & None \\
\hline
\end{tabular}




\begin{tabular}{|c|c|c|}
\hline Intervention & $\begin{array}{l}\text { Number } \\
\text { of trials }\end{array}$ & $\begin{array}{l}\text { Number of } \\
\text { participants }\end{array}$ \\
\hline Emollients & $20^{168-186}$ & 1664 \\
\hline Dietary interventions including prebiotics, dietary restrictions, and synbiotics & $13^{187-199}$ & 711 \\
\hline $\begin{array}{l}\text { Non-pharmacological interventions, including: specialised clothing (silk or synthetic fibres with or without antibiotics); } \\
\text { environmental interventions (house dust mite reduction, desensitisation); staying in a different climate; different approaches } \\
\text { to organisation of care such as additional visits to the doctors or nurse led clinics; support groups; e-health management; } \\
\text { psychological therapies (stress reduction or habit reversal techniques); balneotherapy (salt baths); biofeedback }\end{array}$ & $33^{200-232}$ & 2447 \\
\hline Oral antibiotics for clinically infected or uninfected $\mathrm{AE}$ & $3^{233-235}$ & 125 \\
\hline Topical corticosteroids combined with topical antibiotics for infected $\mathrm{AE}$ & $2^{110,236}$ & 660 \\
\hline Wet wraps in addition to topical corticosteroids & $5^{237-241}$ & 153 \\
\hline Antiseptic and non-antiseptic bath additives & $4^{242-245}$ & 97 \\
\hline Systemic and topical antifungals & $4^{246-249}$ & 202 \\
\hline $\begin{array}{l}\text { Topical treatments including: topical vitamin B12; topical coal tar; camellia oil; SRD441 (protease inhibitor); WBI-1001 (an } \\
\text { inhibitor of T cell inflammatory cytokine secretion); hippophe rhamnoides; black seed oil; pill mask; rosmarinic acid; } \\
\text { vitreoscilla filiformis; shale oil; miltefosine; opiate receptor antagonist; carbohydrate derived fulvic acid; raffinose; farnesol } \\
\text { and xylitol, bacterial antigens; camomile extract; heparin and levomenol; 15(R/S)-Methyl-lipoxin A4, N-acetyl-I- } \\
\text { hydroxyproline; nalmefene hydrochloride monohydrate (SRD174) }\end{array}$ & $27^{250-276}$ & 1340 \\
\hline $\begin{array}{l}\text { Systemic treatments including: oral prednisolone; methotrexate; mycophenolate mofetil; biological therapies (omalizumab; } \\
\text { mepolizumab); intravenous immunoglobulin; montelukast }\end{array}$ & $22^{277-298}$ & 900 \\
\hline Oral antihistamines & $\begin{array}{l}29^{297,299-} \\
326\end{array}$ & 4201 \\
\hline $\begin{array}{l}\text { Other less commonly used interventions including: oral pimecrolimus; oral naltrexone; autologous blood therapy; } \\
\text { tandospirone citrate; full spectrum light therapy; excimer laser; nitrazepam; theophylline; topical salbutamol; papaverine and } \\
\text { suplatast tosilate }\end{array}$ & $14^{327-338}$ & 481 \\
\hline $\begin{array}{l}\text { Complementary therapies including: Chinese Herbal treatment; hypnotherapy; massage therapy; aromatherapy; acupuncture; } \\
\text { acupressure; and other herbal treatments }\end{array}$ & $17^{339-354}$ & 604 \\
\hline
\end{tabular}


Friedmann PS \& Holden CA. in Rook's Textbook of Dermatology (eds Burns DA, Braethnach SM, Cox N, \& Griffiths CE) (Blackwell Publishers, 2004).

Hay, R. J. et al. The global burden of skin disease in 2010: an analysis of the prevalence and impact of skin conditions. The Journal of investigative dermatology 134, 1527-1534, doi:10.1038/jid.2013.446 (2014).

Batchelor, J. M. et al. The Eczema Priority Setting Partnership: a collaboration between patients, carers, clinicians and researchers to identify and prioritize important research questions for the treatment of eczema. $\mathrm{Br} J$ Dermatol 168, 577-582, doi:10.1111/bjd.12040 (2013).

Hoare, C., Li Wan Po, A. \& Williams, H. Systematic review of treatments for atopic eczema. Health Technol Assess 4, 1-191 (2000).

NICE. in Atopic Eczema in Children: Management of atopic eczema in children from birth up to the age of 12 years NICE Guidance (2007).

SIGN. Scottish Intercollegiate Guidelines Network. Management of atopic eczema in primary care. . SIGN publication no. 125 (2011).

Katayama, I. et al. Japanese Guideline for Atopic Dermatitis 2014. Allergology international : official journal of the Japanese Society of Allergology 63, 377-398, doi:10.2332/allergolint.14-RAI-0769 (2014).

Sidbury, R. et al. Guidelines of care for the management of atopic dermatitis: Section 4. Prevention of disease flares and use of adjunctive therapies and approaches. Journal of the American Academy of Dermatology 71, 1218-1233, doi:10.1016/j.jaad.2014.08.038 (2014).

Nankervis, H. et al. Scoping systematic review of treatments for eczema. 4, doi:10.3310/pgfar04070 (2016). Armstrong, R., Hall, B. J., Doyle, J. \& Waters, E. Cochrane Update. 'Scoping the scope' of a cochrane review. Journal of public health (Oxford, England) 33, 147-150, doi:10.1093/pubmed/fdr015 (2011). Hanifin, J. M. \& Rajka, G. Diagnostic Features of Atopic-Dermatitis. Acta Derm-Venereol 92, $44-47$ (1980). Williams, H. C. et al. The U.K. Working Party's Diagnostic Criteria for Atopic Dermatitis. I. Derivation of a minimum set of discriminators for atopic dermatitis. Br J Dermatol 131, 383-396 (1994).

Rehal, B. \& Armstrong, A. W. Health outcome measures in atopic dermatitis: a systematic review of trends in disease severity and quality-of-life instruments 1985-2010. PloS one 6, e17520, doi:10.1371/journal.pone.0017520 (2011).

Schmitt, J., Langan, S., Williams, H. C. \& European Dermato-Epidemiology Network. What are the best outcome measurements for atopic eczema? A systematic review. The Journal of allergy and clinical immunology 120, 13891398, doi:10.1016/j.jaci.2007.08.011 (2007).

Higgins, J. \& Green, S. Cochrane Handbook for Systematic Reviews of Interventions < www.cochranehandbook.org> (2011).

Atkins, D. et al. Grading quality of evidence and strength of recommendations. BMJ (Clinical research ed.) 328, 1490, doi:10.1136/bmj.328.7454.1490 (2004).

Schmitt, J., von Kobyletzki, L., Svensson, A. \& Apfelbacher, C. Efficacy and tolerability of proactive treatment with topical corticosteroids and calcineurin inhibitors for atopic eczema: systematic review and meta-analysis of randomized controlled trials. Br J Dermatol 164, 415-428, doi:10.1111/j.1365-2133.2010.10030.x (2011). Schmitt, J. et al. Towards global consensus on outcome measures for atopic eczema research: results of the HOME II meeting. Allergy 67, 1111-1117, doi:10.1111/j.1398-9995.2012.02874.x (2012).

Chalmers, J. R. et al. Report from the third international consensus meeting to harmonise core outcome measures for atopic eczema/dermatitis clinical trials (HOME). Br J Dermatol 171, 1318-1325, doi:10.1111/bjd.13237 (2014).

Spuls, P. Report from the fourth international consensus meeting to harmonise core outcome measures for atopic eczema/dermatitis clinical trials (HOME initiative) (at peer review). (2016).

1 Paller, A. S. et al. Fluocinolone acetonide $0.01 \%$ in peanut oil: therapy for childhood atopic dermatitis, even in patients who are peanut sensitive. Journal of the American Academy of Dermatology 48, 569-577 (2003). Eichenfield, L. F., Miller, B. H. \& Cutivate Lotion Study, G. Two randomized, double-blind, placebo-controlled studies of fluticasone propionate lotion $0.05 \%$ for the treatment of atopic dermatitis in subjects from 3 months of age. Journal of the American Academy of Dermatology 54, 715-717 (2006).

Hebert, A. A. et al. Safety and efficacy of desonide hydrogel $0.05 \%$ in pediatric subjects with atopic dermatitis. Journal of drugs in dermatology : JDD 6, 175-181 (2007).

Pellanda, C., Weber, M., Bircher, A. \& Surber, C. Low-dose triamcinolone acetonide in the phytocosmetic lichtena reduces inflammation in mild to moderate atopic dermatitis. Dermatology (Basel, Switzerland) 211, 338-340 (2005).

Abramovits, W. \& Oquendo, M. Hydrocortisone butyrate $0.1 \%$ lipocream in pediatric patients with atopic dermatitis. Skinmed, $72-79$ (2010).

<http://www.mrw.interscience.wiley.com/cochrane/clcentral/articles/219/CN-00749219/frame.html>. Matheson, R. et al. Hydrocortisone butyrate $0.1 \%$ lotion in the treatment of atopic dermatitis in pediatric subjects. Journal of drugs in dermatology : JDD 7, 266-271 (2008).

Del Rosso, J. Q., Bhambri, S., Del Rosso, J. Q. \& Bhambri, S. Daily application of fluocinonide $0.1 \%$ cream for the treatment of atopic dermatitis. The Journal of Clinical \& Aesthetic Dermatology 2, 24-32 (2009). 
Breneman, D. et al. Clobetasol propionate $0.05 \%$ lotion in the treatment of moderate to severe atopic dermatitis: a randomized evaluation versus clobetasol propionate emollient cream. Journal odf Drugs in Dermatology 4, 330336 (2005).

Woods, M. T., Brown, P. A., Baig-Lewis, S. F. \& Simpson, E. L. Effects of a novel formulation of fluocinonide $0.1 \%$ cream on skin barrier function in atopic dermatitis. Journal of drugs in dermatology : JDD 10 (2), $171-176$ (2011). Brock, W. \& Cullen, S. I. Triamcinolone acetonide in flexible collodion for dermatologic therapy. Archives of Dermatology 96, 193-194 (1967).

Gehring, W. \& Gloor, M. Treatment of the atopic dermatitis with a water-in-oil emulsion with or without the addition of hydrocortisone - Results of a controlled double-blind randomized study using clinical evaluation and bioengineering methods. [German]. H+G Zeitschrift fur Hautkrankheiten 71 (7), 554-560 (1996).

Vanderploeg, D. E. Betamethasone dipropionate ointment in the treatment of psoriasis and atopic dermatitis: a double blind study. Southern Medical Journal 69 (7), 862-863 (1976).

Roth, H. L. \& Brown, E. P. Hydrocortisone valerate. Double-blind comparison with two other topical steroids. Cutis 21 (5), 695-698 (1978).

Sudilovsky, A., Muir, J. G. \& Bocobo, F. C. A comparison of single and multiple applications of halcinonide cream. International Journal of Dermatology 20 (9), 609-613 (1981).

Lupton, E. S., Abbrecht, M. M. \& Brandon, M. L. Short-term topical corticosteroid therapy (halcinonide ointment) in the management of atopic dermatitis. Cutis; cutaneous medicine for the practitioner 30 (5), $671-675$ (1982). Sefton, J., Loder, J. S. \& Kyriakopoulos, A. A. Clinical evaluation of hydrocortisone valerate $0.2 \%$ ointment. Clinical Therapeutics 6 (3), 282-293 (1984).

Wahlgren, C. F., Hagermark, O., Bergstrom, R. \& Hedin, B. Evaluation of a new method of assessing pruritus and antipruritic drugs. Skin Pharmacology 1 (1), 3-13 (1988).

Stalder, J. F. et al. Local steroid therapy and bacterial skin flora in atopic dermatitis. British Journal of Dermatology 131, 536-540 (1994).

Lebwohl, M. Efficacy and safety of fluticasone propionate ointment, $0.005 \%$, in the treatment of eczema. Cutis; cutaneous medicine for the practitioner 57 (2 Suppl), 62-68 (1996).

Lebwohl, M. et al. A comparison of once-daily application of mometasone furoate $0.1 \%$ cream compared with twice-daily hydrocortisone valerate $0.2 \%$ cream in pediatric atopic dermatitis patients who failed to respond to hydrocortisone. International Journal of Dermatology 38, 604-606 (1999).

Sears, H. W., Bailer, J. W. \& Yeadon, A. Efficacy and safety of hydrocortisone buteprate $0.1 \% \mathrm{cream}$ in patients with atopic dermatitis. Clinical Therapeutics 19, 710-719 (1997).

Maloney, J. et al. Clobetasol propionate emollient $0.05 \%$ in the treatment of atopic dermatitis. International Journal of Dermatology 37 (2), 142-144 (1998).

Salavec, M. \& Buckova, H. First experiences with 1\% Pimecrolimus cream therapy in prevention of atopic eczema flares in children (Czechoslovakian). Cesko-slovenska dermatologie 79, 3-7 (2004).

Zuberbier, T. et al. Steroid-sparing effect of pimecrolimus cream $1 \%$ in children with severe atopic dermatitis. Dermatology (Basel, Switzerland) 215, 325-330 (2007).

Sigurgeirsson, B. et al. Effectiveness and safety of a prevention-of-flare-progression strategy with pimecrolimus cream $1 \%$ in the management of paediatric atopic dermatitis. Journal of the European Academy of Dermatology \& Venereology 22, 1290-1301 (2008).

Meurer, M. et al. Pimecrolimus cream in the long-term management of atopic dermatitis in adults: a six-month study. Dermatology 205, 271-277, doi:65863 (2002).

Gollnick, H. et al. Pimecrolimus cream 1\% in the long-term management of adult atopic dermatitis: prevention of flare progression. A randomized controlled trial. British Journal of Dermatology 158, 1083-1093 (2008).

Hoeger, P. H. et al. The treatment of facial atopic dermatitis in children who are intolerant of, or dependent on, topical corticosteroids: A randomized, controlled clinical trial. British Journal of Dermatology 160, 415-422, doi:http://dx.doi.org/10.1111/j.1365-2133.2008.08928.x (2009).

Murrell, D. F. et al. A randomized controlled trial of pimecrolimus cream $1 \%$ in adolescents and adults with head and neck atopic dermatitis and intolerant of, or dependent on, topical corticosteroids. Br J Dermatol 157, 954959 (2007).

Leung, D. Y. et al. Effects of pimecrolimus cream $1 \%$ in the treatment of patients with atopic dermatitis who demonstrate a clinical insensitivity to topical corticosteroids: a randomized, multicentre vehicle-controlled trial. British Journal of Dermatology 161, 435-443 (2009).

Ho, V. C. et al. Safety and efficacy of nonsteroid pimecrolimus cream $1 \%$ in the treatment of atopic dermatitis in infants. Journal of Pediatrics 142, 155-162 (2003).

Eichenfield, L. F. et al. Safety and efficacy of pimecrolimus (ASM 981) cream $1 \%$ in the treatment of mild and moderate atopic dermatitis in children and adolescents.[see comment]. Journal of the American Academy of Dermatology 46, 495-504 (2002).

Kaufmann, R. et al. Onset of pruritus relief with pimecrolimus cream $1 \%$ in adult patients with atopic dermatitis: a randomized trial. Allergy 61, 375-381 (2006).

Kaufmann, R. et al. Onset of action of pimecrolimus cream $1 \%$ in the treatment of atopic eczema in infants. Journal of Allergy and Clinical Immunology 114, 1183-1188 (2004). 
Fowler, J., Johnson, A., Chen, M. \& Abrams, K. Improvement in pruritus in children with atopic dermatitis using pimecrolimus cream 1\%. Cutis; cutaneous medicine for the practitioner 79, 65-72 (2007).

Leo, H. L., Bender, B. G., Leung, S. B., Tran, Z. V. \& Leung, D. Y. Effect of pimecrolimus cream $1 \%$ on skin condition and sleep disturbance in children with atopic dermatitis. Journal of Allergy and Clinical Immunology 114, 691-693 (2004).

Aschoff, R. et al. Skin physiological parameters confirm the therapeutic efficacy of pimecrolimus cream $1 \%$ in patients with mild-to-moderate atopic dermatitis. Experimental Dermatology 18, 24-29 (2009).

Chen, S. L., Yan, J. \& Wang, F. S. Two topical calcineurin inhibitors for the treatment of atopic dermatitis in pediatric patients: a meta-analysis of randomized clinical trials. The Journal of dermatological treatment 21, 144156, doi:10.3109/09546630903401470 (2010).

Paller, A., Eichenfield, L. F., Leung, D. Y., Stewart, D. \& Appell, M. A 12-week study of tacrolimus ointment for the treatment of atopic dermatitis in pediatric patients. Journal of the American Academy of Dermatology 44, S47-57 (2001).

Hanifin, J. M., Ling, M. R., Langley, R., Breneman, D. \& Rafal, E. Tacrolimus ointment for the treatment of atopic dermatitis in adult patients: part I, efficacy. Journal of the American Academy of Dermatology 44, S28-38 (2001). Chapman, M. S. et al. Tacrolimus ointment $0.03 \%$ shows efficacy and safety in pediatric and adult patients with mild to moderate atopic dermatitis. Journal of the American Academy of Dermatology 53, S177-185, doi:10.1016/j.jaad.2005.04.061 (2005).

Dou, X. et al. [The impact of tacrolimus ointment on health-related quality of life of Chinese adult and pediatric patients with atopic dermatitis]. Journal of Clinical Dermatology 35, 50-52 (2006).

Otsuki, M., Kawashima, M., Shibata, Y., Nakagawa, H. \& Harada, S. [Efficacy and Safety of FK506 (Tacrolimus) Ointment in Children with Atopic Dermatitis-Phase III Double-blinded Comparison with Vehicle Ointment]. Journal of Clinical Therapeutics and Medicines 19, 569-595 (2003).

Rahman, M. F. et al. Efficacy of topical tacrolimus in atopic dermatitis. Journal of Pakistan Association of Dermatologists 18, 84-92 (2008).

Granlund, H., Remitz, A., Kyllonen, H., Lauerma, A. I. \& Reitamo, S. Treatment of lichenified atopic eczema with tacrolimus ointment. Acta Derm-Venereol 81, 314-315 (2001).

Reitamo, S. et al. Efficacy and safety of tacrolimus ointment compared with that of hydrocortisone acetate ointment in children with atopic dermatitis. [see comment][summary for patients in Curr Allergy Asthma Rep. 2002 Jul;2(4):273-4; PMID: 12044259]. Journal of Allergy \& Clinical Immunology 109, 539-546 (2002).

Reitamo, S. et al. $0.03 \%$ Tacrolimus ointment applied once or twice daily is more efficacious than $1 \%$ hydrocortisone acetate in children with moderate to severe atopic dermatitis: results of a randomized doubleblind controlled trial.[see comment]. British Journal of Dermatology 150, 554-562 (2004).

Cury Martins, J. et al. Topical tacrolimus for atopic dermatitis. The Cochrane database of systematic reviews 7 , Cd009864, doi:10.1002/14651858.CD009864.pub2 (2015).

Doss, N. et al. Superiority of tacrolimus $0.1 \%$ ointment compared with fluticasone $0.005 \%$ in adults with moderate to severe atopic dermatitis of the face: results from a randomized, double-blind trial. British Journal of Dermatology 161, 427-434 (2009).

Paller, A. S. et al. Tacrolimus ointment is more effective than pimecrolimus cream with a similar safety profile in the treatment of atopic dermatitis: results from 3 randomized, comparative studies. Journal of the American Academy of Dermatology 52, 810-822, doi:10.1016/j.jaad.2004.12.038 (2005).

Kempers, S. et al. A randomized investigator-blinded study comparing pimecrolimus cream $1 \%$ with tacrolimus ointment $0.03 \%$ in the treatment of pediatric patients with moderate atopic dermatitis. Journal of the American Academy of Dermatology 51, 515-525, doi:10.1016/j.jaad.2004.01.051 (2004).

2 Draelos, Z. et al. Pharmacokinetics of topical calcineurin inhibitors in adult atopic dermatitis: a randomized, investigator-blind comparison. Journal of the American Academy of Dermatology 53, 602-609, doi:10.1016/j.jaad.2005.06.013 (2005).

3 Peserico, A. et al. Reduction of relapses of atopic dermatitis with methylprednisolone aceponate cream twice weekly in addition to maintenance treatment with emollient: a multicentre, randomized, double-blind, controlled study. Br J Dermatol 158, 801-807, doi:10.1111/j.1365-2133.2008.08436.x (2008).

4 Hanifin, J., Gupta, A. K. \& Rajagopalan, R. Intermittent dosing of fluticasone propionate cream for reducing the risk of relapse in atopic dermatitis patients. British Journal of Dermatology 147, 528-537 (2002).

Berth-Jones, J. et al. Twice weekly fluticasone propionate added to emollient maintenance treatment to reduce risk of relapse in atopic dermatitis: randomised, double blind, parallel group study. BMJ (Clinical research ed.) 326, 1367, doi:10.1136/bmj.326.7403.1367 (2003).

Glazenburg, E. J., Wolkerstorfer, A., Gerretsen, A. L., Mulder, P. G. \& Oranje, A. P. Efficacy and safety of fluticasone propionate $0.005 \%$ ointment in the long-term maintenance treatment of children with atopic dermatitis: differences between boys and girls? Pediatric allergy and immunology : official publication of the European Society of Pediatric Allergy and Immunology 20, 59-66 (2009).

Breneman, D. et al. Intermittent therapy for flare prevention and long-term disease control in stabilized atopic dermatitis: a randomized comparison of 3-times-weekly applications of tacrolimus ointment versus vehicle. Journal of the American Academy of Dermatology 58, 990-999 (2008). 
Thaci, D. et al. Proactive disease management with $0.03 \%$ tacrolimus ointment for children with atopic dermatitis: results of a randomized, multicentre, comparative study. British Journal of Dermatology 159, 13481356 (2008).

Wollenberg, A. et al. Proactive treatment of atopic dermatitis in adults with $0.1 \%$ tacrolimus ointment.[republished in Allergy. 2008 Jul;63(7):742-50; PMID: 18592619]. Allergy 63, 742-750 (2008) Takeuchi. A Randomized, Open-Label, Multicenter Trial of Topical Tacrolimus for the Treatment of Pruritus in Patients with Atopic Dermatitis. Annals of Dermatology (2012).

Bangert. Clinical and cytological effects of pimecrolimus cream $1 \%$ after resolution of active atopic dermatitis lesions by topical corticosteroids: A randomised controlled trial. Dermatology (2011).

Munro, C. S., Levell, N. J., Shuster, S. \& Friedmann, P. S. Maintenance treatment with cyclosporin in atopic eczema. Br J Dermatol 130, 376-380 (1994).

van Joost, T. et al. Cyclosporin in atopic dermatitis: a multicentre placebo-controlled study. Br J Dermatol 130, 634-640 (1994).

Sowden, J. M. et al. Double-blind, controlled, crossover study of cyclosporin in adults with severe refractory atopic dermatitis. Lancet (London, England) 338, 137-140 (1991).

Wahlgren, C. F., Scheynius, A. \& Hagermark, O. Antipruritic effect of oral cyclosporin A in atopic dermatitis. Acta Derm-Venereol 70, 323-329 (1990).

Schmitt, J., Schmitt, N. \& Meurer, M. Cyclosporin in the treatment of patients with atopic eczema - a systematic review and meta-analysis. Journal of the European Academy of Dermatology and Venereology : JEADV 21, 606619, doi:10.1111/j.1468-3083.2006.02023.x (2007).

Meggitt, S. J., Gray, J. C. \& Reynolds, N. J. Azathioprine dosed by thiopurine methyltransferase activity for moderate-to-severe atopic eczema: a double-blind, randomised controlled trial. Lancet (London, England) 367, 839-846, doi:10.1016/s0140-6736(06)68340-2 (2006).

Berth-Jones, J. et al. Azathioprine in severe adult atopic dermatitis: a double-blind, placebo-controlled, crossover trial. British Journal of Dermatology 147, 324-330 (2002).

Schram, M. E. et al. Off-label use of azathioprine in dermatology: a systematic review. Arch Dermatol 147, 474488, doi:10.1001/archdermatol.2011.79 (2011).

Jekler, J. \& Larko, O. UVB phototherapy of atopic dermatitis. Br J Dermatol 119, 697-705 (1988).

Reynolds, N. J., Franklin, V., Gray, J. C., Diffey, B. L. \& Farr, P. M. Narrow-band ultraviolet B and broad-band ultraviolet A phototherapy in adult atopic eczema: a randomised controlled trial. Lancet (London, England) 357, 2012-2016 (2001).

Dogra, S. \& Mahajan, R. Phototherapy for atopic dermatitis. Indian journal of dermatology, venereology and leprology 81, 10-15, doi:10.4103/0378-6323.148557 (2015).

Gambichler, T., Breuckmann, F., Boms, S., Altmeyer, P. \& Kreuter, A. Narrowband UVB phototherapy in skin conditions beyond psoriasis. Journal of the American Academy of Dermatology 52, 660-670, doi:10.1016/j.jaad.2004.08.047 (2005).

Patrizi, A. et al. A double-blind, randomized, vehicle-controlled clinical study to evaluate the efficacy and safety of MAS063DP (ATOPICLAIR) in the management of atopic dermatitis in paediatric patients. Pediatric Allergy \& Immunology 19, 619-625 (2008).

Boguniewicz, M. et al. MAS063DP is effective monotherapy for mild to moderate atopic dermatitis in infants and children: a multicenter, randomized, vehicle-controlled study. The Journal of pediatrics 152, 854-859 (2008). Abramovits, W., Boguniewicz, M. \& Adult Atopiclair Study, G. A multicenter, randomized, vehicle-controlled clinical study to examine the efficacy and safety of MAS063DP (Atopiclair) in the management of mild to moderate atopic dermatitis in adults. Journal of drugs in dermatology : JDD 5, 236-244 (2006).

Belloni, G., Pinelli, S. \& Veraldi, S. A randomised, double-blind, vehicle-controlled study to evaluate the efficacy and safety of MAS063D (Atopiclair) in the treatment of mild to moderate atopic dermatitis. European Journal of Dermatology 15, 31-36 (2005).

Miller, D. W. et al. An over-the-counter moisturizer is as clinically effective as, and more cost-effective than, prescription barrier creams in the treatment of children with mild-to-moderate atopic dermatitis: a randomized, controlled trial. J Drugs Dermatol 10, 531-537 (2011).

Span, L. et al. Intensive daycare for young adults with atopic eczema. Nederlands Tijdschrift voor Dermatologie \& Venereologie 11, 279-283 (2001).

Shaw, M., Morrell, D. S. \& Goldsmith, L. A. A study of targeted enhanced patient care for pediatric atopic dermatitis (STEP PAD). Pediatric Dermatology 25, 19-24 (2008).

Staab, D. et al. Age related, structured educational programmes for the management of atopic dermatitis in children and adolescents: multicentre, randomised controlled trial.[see comment]. BMJ (Clinical research ed.) 332, 933-938 (2006).

Staab, D. et al. Evaluation of a parental training program for the management of childhood atopic dermatitis. Pediatric allergy and immunology : official publication of the European Society of Pediatric Allergy and Immunology 13, 84-90 (2002).

Grillo, M., Gassner, L., Marshman, G., Dunn, S. \& Hudson, P. Pediatric atopic eczema: the impact of an educational intervention. Pediatric Dermatology 23, 428-436 (2006). 
Futamura M., M. I., Hayashi K., Ohya Y., Ito K. Effects of a short-term parental education program on childhood atopic dermatitis: A randomized controlled trial. Pediatric Dermatology, 438 - 443 (2013).

Kardorff, B. et al. Successful reduction of the SCORAD score by a short-time teaching method using a simplified skin model in children with atopic eczema in a 6-week comparison. Journal der Deutschen Dermatologischen Gesellschaft 1, 451-456 (2003).

Ersser, S. J. et al. Psychological and educational interventions for atopic eczema in children. The Cochrane database of systematic reviews 1, CD004054, doi:10.1002/14651858.CD004054.pub3 (2014).

Bleehen, S. S. et al. Fluticasone propionate $0.05 \%$ cream in the treatment of atopic eczema: A multicentre study comparing once-daily treatment and once-daily vehicle cream application versus twice-daily treatment. British Journal of Dermatology 133 (4), 592-597 (1995).

Koopmans, B., Lasthein, A. B., Mork, N. J., Austad, J. \& Suhonen, R. E. Multicentre randomized doulble-blind study of Locoid Lipocream fatty cream twice daily versus Locoid Lipocream once daily and Locobase once daily. Journal of Dermatological Treatment. 6, 103-106 (1995).

Green, C., Colquitt, J. L., Kirby, J. \& Davidson, P. Topical corticosteroids for atopic eczema: clinical and cost effectiveness of once-daily vs. more frequent use. Br J Dermatol 152, 130-141, doi:10.1111/j.13652133.2005.06410.x (2005).

Hung, S. H. et al. Staphylococcus colonization in atopic dermatitis treated with fluticasone or tacrolimus with or without antibiotics. Annals of allergy, asthma \& immunology : official publication of the American College of Allergy, Asthma, \& Immunology 98, 51-56 (2007).

Gong, J. Q. et al. Skin colonization by Staphylococcus aureus in patients with eczema and atopic dermatitis and relevant combined topical therapy: a double-blind multicentre randomized controlled trial. British Journal of Dermatology 155, 680-687 (2006).

Ravenscroft, J. C. et al. Short-term effects of topical fusidic acid or mupirocin on the prevalence of fusidic acid resistant (FusR) Staphylococcus aureus in atopic eczema. Br J Dermatol 148, 1010-1017 (2003).

Canpolat, F., Erkocoglu, M., Tezer, H., Kocabas, C. N., Kandi, B. Hydrocortisone acetate alone or combined with mupirocin for atopic dermatitis in infants under two years of age - a randomized double blind pilot trial. European Review for Medical \& Pharmacological Sciences (2012).

Schuttelaar, M. L. \& Coenraads, P. J. A randomized, double-blind study to assess the efficacy of addition of tetracycline to triamcinolone acetonide in the treatment of moderate to severe atopic dermatitis. Journal of the European Academy of Dermatology \& Venereology 22, 1076-1082 (2008).

Bath-Hextall, F. J., Birnie, A. J., Ravenscroft, J. C. \& Williams, H. C. Interventions to reduce Staphylococcus aureus in the management of atopic eczema: an updated Cochrane review. Br J Dermatol 163, 12-26 (2010).

Rosenfeldt, V. et al. Effect of probiotic Lactobacillus strains in children with atopic dermatitis. The Journal of allergy and clinical immunology 111, 389-395 (2003).

Sistek, D. et al. Is the effect of probiotics on atopic dermatitis confined to food sensitized children? Clinical \& Experimental Allergy 36, 629-633 (2006).

Cukrowska, B. et al. The influence of probiotic Lactobacillus casei and paracasei strains on clinical status of atopic eczema in children with food allergy on cow's milk proteins. [Polish]. Pediatria Wspolczesna. 10(2)(pp 67-70), 2008. Date of Publication: 2008.

Yesilova. Effect of Probiotics on the Treatment of Children with Atopic Dermatitis. Annals of Dermatology (2012). lemoli, E., Trabattoni, D., Parisotto, S., Borgonovo, L., Toscano, M., Rizzardini, G., Clerici, M., Ricci, E., Fusi, A., De Vecchi, E., Piconi, S., Drago, L., lemoli, Enrico, Trabattoni, Daria, Parisotto, Serena, Borgonovo, Linda, Toscano, Marco, Rizzardini, Giuliano, Clerici, Mario, Ricci, Elena, Fusi, Alessandra, De Vecchi, Elena, Piconi, Stefania, Drago, Lorenzo. Probiotics reduce gut microbial translocation and improve adult atopic dermatitis. Journal of Clinical Gastroenterology (2012).

Nermes, M., Kantele, J. M., Atosuo, T. J., Salminen, S. \& Isolauri, E. Interaction of orally administered Lactobacillus rhamnosus $\mathrm{GG}$ with skin and gut microbiota and humoral immunity in infants with atopic dermatitis. Clinical and Experimental Allergy 41 (3), 370-377, doi:http://dx.doi.org/10.1111/j.1365-2222.2010.03657.x.

Grüber, C. et al. Randomized, placebo-controlled trial of Lactobacillus rhamnosus GG as treatment of atopic dermatitis in infancy. Allergy 62, 1270-1276 (2007).

Brouwer, M. L. et al. No effects of probiotics on atopic dermatitis in infancy: a randomized placebo-controlled trial. Clinical \& Experimental Allergy 36, 899-906 (2006).

Folster-Holst, R. et al. Prospective, randomized controlled trial on Lactobacillus rhamnosus in infants with moderate to severe atopic dermatitis. British Journal of Dermatology 155, 1256-1261 (2006).

Viljanen, M. et al. Probiotics in the treatment of atopic eczema/dermatitis syndrome in infants: a double-blind placebo-controlled trial. Allergy 60, 494-500 (2005).

Moroi, M. et al. Beneficial effect of a diet containing heat-killed Lactobacillus paracasei $\mathrm{K} 71$ on adult type atopic dermatitis. Journal of Dermatology 38 (2), 131-139, doi:http://dx.doi.org/10.1111/j.1346-8138.2010.00939.x. Gobel, R., Larsen, N., Molgaard, C., Jakobsen, M. \& Michaelsen, K. F. Probiotics to young children with atopic dermatitis: A randomized placebo-controlled trial. International Journal of Probiotics and Prebiotics 5 (2), 53-59 (2010).

Woo, S. I., Kim, J. Y., Lee, Y. J., Kim, N. S. \& Hahn, Y. S. Effect of Lactobacillus sakei supplementation in children with atopic eczema-dermatitis syndrome. Annals of allergy, asthma \& immunology : official publication of the 
American College of Allergy, Asthma, \& Immunology, 343-348 (2010).

$<$ http://www.mrw.interscience.wiley.com/cochrane/clcentral/articles/516/CN-00742516/frame.html>. controlled trial. Arch Dis Child 90, 892-897, doi:10.1136/adc.2004.060673 (2005).

Torii, S. et al. Effects of oral administration of Lactobacillus acidophilus I-92 on the symptoms and serum markers of atopic dermatitis in children. International Archives of Allergy and Immunology 154 (3), 236-245, doi:http://dx.doi.org/10.1159/000321110.

Drago, L. et al. Effects of Lactobacillus salivarius LS01 (DSM 22775) treatment on adult atopic dermatitis: A randomized placebo-controlled study. International Journal of Immunopathology and Pharmacology 24 (4), 1037 1048 (2011).

Gore. Treatment and secondary prevention effects of the probiotics Lactobacillus paracasei or Bifidobacterium lactis on early infant eczema: randomized controlled trial with follow-up until age 3 years. Clinical \& Experimental Allergy (2012).

Han, Y., Kim, B., Ban, J., Lee, J., Kim, B. J., Choi, B. S., Hwang, S., Ahn, K., Kim, J., Han, Youngshin, Kim, Bongjoon, Ban, Jeongsook, Lee, Jeongok, Kim, Beom Joon, Choi, Byung Sun, Hwang, Sehee, Ahn, Kangmo, Kim, Jihyun. A randomized trial of Lactobacillus plantarum CJLP133 for the treatment of atopic dermatitis. Pediatric Allergy \& Immunology (2012).

Isolauri, E., Arvola, T., Sutas, Y., Moilanen, E. \& Salminen, S. Probiotics in the management of atopic eczema. Clinical \& Experimental Allergy 30, 1604-1610 (2000).

Taniuchi, S. et al. Administration of Bifidobacterium to infants with atopic dermatitis: changes in fecal microflora and clinical symptoms. Journal of Applied Research 5, 387-396 (2005).

Boyle, R. J., Bath-Hextall, F. J., Leonardi-Bee, J., Murrell, D. F. \& Tang, M. L. Probiotics for the treatment of eczema: a systematic review. Clin Exp Allergy 39, 1117-1127 (2009).

Takwale, A. et al. Efficacy and tolerability of borage oil in adults and children with atopic eczema: randomised, double blind, placebo controlled, parallel group trial. BMJ (Clinical research ed.) 327, 1385 (2003).

Bahmer, F. A. \& Schäfer, J. [Treatment of atopic dermatitis with borage seed oil (Glandol)--a time series analytic study]. Kinderarztliche Praxis 60, 199-202 (1992).

Borrek, S., Hildebrandt, A. \& Forster, J. Gamma-linolenic-acid-rich borage seed oil capsules in children with atopic dermatitis. A placebo-controlled double-blind study. [German]. Klinische Padiatrie 209 (3), 100-104 (1997).

Buslau, M. \& Thaci, D. Atopic dermatitis: Borage oil for systemic therapy. [German]. Zeitschrift fur Dermatologie 182 (3), 131-132+134-136 (1996).

Henz, B. M. et al. Double-blind, multicentre analysis of the efficacy of borage oil in patients with atopic eczema. British Journal of Dermatology 140, 685-688 (1999).

Valsecchi, R., Di Landro, A., Pansera, B. \& Reseghetti, A. Gammalinolenic acid in the treatment of atopic dermatitis [1]. Journal of the European Academy of Dermatology and Venereology 7 (1), 77-79 (1996).

Senapati, S., Banerjee, S. \& Gangopadhyay, D. N. Evening primrose oil is effective in atopic dermatitis: a randomized placebo-controlled trial. Indian Journal of Dermatology, Venereology \& Leprology 74, 447-452 (2008).

Bamford, J. T. et al. Oral evening primrose oil and borage oil for eczema. (2013).

Berth-Jones, J. \& Graham-Brown, R. A. Placebo-controlled trial of essential fatty acid supplementation in atopic dermatitis Lancet 1993 Aug 28;342(8870):564. Lancet (London, England) 341, 1557-1560 (1993).

Biagi, P. L. et al. The effect of gamma-linolenic acid on clinical status, red cell fatty acid composition and membrane microviscosity in infants with atopic dermatitis. Drugs under Experimental and Clinical Research 20 (2), 77-84 (1994).

Bordoni, A. et al. Evening primrose oil (Efamol) in the treatment of children with atopic eczema. Drugs under Experimental and Clinical Research 14 (4), 291-297 (1988).

Hederos, C. A. \& Berg, A. Epogam evening primrose oil treatment in atopic dermatitis and asthma. Archives of Disease in Childhood 75 (6), 494-497 (1996).

Humphreys, F., Symons, J. A., Brown, H. K., Duff, G. W. \& Hunter, J. A. A. The effects of gamolenic acid on adult atopic eczema and premenstrual exacerbation of eczema. European Journal of Dermatology 4 (8), 598-603 (1994).

Mayser, P. et al. A double-blind, randomized, placebo-controlled trial of $n-3$ versus $n-6$ fatty acid-based lipid infusion in atopic dermatitis. Jpen: Journal of Parenteral \& Enteral Nutrition 26, 151-158 (2002).

Bjorneboe, A., Soyland, E., Bjorneboe, G. E., Rajka, G. \& Drevon, C. A. Effect of n-3 fatty acid supplement to patients with atopic dermatitis. Journal of Internal Medicine Supplement 731, 233-236 (1989).

Gimenez-Arnau, A. Effects of linoleic acid supplements on atopic dermatitis. Advances in Experimental Medicine and Biology 433, 285-289 (1997).

Soyland, E. et al. Dietary supplementation with very long-chain $\mathrm{n}-3$ fatty acids in patients with atopic dermatitis. A double-blind, multicentre study. British Journal of Dermatology 130 (6), 757-764 (1994).

Koch, C. et al. Docosahexaenoic acid (DHA) supplementation in atopic eczema: a randomized, double-blind, controlled trial. Br J Dermatol 158, 786-792, doi:10.1111/j.1365-2133.2007.08430.x (2008).

Callaway, J. et al. Efficacy of dietary hempseed oil in patients with atopic dermatitis. Journal of Dermatological Treatment 16, 87-94 (2005). 
Lovell, C. R., Burton, J. L. \& Horrobin, D. F. Treatment of atopic eczema with evening primrose oil. Lancet (London, England) 1, 278 (1981).

Schalin-Karrila, M., Mattila, L., Jansen, C. T. \& Uotila, P. Evening primrose oil in the treatment of atopic eczema: Effect on clinical status, plasma phospholipid fatty acids and circulating blood prostaglandins. British Journal of Dermatology 117 (1), 11-19 (1987).

Wright, S. \& Burton, J. L. Oral evening-primrose-seed oil improves atopic eczema. Lancet (London, England) 2 (8308), 1120-1122 (1982).

Bamford, J. T. et al. Oral evening primrose oil and borage oil for eczema. Cochrane Database Syst Rev 4, CD004416, doi:10.1002/14651858.CD004416.pub2 (2013).

Foelster Holst, R. et al. The novel protease inhibitor SRD441 ointment is not effective in the treatment of adult subjects with atopic dermatitis: results of a randomized, vehicle-controlled study. Allergy 65, 1594-1599, doi:http://dx.doi.org/10.1111/j.1398-9995.2010.02417.x (2010).

Tripodi, S. et al. Lack of efficacy of topical furfuryl palmitate in pediatric atopic dermatitis: A randomized doubleblind study. Journal of Investigational Allergology and Clinical Immunology 19, 204-209 (2009).

Thomas, K. S. et al. A randomised controlled trial of ion-exchange water softeners for the treatment of eczema in children. PLoS medicine 8, e1000395, doi:10.1371/journal.pmed.1000395 (2011).

Griffiths, C. E., Van Leent, E. J., Gilbert, M., Traulsen, J. \& Cipamyflline Study, G. Randomized comparison of the type 4 phosphodiesterase inhibitor cipamfylline cream, cream vehicle and hydrocortisone 17-butyrate cream for the treatment of atopic dermatitis. British Journal of Dermatology 147, 299-307 (2002).

Arkwright, P. D. \& David, T. J. Intradermal administration of a killed Mycobacterium vaccae suspension (SRL 172) is associated with improvement in atopic dermatitis in children with moderate-to-severe disease. The Journal of allergy and clinical immunology 107, 531-534 (2001).

Arkwright, P. D. \& David, T. J. Effect of Mycobacterium vaccae on atopic dermatitis in children of different ages. Br J Dermatol 149, 1029-1034 (2003).

Berth-Jones, J. et al. Killed Mycobacterium vaccae suspension in children with moderate-to-severe atopic dermatitis: a randomized, double-blind, placebo-controlled trial. Clin Exp Allergy 36, 1115-1121, doi:10.1111/j.1365-2222.2006.02558.x (2006).

Brothers, S., Asher, M. I., Jaksic, M. \& Stewart, A. W. Effect of a Mycobacterium vaccae derivative on paediatric atopic dermatitis: A randomized, controlled trial. Clinical and Experimental Dermatology 34, 770-775, doi:http://dx.doi.org/10.1111/j.1365-2230.2008.03153.x (2009).

Kantor, I. et al. Efficacy and safety of emollients as adjunctive agents in topical corticosteroid therapy for atopic dermatitis. Today's Therapeutic Trends 11 (3), 157-166 (1993).

Hanifin, J. M. et al. Effects of a low-potency corticosteroid lotion plus a moisturizing regimen in the treatment of atopic dermatitis. Current Therapeutic Research - Clinical and Experimental 59 (4), 227-233 (1998).

Wilhelm, K. P. \& Scholermann, A. Efficacy and tolerability of a topical preparation containing $10 \%$ urea in patients with atopic dermatitis: <ORIGINAL> WIRKSAMKEIT UND VERTRAGLICHKEIT EINER TOPISCHEN ZUBEREITUNG MIT 10\% UREA (LACERAN (R)) SALBE 10\% UREA) BEI NEURODERMITIS. Aktuelle Dermatologie 24, 26-30 (1998). Larregue, M., Devaux, J., Audebert, C. \& Gelmetti, D. R. A double-blind controlled study on the efficacy and tolerability of $6 \%$ ammonium lactate cream in children with atopic dermatitis. [French]. Nouvelles Dermatologiques 15 (10), 720-721 (1996).

Draelos, Z. D. A clinical evaluation of the comparable efficacy of hyaluronic acid-based foam and ceramidecontaining emulsion cream in the treatment of mild-to-moderate atopic dermatitis. Journal of Cosmetic Dermatology 10 (3), 185-188, doi:http://dx.doi.org/10.1111/j.1473-2165.2011.00568.x (2011).

Draelos, Z. D. \& Draelos, Z. D. An evaluation of prescription device moisturizers. Journal of Cosmetic Dermatology 8, 40-43 (2009).

Wiren, K. et al. Treatment with a barrier-strengthening moisturizing cream delays relapse of atopic dermatitis: A prospective and randomized controlled clinical trial. Journal of the European Academy of Dermatology and Venereology 23, 1267-1272, doi:http://dx.doi.org/10.1111/j.1468-3083.2009.03303.x (2009).

Berardesca, E., Barbareschi, M., Veraldi, S. \& Pimpinelli, N. Evaluation of efficacy of a skin lipid mixture in patients with irritant contact dermatitis, allergic contact dermatitis or atopic dermatitis: a multicenter study. Contact Dermatitis 45, 280-285 (2001).

Sugarman, J. L., Parish, L. C., Sugarman, J. L. \& Parish, L. C. Efficacy of a lipid-based barrier repair formulation in moderate-to-severe pediatric atopic dermatitis. Journal of Drugs in Dermatology: JDD 8, 1106-1111 (2009). Miller. An over the counter moisturizer is as clinically effective as, and more cost-effective than, prescription barrier creams in the treatment of children with mild to moderate atopic dermatitis: A randomised, controlled trial. Journal of Drugs in Dermatology (2011).

Simpson. A New Body Moisturizer Increases Skin Hydration and Improves Atopic Dermatitis Symptoms Among Children and Adults. Journal of Drugs in Dermatology (2011).

Grimalt, R., Mengeaud, V., Cambazard, F. \& Study Investigators', G. The steroid-sparing effect of an emollient therapy in infants with atopic dermatitis: a randomized controlled study. Dermatology 214, 61-67 (2007). Giordano-Labadie, F., Cambazard, F., Guillet, G., Combemale, P. \& Mengeaud, V. Evaluation of a new moisturizer (Exomega milk) in children with atopic dermatitis. Journal of Dermatological Treatment 17, 78-81 (2006). 
Bissonnette, R. et al. A double-blind study of tolerance and efficacy of a new urea-containing moisturizer in patients with atopic dermatitis. Journal of Cosmetic Dermatology, 16-21 (2010). <http://www.mrw.interscience.wiley.com/cochrane/clcentral/articles/896/CN-00751896/frame.html>. Loden, M. et al. A double-blind study comparing the effect of glycerin and urea on dry, eczematous skin in atopic patients. Acta Dermato-Venereologica 82, 45-47 (2002).

Amichai, B. \& Grunwald, M. H. A randomized, double-blind, placebo-controlled study to evaluate the efficacy in $A D$ of liquid soap containing $12 \%$ ammonium lactate $+20 \%$ urea. Clinical \& Experimental Dermatology 34, e602604 (2009).

Msika, P. et al. New Emollient with Topical Corticosteroid-Sparing Effect in Treatment of Childhood Atopic Dermatitis: SCORAD and Quality of Life Improvement. Pediatric Dermatology 25, 606-612 (2008).

De Belilovsky, C. et al. Natural peroxisome proliferator-activated receptor-alpha agonist cream demonstrates similar therapeutic response to topical steroids in atopic dermatitis. Journal of Dermatological Treatment 22 (6), 359-365, doi:http://dx.doi.org/10.3109/09546634.2010.499932 (2011).

Loden, M. et al. Instrumental and dermatologist evaluation of the effect of glycerine and urea on dry skin in atopic dermatitis. Skin Research and Technology 7, 209-213 (2001).

Shibata, R. et al. Clinical effects of kestose, a prebiotic oligosaccharide, on the treatment of atopic dermatitis in infants. Clinical \& Experimental Allergy 39, 1397-1403 (2009).

Ghanei. Effectiveness of prebiotic in atopic dermatitis reduction in 7 to 24 months old children living in Isfahan. Journal of Isfahan Medical School (2011).

van der Aa, L. B. et al. Effect of a new synbiotic mixture on atopic dermatitis in infants: a randomized-controlled trial. Clinical \& Experimental Allergy 40, 795-804 (2010).

Passeron, T., Lacour, J. P., Fontas, E. \& Ortonne, J. P. Prebiotics and synbiotics: two promising approaches for the treatment of atopic dermatitis in children above 2 years. Allergy 61, 431-437 (2006).

Gerasimov, S. V., Vasjuta, V. V., Myhovych, O. O. \& Bondarchuk, L. I. Probiotic supplement reduces atopic dermatitis in preschool children: a randomized, double-blind, placebo-controlled, clinical trial. American Journal of Clinical Dermatology 11, 351-361, doi:http://dx.doi.org/10.2165/11531420-000000000-00000 (2010). Hattori, K. et al. [Effects of administration of bifidobacteria on fecal microflora and clinical symptoms in infants with atopic dermatitis]. [Japanese]. Arerugi - Japanese Journal of Allergology 52, 20-30 (2003).

Murosaki, S. et al. Effects of intake of syrup supplemented with nigerooligosaccharides and heat-killed Lactobacillus plantarum L-137 on skin symptom and immune function in patients with atopic dermatitis. [Japanese]. Japanese Pharmacology and Therapeutics. 34(10)(pp 1087-1096), 2006. Date of Publication: 2006. Farid, R., Ahanchian, H., Jabbari, F. \& Moghiman, T. Effect of a new synbiotic mixture on atopic dermatitis in children: A randomized-controlled trial. Iranian Journal of Pediatrics 21 (2), 225-230 (2011).

Shafiei. Synbiotics could not Reduce the Scoring of Childhood Atopic Dermatitis (SCORAD): A Randomised Double Blind Placebo-Controlled Trial. Iranian Journal of Allergy, Asthma and Immunology (2011).

$\mathrm{Wu}$. Lactobacillus salivarius plus fructo-oligosaccharide is superior to fructo-oligosaccharide alone for treating children with moderate to severe atopic dermatitis: a double-blind, randomized, clinical trial of efficacy and safety. British Journal of Dermatology (2012).

Vita, D. et al. Ass's milk in children with atopic dermatitis and cow's milk allergy: crossover comparison with goat's milk. Pediatric allergy and immunology : official publication of the European Society of Pediatric Allergy and Immunology 18, 594-598 (2007).

Leung, T. F. et al. A randomized, single-blind and crossover study of an amino acid-based milk formula in treating young children with atopic dermatitis. Pediatric allergy and immunology : official publication of the European Society of Pediatric Allergy and Immunology 15, 558-561 (2004).

Jin. Partially hydrolyzed cow's milk formula has a therapeutic effect on the infants with mild to moderate atopic dermatitis: a randomized, double-blind study. Pediatric Allergy \& Immunology (2011).

Koller, D. Y., Halmerbauer, G., Böck, A. \& Engstler, G. Action of a silk fabric treated with AEGIS in children with atopic dermatitis: a 3-month trial. Pediatric allergy and immunology : official publication of the European Society of Pediatric Allergy and Immunology 18, 335-338 (2007).

Stinco, G., Piccirillo, F. \& Valent, F. A randomized double-blind study to investigate the clinical efficacy of adding a non-migrating antimicrobial to a special silk fabric in the treatment of atopic dermatitis. Dermatology 217, 191 195 (2008).

Fontanini C., B. I., Monasta L., Longo G. DermaSilk in long-term control of infantile atopic dermatitis: A double blind randomized controlled trial. Giornale Italiano di Dermatologia e Venereologia, 293 - 297 (2013).

Ozawa, M. et al. Effect of underwear made from MEDIELE on skin barrier function of atopic dermatitis patients in winter season. [Japanese]. Skin Research. 7(4)(pp 475-481), 2008. Date of Publication: August 2008.

Yokoyama, Y., Kimata, H., Mitarai, S., Hirano, S. \& Shirakawa, T. Ethylene vinyl alcohol (EVOH) fiber compared to cotton underwear in the treatment of childhood atopic dermatitis: A double-blind randomized study. Indian Pediatrics 46, 611-614 (2009).

Gauger, A. et al. Efficacy and functionality of silver-coated textiles in patients with atopic eczema. Journal of the European Academy of Dermatology and Venereology : JEADV 20, 534-541, doi:10.1111/j.1468-3083.2006.01526.x (2006). 
Juenger, M. et al. Efficacy and safety of silver textile in the treatment of atopic dermatitis (AD). Current medical research and opinion 22, 739-750 (2006).

Kim, B. \& Kim, C. Effect of mattress and pillow encasings on children with atopic dermatitis. Journal of Allergy \& Clinical Immunology 115, S101-S101 (2005).

Moore, E., Williams, A., Manias, E. \& Varigos, G. Nurse-led clinics reduce severity of childhood atopic eczema: a review of the literature. Br J Dermatol 155, 1242-1248 (2006).

Schuttelaar, M. L., Vermeulen, K. M., Drukker, N. \& Coenraads, P. J. A randomized controlled trial in children with eczema: nurse practitioner vs. dermatologist. Br J Dermatol, 162-170 (2010).

<http://www.mrw.interscience.wiley.com/cochrane/clcentral/articles/334/CN-00742334/frame.html>. Blessmann Weber, M. et al. Improvement of pruritus and quality of life of children with atopic dermatitis and their families after joining support groups. Journal of the European Academy of Dermatology and Venereology. 22(8)(pp 992-997), 2008. Date of Publication: August 2008.

Van Os-Medendorp, H. et al. E-health in caring for patients with atopic dermatitis: A randomized controlled costeffectiveness study of internet-guided monitoring and online self-management training. British Journal of Dermatology 166 (5), 1060-1068, doi:http://dx.doi.org/10.1111/i.1365-2133.2012.10829.x (2012).

Schut C., W. U., Tews N., Gieler U., Deinzer R., Kupfer J. Psychophysiological effects of stress management in patients with atopic dermatitis: A randomized controlled trial. Acta Dermato-Venereologica (2013).

Byremo, G., Rød, G. \& Carlsen, K. H. Effect of climatic change in children with atopic eczema. Allergy 61, 14031410 (2006).

Ricci, G. et al. Effect of house dust mite avoidance measures in children with atopic dermatitis. British Journal of Dermatology 143, 379-384 (2000).

Gutgesell, C. et al. Double-blind placebo-controlled house dust mite control measures in adult patients with dermatitis. British Journal of Dermatology 145, 70-74 (2001).

Oosting, A. J. et al. Effect of mattress encasings on atopic dermatitis outcome measures in a double-blind, placebo-controlled study: the Dutch mite avoidance study. Journal of Allergy \& Clinical Immunology 110, 500-506 (2002).

Sagransky, M. J. et al. A randomized controlled pilot study of the effects of an extra office visit on adherence and outcomes in atopic dermatitis. Archives of Dermatology 146, 1428-1430 (2010).

Glover, M. T. \& Atherton, D. J. A double-blind controlled trial of hyposensitization to Dermatophagoides pteronyssinus in children with atopic eczema. Clinical and Experimental Allergy 22 (4), 440-446 (1992).

Galli, E. et al. Use of a specific oral hyposensitization therapy to Dermatophagoides pteronyssinus in children with atopic dermatitis. Allergologia et immunopathologia 22, 18-22 (1994).

Wen, T. et al. Allergenic potency of SMU-Df extract in comparison with VUS-Df extract; and diagnosis and immunotherapy for atopic dermatitis and rhinitis with SMU-Df extract in China. Arbeiten aus dem Paul-EhrlichInstitut (Bundesamt fur Sera und Impfstoffe) zu Frankfurt a.M (85), 217-227 (1992).

Diepgen, T. L., Salzer, B., Tepe, A. \& Hornstein, O. P. A study of skin irritations by textiles under standardized sweating conditions in patients with atopic eczema. Melliand English 12, 268 (1995).

Diepgen, T. L., Stabler, A. \& Hornstein, O. P. Irritation from textiles in atopic eczema and controls. [German]. $H+G$ Zeitschrift fur Hautkrankheiten 65 (10), 907-910 (1990).

Seymour, J. L., Keswick, B. H., Hanifin, J. M., Jordan, W. P. \& Milligan, M. C. Clinical effects of diaper types on the skin of normal infants and infants with atopic dermatitis. Journal of the American Academy of Dermatology 17 (6), 988-997 (1987).

Oosting, A. J. et al. Effect of mattress encasings on atopic dermatitis outcome measures in a double-blind, placebo-controlled study: the Dutch mite avoidance study. Journal of Allergy and Clinical Immunology 110, 500506 (2002).

Chinn, D. J., Poyner, T. \& Sibley, G. Randomized controlled trial of a single dermatology nurse consultation in primary care on the quality of life of children with atopic eczema. British Journal of Dermatology 146, 432-439 (2002).

Moore, E. J., Williams, A., Manias, E., Varigos, G. \& Donath, S. Eczema workshops reduce severity of childhood atopic eczema. Australasian Journal of Dermatology 50, 100-106, doi:http://dx.doi.org/10.1111/j.14400960.2009.00515.x (2009).

Schuttelaar, M. L. A., Vermeulen, K. M. \& Coenraads, P. J. Costs and cost-effectiveness analysis of treatment in children with eczema by nurse practitioner vs. dermatologist: results of a randomized, controlled trial and a review of international costs. British Journal of Dermatology 165, 600-611, doi:10.1111/j.1365-

2133.2011.10470.x (2011).

Armstrong. Online video improves clinical outcomes in adults with atopic dermatitis: A randomized controlled trial. Journal of the American Academy of Dermatology (2011).

Kim, S. H., Hwang, Sung Hwan, Hong, Soon Kwon, Seo, Jong Keun, Sung, Ho Suk, Park, Sung Wook, Shin, Jeong Hwan. The clinical efficacy, safety and functionality of anion textile in the treatment of atopic dermatitis. Annals of Dermatology (2012).

Adachi, J., Sumitsuzi, H., Endo, K., Fukuzumi, T. \& Aoki, T. Evaluation of the effect of short-term application of deep sea water on atopic dermatitis. [Japanese]. Arerugi = [Allergy] 47 (1), 57-60 (1998). 
Melin, L., Frederiksen, T., Noren, P. \& Swebilius, B. G. Behavioural treatment of scratching in patients with atopic dermatitis. British Journal of Dermatology 115 (4), 467-474 (1986).

Ehlers, A., Stangier, U. \& Gieler, U. Treatment of atopic dermatitis: A comparison of psychological and dermatological approaches to relapse prevention. Journal of Consulting and Clinical Psychology 63 (4), 624-635 (1995).

Salo, O. P., Gordin, A., Brandt, H. \& Antikainen, R. Efficacy and tolerability of erythromycin acistrate and erythromycin stearate in acute skin infections of patients with atopic eczema. Journal of Antimicrobial Chemotherapy 21 (SUPPL. D), 101-106 (1988).

Weinberg, E., Fourie, B., Allmann, B. \& Toerien, A. The use of cefadroxil in superinfected atopic dermatitis. Current Therapeutic Research - Clinical and Experimental 52 (5), 671-676 (1992).

Ewing, C. I. et al. Flucloxacillin in the treatment of atopic dermatitis. British Journal of Dermatology 138 (6), 10221029 (1998).

Larsen, F. S., Simonsen, L., Melgaard, A., Wendicke, K. \& Henriksen, A. S. An efficient new formulation of fusidic acid and betamethasone 17-valerate (fucicort lipid cream) for treatment of clinically infected atopic dermatitis. Acta Dermato-Venereologica 87, 62-68 (2007).

Foelster-Holst, R., Nagel, F., Zoellner, P. \& Spaeth, D. Efficacy of crisis intervention treatment with topical corticosteroid prednicarbat with and without partial wet-wrap dressing in atopic dermatitis. Dermatology (Basel, Switzerland) 212, 66-69 (2006).

Hindley, D., Galloway, G., Murray, J. \& Gardener, L. A randomised study of "wet wraps" versus conventional treatment for atopic eczema. [see comment]. Archives of Disease in Childhood 91, 164-168 (2006).

Pei, A. Y., Chan, H. H. \& Ho, K. M. The effectiveness of wet wrap dressings using $0.1 \%$ mometasone furoate and $0.005 \%$ fluticasone proprionate ointments in the treatment of moderate to severe atopic dermatitis in children. Pediatric Dermatology 18, 343-348 (2001).

Beattie, P. \& al., e. A pilot study on the use of wet wraps in moderate atopic eczema. British Association of Dermatologists 83rd Annual Meeting. Abstract O-8. British Journal of Dermatology 149, 4 (2003).

Schnopp, C. et al. Topical steroids under wet-wrap dressings in atopic dermatitis--a vehicle-controlled trial. Dermatology 204, 56-59 (2002).

Shibagaki, N. et al. [Clinical efficacy of bath additive containing a diamide derivative in patients with atopic dermatitis]. Nishinihon Journal of Dermatology 67, 152-159 (2005).

Harper, J. Double-blind comparison of an antiseptic oil-based bath additive (Oilatum Plus) with regular Oilatum (Oilatum Emollient) for the treatment of atopic eczema. Round Table Series - Royal Society of Medicine, 42-47 (1995).

Holland, K. T., Bojar, R. A. \& Cunliffe, W. J. A comparison of the effect of treatment of atopic eczema with and without antimicrobial compounds. Round Table Series - Royal Society of Medicine (37), 34-41 (1995). Huang, J. T., Abrams, M., Tlougan, B., Rademaker, A. \& Paller, A. S. Treatment of Staphylococcus aureus colonization in atopic dermatitis decreases disease severity. Pediatrics 123, e808-814, doi:10.1542/peds.20082217 (2009).

Lintu, P., Savolainen, J., Kortekangas-Savolainen, O. \& Kalimo, K. Systemic ketoconazole is an effective treatment of atopic dermatitis with IgE-mediated hypersensitivity to yeasts. Allergy 56, 512-517 (2001).

Back \& Bartosik, J. Systemic ketoconazole for yeast allergic patients with atopic dermatitis.[see comment]. Journal of the European Academy of Dermatology \& Venereology 15, 34-38 (2001).

Broberg, A. \& Faergemann, J. Topical antimycotic treatment of atopic dermatitis in the head/neck area. A doubleblind randomised study. Acta Dermato-Venereologica 75 (1), 46-49 (1995).

Wong, A. W., Hon, E. K. \& Zee, B. Is topical antimycotic treatment useful as adjuvant therapy for flexural atopic dermatitis: randomized, double-blind, controlled trial using one side of the elbow or knee as a control. International Journal of Dermatology 47, 187-191 (2008).

Anstey, A. \& Wilkinson, J. D. Lithium succinate ointment in the treatment of atopic eczema[1]. Journal of Dermatological Treatment 2 (1), 37-38 (1991).

Palombo, P. et al. A special pill-mask to re-hydrate the skin affected by atopic dermatitis. Journal of Applied Cosmetology 22, 87-97 (2004).

Stern, T. \& Bayerl, C. Black seed oil ointment - A new approach for the treatment of atopic dermatitis? Aktuelle Dermatologie 28, 74-79 (2002).

Lee, J., Jung, E., Koh, J., Kim, Y. S. \& Park, D. Effect of rosmarinic acid on atopic dermatitis. The Journal of dermatology 35, 768-771 (2008).

Thumm, E. J., Stoss, M., Bayerl, C. \& Schurholz, T. h. Randomized trial to study efficacy of a $20 \%$ and $10 \%$ Hippophae rhamnoides containing creme used by patients with mild to intermediate atopic dermatitis. Aktuelle Dermatologie 26, 285-290 (2000).

Korting, H. C., Schollmann, C., Cholcha, W., Wolff, L. \& Collaborative Study, G. Efficacy and tolerability of pale sulfonated shale oil cream $4 \%$ in the treatment of mild to moderate atopic eczema in children: a multicentre, randomized vehicle-controlled trial. Journal of the European Academy of Dermatology \& Venereology 24, 1176 1182, doi:http://dx.doi.org/10.1111/j.1468-3083.2010.03616.x (2010).

Guéniche, A. et al. Improvement of atopic dermatitis skin symptoms by Vitreoscilla filiformis bacterial extract. European journal of dermatology : EJD 16, 380-384 (2006). 
257 Gueniche, A. et al. Effects of nonpathogenic gram-negative bacterium Vitreoscilla filiformis lysate on atopic dermatitis: a prospective, randomized, double-blind, placebo-controlled clinical study. British Journal of Dermatology 159, 1357-1363 (2008).

Dolle, S. et al. Long-term reduction in local inflammation by a lipid raft molecule in atopic dermatitis. Allergy: European Journal of Allergy and Clinical Immunology 65 (9), 1158-1165, doi:http://dx.doi.org/10.1111/i.13989995.2010.02341.x (2010).

259 Bigliardi, P. L. et al. Treatment of pruritus with topically applied opiate receptor antagonist. Journal of the American Academy of Dermatology 56, 979-988 (2007).

260 Stucker, M. et al. Topical vitamin B12--a new therapeutic approach in atopic dermatitis-evaluation of efficacy and tolerability in a randomized placebo-controlled multicentre clinical trial. British Journal of Dermatology 150, 977983 (2004).

261 Januchowski, R. Evaluation of topical vitamin B12 for the treatment of childhood eczema. J Altern Complement Med 15, 387-389. (2009).

262 Bissonnette. Efficacy and safety of topical WBI-1001 in patients with mild to severe atopic dermatitis: results from a 12-week, multicentre, randomized, placebo-controlled double-blind trial. British Journal of Dermatology (2012).

263 Bissonnette, R. et al. Efficacy and safety of topical WBI-1001 in the treatment of atopic dermatitis: results from a phase 2A, randomized, placebo-controlled clinical trial. Archives of Dermatology 146, 446-449 (2010).

264 Gandy, J. J. et al. Randomized, parallel-group, double-blind, controlled study to evaluate the efficacy and safety of carbohydrate-derived fulvic acid in topical treatment of eczema. Clinical, Cosmetic and Investigational Dermatology CCID 4, 145-148 (2011).

265 Misery, L., Liege, P. \& Cambazard, F. [Evaluation of efficacy and tolerance of a cream containing raffinose during atopic dermatitis]. Nouvelles Dermatologiques 24, 339-341 (2005).

266 Katsuyama, M. et al. A novel method to control the balance of skin microflora Part 2. A study to assess the effect of a cream containing farnesol and xylitol on atopic dry skin. Journal of dermatological science 38, 207-213 (2005).

267 Arenberger, P., Arenbergerova, M., Drozenova, H., Hladikova, M. \& Holcova, S. Effect of topical heparin and levomenol on atopic dermatitis: a randomized four-arm, placebo-controlled, double-blind clinical study. Journal of the European Academy of Dermatology and Venereology : JEADV 25, 688-694, doi:10.1111/j.14683083.2010.03950.x (2011).

268 Mora, R. et al. Efficacy of a topical suspension of bacterial antigens for the management of recurrent eczema in children. Medical science monitor : international medical journal of experimental and clinical research 10, PI99PI103 (2004).

269 Patzelt-Wenczler, R. \& Ponce-Poschl, E. Proof of efficacy of Kamillosan(R) cream in atopic eczema. European Journal of Medical Research 5, 171-175 (2000).

270 Hamada, M. et al. The usefulness of camellia oil spray for treatment of atopic dermatitis. [Japanese]. Nishinihon Journal of Dermatology. 70(2)(pp 213-218), 2008. Date of Publication: 2008.

271 Wu S.-H., C. X.-Q., Liu B., Wu H.-J., Dong L. Efficacy and safety of 15(R/S)-methyl-lipoxin A4 in topical treatment of infantile eczema. British Journal of Dermatology (2013).

272 Hashizume, E., Nakano, Tetsuo, Kamimura, Ayako, Morishita, Koji. Topical effects of N-acetyl-L-hydroxyproline on ceramide synthesis and alleviation of pruritus. Clinical, cosmetic and investigational dermatology (2013).

273 Herzog, J. L. et al. A randomized, double-blind, vehicle-controlled crossover study to determine the anti-pruritic efficacy, safety and local dermal tolerability of a topical formulation (SRD174 cream) of the long-acting opiod antagonist nalmefene in subjects with atopic dermatitis. Journal of Drugs in Dermatology 10 (8), $853-860$ (2011).

274 Udompataikul. Comparative trial of moisturizer containing licochalcone A vs. hydrocortisone lotion in the treatment of childhood atopic dermatitis: a pilot study. Journal of the European Academy of Dermatology \& Venereology (2011).

275 Patrizi, A., Raone, B, Raboni, R, Neri, I. Efficacy and tolerability of a cream containing AR-GG27 (sorbityl furfural palmitate) in the treatment of mild/moderate childhood atopic dermatitis associated with pityriasis alba. A double-blind, placebo-controlled clinical trial. Giornale italiano di dermatologia e venereologia : organo ufficiale, Societa italiana di dermatologia e sifilografia (2012).

276 Veien, N. K., Kaaber, K., Larsen, P. O., Nielsen, A. O. \& Thestrup-Pedersen, K. Ranitidine treatment of hand eczema in patients with atopic dermatitis: A double-blind, placebo-controlled trial. Journal of the American Academy of Dermatology 32 (6), 1056-1057 (1995).

277 Schram. A randomized trial of methotrexate versus azathioprine for severe atopic eczema. Journal of Allergy and Clinical Immunology (2011).

278 Haeck. Enteric-coated mycophenolate sodium versus cyclosporin A as long-term treatment in adult patients with severe atopic dermatitis: A randomized controlled trial. Journal of the American Academy of Dermatology (2011). El-Khalawany, M. A., Hassan, Hatem, Shaaban, Dalia, Ghonaim, Noha, Eassa, Bayoumi. Methotrexate versus cyclosporine in the treatment of severe atopic dermatitis in children: a multicenter experience from Egypt. European journal of pediatrics, 351 - 356 (2013). 
Pei, A. Y., Chan, H. H. \& Leung, T. F. Montelukast in the treatment of children with moderate-to-severe atopic dermatitis: a pilot study. Pediatric allergy and immunology : official publication of the European Society of Pediatric Allergy and Immunology 12, 154-158 (2001).

Yanase, D. J. \& David-Bajar, K. The leukotriene antagonist montelukast as a therapeutic agent for atopic dermatitis. Journal of the American Academy of Dermatology 44, 89-93 (2001).

Friedmann, P. S. et al. A double-blind, placebo-controlled trial of montelukast in adult atopic eczema. Clin Exp Allergy 37, 1536-1540, doi:10.1111/j.1365-2222.2007.02811.x (2007).

Veien, N. K., Busch-Sorensen, M. \& Stausbol-Gron, B. Montelukast treatment of moderate to severe atopic dermatitis in adults: a randomized, double-blind, placebo-controlled trial. Journal of the American Academy of Dermatology 53, 147-149 (2005).

Rahman, M. L., Choudhury, A. M. \& Islam, M. M. Effectiveness of montelukast in the treatment of atopic dermatitis. Mymensingh Medical Journal: MMJ 15, 85-88 (2006).

Capella, G. L., Grigerio, E. \& Altomare, G. A randomized trial of leukotriene receptor antagonist montelukast in moderate-to-severe atopic dermatitis of adults. European journal of dermatology : EJD 11, 209-213 (2001).

Pajno, G. B. et al. Sublingual immunotherapy in mite-sensitized children with atopic dermatitis: a randomized, double-blind, placebo-controlled study. Journal of Allergy \& Clinical Immunology 120, 164-170 (2007).

Silny, W. \& Czarnecka-Operacz, M. [Specific immunotherapy in the treatment of patients with atopic dermatitis-results of double blind placebo controlled study]. Polski merkuriusz lekarski : organ Polskiego Towarzystwa Lekarskiego 21, 558-565 (2006).

Oldhoff, J. M. et al. Anti-IL-5 recombinant humanized monoclonal antibody (mepolizumab) for the treatment of atopic dermatitis. Allergy 60, 693-696 (2005).

Heil, P. M., Maurer, D., Klein, B., Hultsch, T. \& Stingl, G. Omalizumab therapy in atopic dermatitis: depletion of IgE does not improve the clinical course - a randomized, placebo-controlled and double blind pilot study. Journal der Deutschen Dermatologischen Gesellschaft 8, 990-998, doi:http://dx.doi.org/10.1111/i.1610-0387.2010.07497.x (2010).

Paul, C., Lahfa, M., Bachelez, H., Chevret, S. \& Dubertret, L. A randomized controlled evaluator-blinded trial of intravenous immunoglobulin in adults with severe atopic dermatitis [see comments]. British Journal of Dermatology 147, 518-522 (2002).

Jee. Long-Term Efficacy of Intravenous Immunoglobulin Therapy for Moderate to Severe Childhood Atopic Dermatitis. Asthma, Allergy and Immunology Research (2011).

Wolff, K. et al. Efficacy and tolerability of three different doses of oral pimecrolimus in the treatment of moderate to severe atopic dermatitis: a randomized controlled trial. British Journal of Dermatology 152, 12961303 (2005).

White, C. R. \& Hanifin, J. M. Levamisole therapy in atopic dermatitis. Randomized double-blind evaluation. Archives of Dermatology 114 (9), 1314-1315 (1978).

Hanifin, J. M. et al. Recombinant interferon gamma therapy for atopic dermatitis. Journal of the American Academy of Dermatology 28 (2 I), 189-197 (1993).

Abeck, D. et al. Topical application of a platelet-activating factor (PAF) antagonist in atopic dermatitis. Acta Dermato-Venereologica 77 (6), 449-451 (1997).

Schmitt, J. et al. Prednisolone vs. ciclosporin for severe adult eczema. An investigator-initiated double-blind placebo-controlled multicentre trial. British Journal of Dermatology 162, 661-668 (2010).

Jang, I. G. et al. Clinical improvement and immunohistochemical findings in severe atopic dermatitis treated with interferon gamma. Journal of the American Academy of Dermatology 42, 1033-1040 (2000).

Bemanian, M. H. et al. High doses intravenous immunoglobulin versus oral cyclosporine in the treatment of severe atopic dermatitis. Iranian Journal of Allergy Asthma \& Immunology 4, 139-143 (2005).

Diepgen, T. L. \& Early Treatment of the Atopic Child Study, G. Long-term treatment with cetirizine of infants with atopic dermatitis: a multi-country, double-blind, randomized, placebo-controlled trial (the ETAC trial) over 18 months. Pediatric allergy and immunology : official publication of the European Society of Pediatric Allergy and Immunology 13, 278-286 (2002).

Munday, J. et al. Chlorpheniramine is no more effective than placebo in relieving the symptoms of childhood atopic dermatitis with a nocturnal itching and scratching component. Dermatology 205, 40-45 (2002).

Kawashima, M. et al. Addition of fexofenadine to a topical corticosteroid reduces the pruritus associated with atopic dermatitis in a 1-week randomized, multicentre, double-blind, placebo-controlled, parallel-group study. British Journal of Dermatology 148, 1212-1221 (2003).

Nakagawa, H. \& Kawashima, M. [Efficacy and safety of fexofenadine hydrochloride in pediatric patients with atopic dermatitis in a phase III, randomized, double-blind, multi-center comparative study]. Nishinihon Journal of Dermatology 68, 553-565 (2006).

Kawashima. Olopatadine hydrochloride in children: Evidenced efficacy and safety for atopic dermatitis treatment in a randomized, multicenter, double-blind, parallel group comparative study. Nishinihon Journal of Dermatology (2011).

Berth-Jones, J. \& Graham-Brown, R. A. Failure of terfenadine in relieving the pruritus of atopic dermatitis. British Journal of Dermatology 121, 635-637 (1989). 
Doherty, V. et al. Treatment of itching in atopic eczema with antihistamines with a low sedative profile. BMJ (Clinical research ed.) 298, 96 (1989).

Foulds, I. S. \& MacKie, R. M. A double-blind trial of the $\mathrm{H} 2$ receptor antagonist cimetidine, and the $\mathrm{H} 1$ receptor antagonist promethazine hydrochloride in the treatment of atopic dermatitis. Clinical Allergy 11, 319-323 (1981). Frosch, P. J., Schwanitz, H. J. \& Macher, E. A double blind trial of $\mathrm{H} 1$ and $\mathrm{H} 2$ receptor antagonists in the treatment of atopic dermatitis. Archives of Dermatological Research 276, 36-40 (1984).

Hamada, T. et al. Evaluation of the clinical effect of terfenadine in patients with atopic dermatitis. A comparison of strong corticosteroid therapy to mild topical corticosteroid combined with terfenadine administration therapy. [Japanese]. Skin Research 38 (1), 97-103 (1996).

Hannuksela, M. et al. Dose ranging study: Cetirizine in the treatment of atopic dermatitis in adults. Annals of Allergy 70 (2), 127-133 (1993).

Henz, B. M., Metzenauer, P., O'Keefe, E. \& Zuberbier, T. Differential effects of new-generation H1-receptor antagonists in pruritic dermatoses. Allergy: European Journal of Allergy and Clinical Immunology 53 (2), 180-183 (1998).

Hjorth, N. Terfenadine in the treatment of chronic idiopathic urticaria and atopic dermatitis. Cutis 42 (4 A), 29-30 (1988).

Ishibashi, Y. et al. Clinical evaluation of E-0659 in atopic dermatitis in infants and children. Dose-finding multicenter study by the double-blind method. [Japanese]. Skin Research 31 (3), 458-471 (1989).

Ishibashi, Y. et al. Clinical evaluation of E-0659 on atopic dermatitis. Multicenter double-blind study in comparison with ketotifen. Rinsho Hyoka 17, 77-115 (1989).

Klein, G. L. \& Galant, S. P. A comparison of the antipruritic efficacy of hydroxyzine and cyproheptadine in children with atopic dermatitis. Annals of Allergy 44 (3), 142-145 (1980).

Langeland, T., Fagertun, H. E. \& Larsen, S. Therapeutic effect of loratadine on pruritus in patients with atopic dermatitis. A multi-crossover-designed study. Allergy: European Journal of Allergy and Clinical Immunology 49 (1), 22-26 (1994).

La Rosa, M. et al. Double-blind study of cetirizine in atopic eczema in children. Annals of Allergy 73 (2), 117-122 (1994).

Monroe, E. W. Relative efficacy and safety of loratadine, hydroxyzine, and placebo in chronic idiopathic urticaria and atopic dermatitis. Clinical Therapeutics 14 (1), 17-21 (1992).

Patel, P. et al. A double-blind study of loratadine and cetirizine in atopic dermatitis. Journal of Dermatological Treatment 8 (4), 249-253 (1997).

Savin, J. A., Paterson, W. D., Adam, K. \& Oswald, I. Effects of trimeprazine and trimipramine on nocturnal scratching in patients with atopic eczema. Archives of Dermatology 115 (3), 313-315 (1979).

Savin, J. A., Dow, R. \& Harlow, B. J. The effect of a new non-sedative H1-receptor antagonist (LN2974) on the itching and scratching of patients with atopic eczema. Clinical and Experimental Dermatology 11 (6), 600-602 (1986).

Simons, F. E., Simons, K. J., Becker, A. B. \& Haydey, R. P. Pharmacokinetics and antipruritic effects of hydroxyzine in children with atopic dermatitis. Journal of Pediatrics 104, 123-127 (1984).

Simons, F. E. R. Prospective, long-term safety evaluation of the H1-receptor antagonist cetirizine in very young children with atopic dermatitis. Journal of Allergy and Clinical Immunology 104 (2 I), 433-440 (1999).

Wahlgren, C. F., Hagermark, O. \& Bergstrom, R. The antipruritic effect of a sedative and a non-sedative antihistamine in atopic dermatitis. British Journal of Dermatology 122 (4), 545-551 (1990).

Zuluaga de Cadena, A. et al. [Comparative study of the effect of the hidroxicina the terfenadina and the astemizol in children with atopic demratitis: Hospital General de Medellin-Centro de Especialistas CE.S. 1986-1988]. CES med 3, 7-13 (1989).

Lee, H. J., Park, C. O., Lee, J. H. \& Lee, K. H. [The antipruritic effect of topical doxepin cream in patients with atopic dermatitis]. Korean Journal of Dermatology 44, 309-314 (2006).

Stainer, R. et al. Efficacy and acceptability of a new topical skin lotion of sodium cromoglicate (Altoderm) in atopic dermatitis in children aged 2-12 years: a double-blind, randomized, placebo-controlled trial. British Journal of Dermatology 152, 334-341 (2005).

Malekzad, F. et al. Efficacy of oral naltrexone on pruritus in atopic eczema: A double-blind, placebo-controlled study. Journal of the European Academy of Dermatology and Venereology 23, 948-950, doi:http://dx.doi.org/10.1111/j.1468-3083.2009.03129.x (2009).

Kief, $\mathrm{H}$. [A prospective, controlled study on the efficacy of the treatment with AHIT and treatment with Patient's blood in atopic dermatitis]. Aktuelle Dermatologie 33, 216-227 (2007).

Pittler, M. H. et al. Randomized, double-blind, placebo-controlled trial of autologous blood therapy for atopic dermatitis. British Journal of Dermatology 148, 307-313 (2003).

Byun. Full-spectrum light phototherapy for atopic dermatitis. International Journal of Dermatology (2011). Brenninkmeijer, E. E. A. et al. Excimer laser vs. clobetasol propionate $005 \%$ ointment in prurigo form of atopic dermatitis: A randomized controlled trial, a pilot. British Journal of Dermatology 163 (4), 823-831, doi:http://dx.doi.org/10.1111/j.1365-2133.2010.09858.x (2010). 
Ebata, T., Izumi, H., Aizawa, H., Kamide, R. \& Niimura, M. Effects of nitrazepam on nocturnal scratching in adults with atopic dermatitis: A double-blind placebo-controlled crossover study. British Journal of Dermatology 138 (4), 631-634 (1998).

Ruzicka, T. Effect of theophylline in atopic dermatitis: A double-blind cross-over study. Archives of Dermatological Research 269 (1), 109-110 (1980).

Archer, C. B. \& Macdonald, D. M. Treatment of atopic dermatitis with salbutamol. Clinical and Experimental Dermatology 12 (5), 323-325 (1987).

Berth-Jones, J. \& Graham-Brown, R. A. Failure of papaverine to reduce pruritus in atopic dermatitis: a doubleblind, placebo-controlled cross-over study. British Journal of Dermatology 122, 553-557 (1990).

Yoshihara, S. et al. Usefulness of suplatast tosilate, a Th2 cytokine inhibitor based on the Th1/Th2 ratio for allergic disease in children: a retrospective study. Arzneimittel-Forschung, 421-424 (2011).

Kawana, S., Kato, Y. \& Omi, T. Efficacy of a 5-HT1a receptor agonist in atopic dermatitis. Clinical \& Experimental Dermatology 35, 835-840, doi:http://dx.doi.org/10.1111/j.1365-2230.2009.03771.x (2010).

Ramirez-Bosca, A., Zapater, P., Betlloch, I., Albero, F., Martinez, A., Diaz-Alperi, J., Horga, J. F. Polypodium leucotomos extract in atopic dermatitis: A randomized, double-blind, placebo-controlled, multicenter trial. [Spanish]. Actas Dermo-Sifiliograficas (2012).

Pfab. Effect of Acupuncture on Allergen-Induced Basophil Activation in Patients with Atopic Eczema: A Pilot Trial. The Journal of Alternative and Complementary Medicine (2011).

Lee. Effectiveness of acupressure on pruritus and lichenification associated with atopic dermatitis: a pilot trial. Acupuncture in Medicine (2012).

Senser, C., Habermuller, M. \& Revenstorf, D. [Hypnotherapy in atopic dermatitis]. Aktuelle Dermatologie 30, 103108 (2004).

Anderson, C., Lis-Balchin, M. \& Kirk-Smith, M. Evaluation of massage with essential oils on childhood atopic eczema. Phytotherapy Research 14, 452-456 (2000).

Shi, Y. J., Zhang, C. M. \& Ma, D. M. [Clinical study on treatment of atopic dermatitis by integrated traditional Chinese and Western medicine]. [Chinese]. Zhongguo Zhong Xi Yi Jie He Za Zhi Zhongguo Zhongxiyi Jiehe Zazhi/Chinese Journal of Integrated Traditional \& Western Medicine/Zhongguo Zhong Xi Yi Jie He Xue Hui, Zhongguo Zhong Yi Yan Jiu Yuan Zhu Ban 28, 686-688 (2008).

Henderson, C. A., Morris, A., Wilson, A. \& Ilchyshyn, A. An open study comparing the efficacy of two different Chinese herbal therapy formulations in atopic eczema and their effects on circulating activated T-lymphocytes. Journal of Dermatological Treatment 11, 91-96 (2000).

Hon, K. L., Chan, B. C. \& Leung, P. C. Chinese herbal medicine research in eczema treatment. Chin Med 6, 17 (2011).

Cheng. The Efficacy and Safety of a Chinese Herbal Product (Xiao-Feng-San) for the Treatment of Refractory Atopic Dermatitis: A Randomized, Double-Blind, Placebo-Controlled Trial. International Archives of Allergy \& Immunology (2011).

Shapira, M. Y. et al. Treatment of atopic dermatitis with herbal combination of Eleutherococcus, Achillea millefolium, and Lamium album has no advantage over placebo: a double blind, placebo-controlled, randomized trial. Journal of the American Academy of Dermatology 52, 691-693 (2005).

Choi, I. H., Kim, S., Kim, Y., Yun, Y., Choi, In-Hwa, Kim, Sehyun, Kim, YoungChul, Yun, Younghee. The effect of TJ-15 plus TJ-17 on atopic dermatitis: a pilot study based on the principle of pattern identification. Journal of Alternative \& Complementary Medicine (2012).

Schempp, C. M., Hezel, S. \& Simon, J. C. Topical treatment of atopic dermatitis with Hypericum cream. A randomised, placebo-controlled, double-blind half-side comparison study. (German). Hautarzt 54, 248-253 (2003).

Sheehan, M. P. et al. Efficacy of traditional Chinese herbal therapy in adult atopic dermatitis. Lancet (London, England) 340 (8810), 13-17 (1992).

Sheehan, M. P. \& Atherton, D. J. A controlled trial of traditional Chinese medicinal plants in widespread nonexudative atopic eczema. British Journal of Dermatology 126 (2), 179-184 (1992).

Fung, A. Y. P., Look, P. C. N., Chong, L. Y., But, P. P. H. \& Wong, E. A controlled trial of traditional Chinese herbal medicine in Chinese patients with recalcitrant atopic dermatitis. International Journal of Dermatology 38 (5), 387392 (1999).

Latchman, Y., Banerjee, P., Poulter, L. W., Rustin, M. \& Brostoff, J. Association of immunological changes with clinical efficacy in atopic eczema patients treated with traditional Chinese herbal therapy (Zemaphyte). International Archives of Allergy and Immunology 109 (3), 243-249 (1996).

Schachner, L., Field, T., Hernandez-Reif, M., Duarte, A. M. \& Krasnegor, J. Atopic dermatitis symptoms decreased in children following massage therapy. Pediatric Dermatology 15, 390-395 (1998). 
Table 1: Treatments with reasonable evidence of benefit for eczema patients

\begin{tabular}{|c|c|c|c|c|c|}
\hline Intervention and severity of AE & Population & Trials (n) & Participants (n) & Risk of bias & Systematic Review(s) \\
\hline \multicolumn{6}{|l|}{ Topical Corticosteroids } \\
\hline Corticosteroids (various strengths) are superior to vehicle for AE of all severities & $\begin{array}{l}\text { Adults and } \\
\text { children }\end{array}$ & $23^{1-22}$ & 3857 & $\begin{array}{l}\text { Mostly } \\
\text { unclear }\end{array}$ & None \\
\hline \multicolumn{6}{|l|}{ Topical Calcineurin Inhibitors } \\
\hline Pimecrolimus (1\%) is superior to vehicle for mild to moderate AE & $\begin{array}{l}\text { Mainly } \\
\text { children }\end{array}$ & $16^{23-37}$ & 3149 & $\begin{array}{l}\text { Mostly } \\
\text { unclear }\end{array}$ & $\begin{array}{l}\text { Chen }(2011)^{38} \\
\text { Number of included studies: } 6 \\
\text { Meta-analysis: OR } 3.21,95 \% \mathrm{Cl} 2.48 \text { to } 4.14\end{array}$ \\
\hline Tacrolimus $(0.03,0.1,0.3 \%)$ is superior to vehicle for moderate to severe $\mathrm{AE}$ & $\begin{array}{l}\text { Adults and } \\
\text { children }\end{array}$ & $9^{39-45}$ & 2089 & $\begin{array}{l}\text { Mostly } \\
\text { unclear }\end{array}$ & $\begin{array}{l}\text { Chen }(2011)^{38} \\
\text { Number of included studies: } 4 \\
\text { Meta-analysis: OR } 4.56,95 \% \mathrm{Cl} 2.80 \text { to } 7.44\end{array}$ \\
\hline Tacrolimus $(0.1 \%)$ superior to fluticasone propionate ointment $(0.005 \%)$ for moderate to severe facial AE & Adults & $1^{49}$ & 568 & $\begin{array}{l}\text { Mostly } \\
\text { unclear }\end{array}$ & Not applicable \\
\hline Tacrolimus $(0.1,0.03 \%)$ is superior to pimecrolimus $(1 \%)$ for $\mathrm{AE}$ of all severities & $\begin{array}{l}\text { Adults and } \\
\text { children }\end{array}$ & $5^{50-52}$ & 1243 & Mostly low & $\begin{array}{l}\text { Martins }(2015)^{53} \\
\text { Number of included studies: } 3 \\
\text { Meta-analysis: RR } 1.80,95 \% \mathrm{Cl} 1.35 \text { to } 2.42\end{array}$ \\
\hline \multicolumn{6}{|l|}{ Proactive (maintenance) topical therapy for preventing flares } \\
\hline Corticosteroids applied twice a week are superior to vehicle for moderate to severe AE & $\begin{array}{l}\text { Adults and } \\
\text { children }\end{array}$ & $4^{54-57}$ & 929 & $\begin{array}{l}\text { Mostly } \\
\text { unclear }\end{array}$ & $\begin{array}{l}\text { Schmitt }(2011)^{58} \\
\text { Number of included studies: } 4 \\
\text { Meta-analysis: RR 0.46, } 95 \% \text { Cl } 0.38-0.55\end{array}$ \\
\hline Tacrolimus $(0.1,0.03 \%)$ applied twice a week is superior to vehicle for mild to severe AE & $\begin{array}{l}\text { Adults and } \\
\text { children }\end{array}$ & $4^{59-62}$ & 741 & $\begin{array}{l}\text { Mostly } \\
\text { unclear }\end{array}$ & $\begin{array}{l}\text { Schmitt }(2011)^{58} \\
\text { Number of included studies: } 3 \\
\text { Meta-analysis: RR 0.78, } 95 \% \text { Cl 0.60-1.00 }\end{array}$ \\
\hline Pimecrolimus (1\%) applied twice a week is superior to vehicle for AE of all severities & $\begin{array}{l}\text { Mainly } \\
\text { children }\end{array}$ & $2^{24,63}$ & 251 & Mostly low & None \\
\hline \multicolumn{6}{|l|}{ Systemic Therapies } \\
\hline Ciclosporin superior to placebo for severe $\mathrm{AE}$ & Adults & $4^{64-67}$ & 113 & $\begin{array}{l}\text { Mostly } \\
\text { unclear }\end{array}$ & $\begin{array}{l}\text { Schmitt } 2007^{68} \\
\text { Number of included studies: (12) } \\
\text { Meta-analysis: (included non-RCTs) }\end{array}$ \\
\hline Azathioprine superior to placebo for moderate to severe $A E$ & Adults & $2^{69,70}$ & 100 & Mostly low & $\begin{array}{l}\text { Schram } 2011^{71} \\
\text { Number of included studies: } \\
\text { Meta-analysis: }\end{array}$ \\
\hline \multicolumn{6}{|l|}{ Ultra-violet Light Therapy } \\
\hline NB-UVB superior to placebo (visible light) for moderate to severe $A E$ & Adults & $2^{72,73}$ & 116 & $\begin{array}{l}\text { Mostly } \\
\text { unclear }\end{array}$ & $\begin{array}{l}\text { Gambichler } 2005^{74} \\
\text { Number of included studies: } \\
\text { Meta-analysis: } \\
\text { Dogra } 2015\end{array}$ \\
\hline \multicolumn{6}{|l|}{ Other } \\
\hline Atopiclair ${ }^{\mathrm{TM}}$ superior to vehicle for mild to moderate $\mathrm{AE}$ & $\begin{array}{l}\text { Adults and } \\
\text { children }\end{array}$ & $4^{75-79}$ & 489 & Mixed & None \\
\hline
\end{tabular}




\begin{tabular}{|c|c|c|c|c|c|c|}
\hline Intervention & $\begin{array}{l}\text { No. of } \\
\text { Trials }\end{array}$ & $\begin{array}{l}\text { No. of } \\
\text { Participants }\end{array}$ & Risk of bias & $\begin{array}{l}\text { Population } \\
\text { applied to }\end{array}$ & Severity of AE & Relevant systematic reviews \\
\hline Twice daily versus once daily topical corticosteroids & $3^{14,89,90}$ & 617 & $\begin{array}{l}\text { Mainly unclear risk of } \\
\text { bias }\end{array}$ & $\begin{array}{l}\text { Adults and } \\
\text { children }\end{array}$ & $\begin{array}{l}\text { Mainly } \\
\text { unspecified }\end{array}$ & $\begin{array}{l}\text { Green }(2005)^{91} \\
\text { Number of included studies: } 10 \\
\text { Meta-analysis: not preformed (heterogeneity) }\end{array}$ \\
\hline $\begin{array}{l}\text { Topical corticosteroids in combination with antibiotics for AE that is not } \\
\text { clinically infected versus topical corticosteroid only }\end{array}$ & $5^{92-96}$ & 352 & $\begin{array}{l}\text { Mainly low or unclear } \\
\text { risk of bias }\end{array}$ & Mainly unspecified & Mild to severe & $\begin{array}{l}\text { Bath-Hextall (2010) }{ }^{97} \\
\text { Number of included studies: } 2 \\
\text { Meta-analysis: RR } 0.52,95 \% \mathrm{Cl} 0.23 \text { to } 1.16\end{array}$ \\
\hline Probiotics for treating established AE versus placebo & $20^{98-117}$ & 1513 & $\begin{array}{l}\text { Mainly unclear risk of } \\
\text { bias }\end{array}$ & Mainly children & Unspecified & $\begin{array}{l}\text { Boyle }(2009)^{118} \\
\text { Number of included studies: } 5 \\
\text { Meta-analysis: mean difference }-0.90,95 \% \mathrm{Cl}-2.84 \text { to } \\
1.04\end{array}$ \\
\hline $\begin{array}{l}\text { Dietary supplements rich in linoleic acid such as evening primrose oil and } \\
\text { borage oil versus placebo }\end{array}$ & $23^{119-140}$ & 1448 & $\begin{array}{l}\text { Mainly unclear risk of } \\
\text { bias }\end{array}$ & Mainly adults & Unspecified & $\begin{array}{l}\text { Bamford (2013) }{ }^{141} \\
\text { Number of included studies: evening primrose oil ( } 7 \\
\text { trials) } \\
\text { Meta-analysis for Evening Primrose Oil mean } \\
\text { difference }-2.22,95 \% \mathrm{Cl}-10.48 \text { to } 6.04 . \\
\text { Number of included studies: borage oil ( } 8 \text { trials) } \\
\text { Meta-analysis for borage oil: not preformed } \\
\text { (heterogeneity) }\end{array}$ \\
\hline $\begin{array}{l}\text { Other topical treatment: protease inhibitor SRD441 versus vehicle in } \\
\text { adults with mild to moderate } \mathrm{AE}\end{array}$ & $1^{142}$ & 93 & Mainly low risk of bias & Adults & Mild to moderate & SR not applicable \\
\hline $\begin{array}{l}\text { Other topical treatment: emollient with furfuryl palmitate versus } \\
\text { emollient only }\end{array}$ & $1^{143}$ & 117 & Low risk of bias & Children & Unspecified & SR not applicable \\
\hline Ion exchange water softening devices versus no water softening & $1^{144}$ & 336 & Low risk of bias & Children & $\begin{array}{l}\text { Moderate to } \\
\text { severe }\end{array}$ & SR not applicable \\
\hline Other topical treatment: cipamfylline cream versus vehicle & $1^{145}$ & 103 & Mainly low risk of bias & Adults & Unspecified & SR not applicable \\
\hline Mycobacterium vaccae vaccine versus no vaccine & $4^{146-149}$ & 372 & Low risk of bias & Mainly children & $\begin{array}{l}\text { Moderate to } \\
\text { severe }\end{array}$ & None \\
\hline
\end{tabular}




\section{Intervention}

\section{Emollients}

Dietary interventions including prebiotics, dietary restrictions, and synbiotics

Non-pharmacological interventions, including: specialised clothing (silk or synthetic fibres with or without antibiotics); environmental interventions (house dust mite reduction, desensitisation); staying

in a different climate; different approaches to organisation of care such as additional visits to the doctors or nurse led clinics; support groups; e-health management; psychological therapies (stress

reduction or habit reversal techniques); balneotherapy (salt baths); biofeedback

Oral antibiotics for clinically infected or uninfected AE

Topical corticosteroids combined with topical antibiotics for infected $A E$

Wet wraps in addition to topical corticosteroids

Antiseptic bath additives

Systemic and topical antifungals

Topical treatments including: topical vitamin B12; topical coal tar; camellia oil; SRD441 (protease inhibitor); WBI-1001 (an inhibitor of T cell inflammatory cytokine secretion); hippophe rhamnoides;

black seed oil; pill mask; rosmarinic acid; vitreoscilla filiformis; shale oil; miltefosine; opiate receptor antagonist; carbohydrate derived fulvic acid; raffinose; farnesol and xylitol, bacterial antigens;

camomile extract; heparin and levomenol; 15(R/S)-Methyl-lipoxin A4, N-acetyl--hydroxyproline; nalmefene hydrochloride monohydrate (SRD174)

Systemic treatments including: oral prednisolone; methotrexate; mycophenolate mofetil; biological therapies (omalizumab; mepolizumab); intravenous immunoglobulin; montelukast

Oral antihistamines

Other less commonly used interventions including: oral pimecrolimus; oral naltrexone; autologous blood therapy; tandospirone citrate; full spectrum light therapy; excimer laser; nitrazepam;

theophylline; topical salbutamol; papaverine and suplatast tosilate

Complementary therapies including: Chinese Herbal treatment; hypnotherapy; massage therapy; aromatherapy; acupuncture; acupressure; and other herbal treatments

\begin{tabular}{|l|l|}
\hline $\begin{array}{l}\text { Number of } \\
\text { trials }\end{array}$ & $\begin{array}{l}\text { Number of } \\
\text { participants }\end{array}$ \\
\hline $20^{150-168}$ & 1664 \\
\hline $13^{169-181}$ & 711 \\
\hline $33^{182-214}$ & 2447 \\
\hline $3^{215-217}$ & 125 \\
\hline $2^{22,218}$ & 660 \\
\hline $5^{219-223}$ & 153 \\
\hline $3^{224-226}$ & 66 \\
\hline $4^{227-230}$ & 202 \\
\hline $27^{231-257}$ & 1340 \\
& \\
\hline $22^{258-279}$ & 900 \\
\hline $29^{278,280-307}$ & 4201 \\
\hline $14^{308-319}$ & 481 \\
\hline $17^{320-335}$ & 604 \\
\hline
\end{tabular}

Paller, A. S. et al. Fluocinolone acetonide $0.01 \%$ in peanut oil: therapy for childhood atopic dermatitis, even in patients who are peanut sensitive. Journal of the American Academy of Dermatology 48, 569-577 (2003).

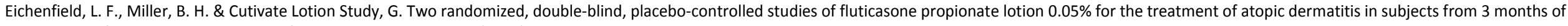
age. Journal of the American Academy of Dermatology 54, 715-717 (2006).

Hebert, A. A. et al. Safety and efficacy of desonide hydrogel 0.05\% in pediatric subjects with atopic dermatitis. Journal of drugs in dermatology : JDD 6, 175-181 (2007).

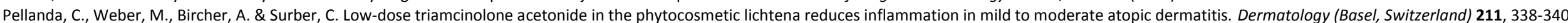
(2005).

Abramovits, W. \& Oquendo, M. Hydrocortisone butyrate 0.1\% lipocream in pediatric patients with atopic dermatitis. Skinmed, $72-79$ (2010). <http://www.mrw.interscience.wiley.com/cochrane/clcentral/articles/219/CN$00749219 /$ frame.html $>$.

Matheson, R. et al. Hydrocortisone butyrate $0.1 \%$ lotion in the treatment of atopic dermatitis in pediatric subjects. Journal of drugs in dermatology : JDD 7, 266-271 (2008).

Del Rosso, J. Q., Bhambri, S., Del Rosso, J. Q. \& Bhambri, S. Daily application of fluocinonide 0.1\% cream for the treatment of atopic dermatitis. The Journal of Clinical \& Aesthetic Dermatology 2, 24-32 (2009).

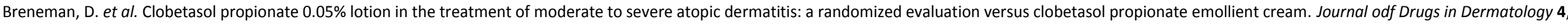
330-336 (2005).

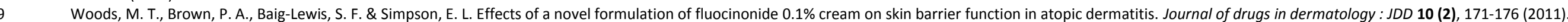
Brock, W. \& Cullen, S. I. Triamcinolone acetonide in flexible collodion for dermatologic therapy. Archives of Dermatology 96, 193-194 (1967).

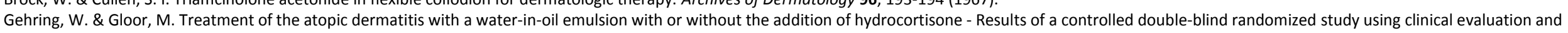
bioengineering methods. [German]. H+G Zeitschrift fur Hautkrankheiten 71 (7), 554-560 (1996).

Vanderploeg, D. E. Betamethasone dipropionate ointment in the treatment of psoriasis and atopic dermatitis: a double blind study. Southern Medical Journal 69 (7), 862-863 (1976).

Roth, H. L. \& Brown, E. P. Hydrocortisone valerate. Double-blind comparison with two other topical steroids. Cutis 21 (5), 695-698 (1978).

Sudilovsky, A., Muir, J. G. \& Bocobo, F. C. A comparison of single and multiple applications of halcinonide cream. International Journal of Dermatology 20 (9), $609-613$ (1981).

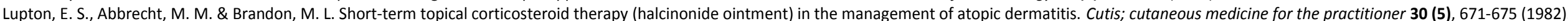
Sefton, J., Loder, J. S. \& Kyriakopoulos, A. A. Clinical evaluation of hydrocortisone valerate 0.2\% ointment. Clinical Therapeutics 6 (3), 282-293 (1984).

Wahlgren, C. F., Hagermark, O., Bergstrom, R. \& Hedin, B. Evaluation of a new method of assessing pruritus and antipruritic drugs. Skin Pharmacology 1 (1), 3-13 (1988)

Stalder, J. F. et al. Local steroid therapy and bacterial skin flora in atopic dermatitis. British Journal of Dermatology 131, 536-540 (1994).

Lebwohl, M. Efficacy and safety of fluticasone propionate ointment, 0.005\%, in the treatment of eczema. Cutis; cutaneous medicine for the practitioner 57 (2 Suppl), $62-68$ (1996). 
Sears, H. W., Bailer, J. W. \& Yeadon, A. Efficacy and safety of hydrocortisone buteprate $0.1 \%$ cream in patients with atopic dermatitis. Clinical Therapeutics 19, $710-719$ (1997).

Maloney, J. et al. Clobetasol propionate emollient 0.05\% in the treatment of atopic dermatitis. International Journal of Dermatology 37 (2), 142-144 (1998).

Salavec, M. \& Buckova, H. First experiences with 1\% Pimecrolimus cream therapy in prevention of atopic eczema flares in children (Czechoslovakian). Cesko-slovenska dermatologie 79, 3-7 (2004).

Zuberbier, T. et al. Steroid-sparing effect of pimecrolimus cream 1\% in children with severe atopic dermatitis. Dermatology (Basel, Switzerland) 215, 325-330 (2007).

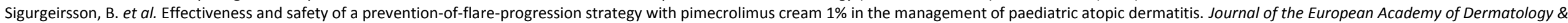
Venereology 22, 1290-1301 (2008).

Meurer, M. et al. Pimecrolimus cream in the long-term management of atopic dermatitis in adults: a six-month study. Dermatology (Basel, Switzerland) 205, 271-277, doi:65863 (2002).

Gollnick, H. et al. Pimecrolimus cream 1\% in the long-term management of adult atopic dermatitis: prevention of flare progression. A randomized controlled trial. British Journal of Dermatology 158, 1083-1093 (2008). Hoeger, P. H. et al. The treatment of facial atopic dermatitis in children who are intolerant of, or dependent on, topical corticosteroids: A randomized, controlled clinical trial. British Journal of Dermatology 160, $415-422$, doi:http://dx.doi.org/10.1111/j.1365-2133.2008.08928.x (2009).

Murrell, D. F.

Leung, D. Y. et al. Effects of pimecrolimus cream $1 \%$ in the treatment of patients with atopic dermatitis who demonstrate a clinical insensitivity to topical corticosteroids: a randomized, multicentre vehicle-controlled trial. British Journal of Dermatology 161, 435-443 (2009).

Ho, V. C. et al. Safety and efficacy of nonsteroid pimecrolimus cream 1\% in the treatment of atopic dermatitis in infants. Journal of Pediatrics 142, 155-162 (2003).

Eichenfield, L. F. et al. Safety and efficacy of pimecrolimus (ASM 981) cream $1 \%$ in the treatment of mild and moderate atopic dermatitis in children and adolescents. [see comment]. Journal of the American Academy of Dermatology 46, 495-504 (2002).

Kaufmann, R. et al. Onset of pruritus relief with pimecrolimus cream 1\% in adult patients with atopic dermatitis: a randomized trial. Allergy 61, 375-381 (2006).

Kaufmann, R. et al. Onset of action of pimecrolimus cream $1 \%$ in the treatment of atopic eczema in infants. Journal of Allergy and Clinical Immunology 114, 1183-1188 (2004).

Fowler, J., Johnson, A., Chen, M. \& Abrams, K. Improvement in pruritus in children with atopic dermatitis using pimecrolimus cream 1\%. Cutis; cutaneous medicine for the practitioner 79, 65-72 (2007).

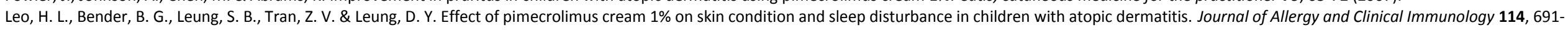
693 (2004).

Aschoff, R. et al. Skin physiological parameters confirm the therapeutic efficacy of pimecrolimus cream 1\% in patients with mild-to-moderate atopic dermatitis. Experimental Dermatology 18, 24-29 (2009).

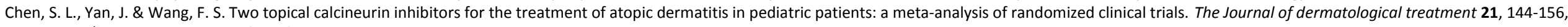
doi:10.3109/09546630903401470 (2010).

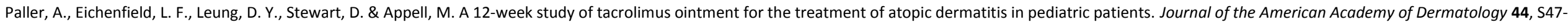
57 (2001).

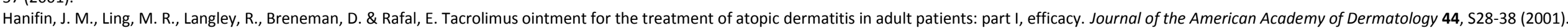
Chapman, M. S. et al. Tacrolimus ointment $0.03 \%$ shows efficacy and safety in pediatric and adult patients with mild to moderate atopic dermatitis. Journal of the American Academy of Dermatology 53 , S177-185, doi:10.1016/j.jaad.2005.04.061 (2005)

Dou, X. et al. [The impact of tacrolimus ointment on health-related quality of life of Chinese adult and pediatric patients with atopic dermatitis]. Journal of Clinical Dermatology 35, 50-52 (2006).

Clinical Therapeutics and Medicines 19, 569-595 (2003)

Rahman, M. F. et al. Efficacy of topical tacrolimus in atopic dermatitis. Journal of Pakistan Association of Dermatologists 18, 84-92 (2008).

Granlund, H., Remitz, A., Kyllonen, H., Lauerma, A. I. \& Reitamo, S. Treatment of lichenified atopic eczema with tacrolimus ointment. Acta Derm-Venereol 81, 314-315 (2001).

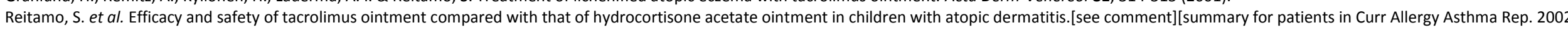
Jul;2(4):273-4; PMID: 12044259]. Journal of Allergy \& Clinical Immunology 109, 539-546 (2002).

Reitamo, S. et al. $0.03 \%$ Tacrolimus ointment applied once or twice daily is more efficacious than $1 \%$ hydrocortisone acetate in children with moderate to severe atopic dermatitis: results of a randomized double-blind controlled trial.[see comment]. British Journal of Dermatology 150, 554-562 (2004).

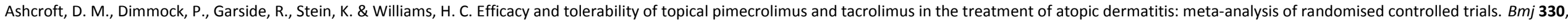
516, doi:10.1136/bmj.38376.439653.D3 (2005).

Doss, N. et al. Superiority of tacrolimus $0.1 \%$ ointment compared with fluticasone $0.005 \%$ in adults with moderate to severe atopic dermatitis of the face: results from a randomized, double-blind trial. British Journal of Dermatology 161, 427-434 (2009).

Paller, A. S. et al. Tacrolimus ointment is more effective than pimecrolimus cream with a similar safety profile in the treatment of atopic dermatitis: results from 3 randomized, comparative studies. Journal of the American Academy of Dermatology 52, 810-822, doi:10.1016/j.jaad.2004.12.038 (2005).

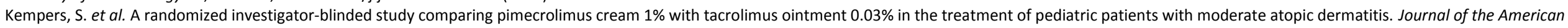
Academy of Dermatology 51, 515-525, doi:10.1016/j.jaad.2004.01.051 (2004).

Draelos, Z. et al. Pharmacokinetics of topical calcineurin inhibitors in adult atopic dermatitis: a randomized, investigator-blind comparison. Journal of the American Academy of Dermatology 53, 602-609,

doi:10.1016/j.jaad.2005.06.013 (2005).

Cury Martins, J. et al. Topical tacrolimus for atopic dermatitis. The Cochrane database of systematic reviews 7, Cd009864, doi:10.1002/14651858.CD009864.pub2 (2015). 

study. The British journal of dermatology 158, 801-807, doi:10.1111/j.1365-2133.2008.08436.x (2008).

Hanifin, J., Gupta, A. K. \& Rajagopalan, R. Intermittent dosing of fluticasone propionate cream for reducing the risk of relapse in atopic dermatitis patients. British Journal of Dermatology 147, 528-537 (2002).

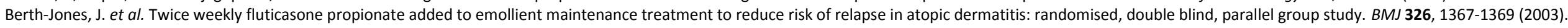
Glazenburg, E. J., Wolkerstorfer, A., Gerretsen, A. L., Mulder, P. G. \& Oranje, A. P. Efficacy and safety of fluticasone propionate $0.005 \%$ ointment in the long-term maintenance treatment of children with atopic dermatitis: differences between boys and girls? Pediatric allergy and immunology : official publication of the European Society of Pediatric Allergy and Immunology 20, 59-66 (2009).

Schmitt, J., von Kobyletzki, L., Svensson, A. \& Apfelbacher, C. Efficacy and tolerability of proactive treatment with topical corticosteroids and calcineurin inhibitors for atopic eczema: systematic review and meta-analysis of randomized controlled trials. The British journal of dermatology 164, 415-428, doi:10.1111/j.1365-2133.2010.10030.x (2011).

Journal of the Amer. Intermittent therapy for flare prevention and long-ter

Joura of the American Academy of Dermatology $58,990-999$ (2008).

(2008)

Wollenberg, A. et al. Proactive treatment of atopic dermatitis in adults with 0.1\% tacrolimus ointment.[republished in Allergy. 2008 Jul;63(7):742-50; PMID: 18592619]. Allergy 63, 742-750 (2008).

Takeuchi. A Randomized, Open-Label, Multicenter Trial of Topical Tacrolimus for the Treatment of Pruritus in Patients with Atopic Dermatitis. Annals of Dermatology (2012).

Bangert. Clinical and cytological effects of pimecrolimus cream $1 \%$ after resolution of active atopic dermatitis lesions by topical corticosteroids: A randomised controlled trial. Dermatology (2011).

Munro, C. S., Levell, N. J., Shuster, S. \& Friedmann, P. S. Maintenance treatment with cyclosporin in atopic eczema. The British journal of dermatology 130, 376-380 (1994).

van Joost, T. et al. Cyclosporin in atopic dermatitis: a multicentre placebo-controlled study. The British journal of dermatology 130, 634-640 (1994).

Sowden, J. M. et al. Double-blind, controlled, crossover study of cyclosporin in adults with severe refractory atopic dermatitis. Lancet (London, England) 338, 137-140 (1991).

Wahlgren, C. F., Scheynius, A. \& Hagermark, O. Antipruritic effect of oral cyclosporin A in atopic dermatitis. Acta dermato-venereologica 70, 323-329 (1990).

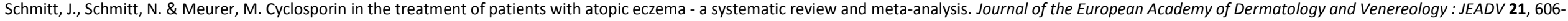
619, doi:10.1111/j.1468-3083.2006.02023.x (2007).

Meggitt, S. J., Gray, J. C. \& Reynolds, N. J. Azathioprine dosed by thiopurine methyltransferase activity for moderate-to-severe atopic eczema: a double-blind, randomised controlled trial. Lancet 367, 839-846,

doi:10.1016/s0140-6736(06)68340-2 (2006).

Berth-Jones, J. et al. Azathioprine in severe adult atopic dermatitis: a double-blind, placebo-controlled, crossover trial. British Journal of Dermatology 147, 324-330 (2002).

Schram, M. E. et al. Off-label use of azathioprine in dermatology: a systematic review. Arch Dermatol 147, 474-488, doi:10.1001/archdermatol.2011.79 (2011)

Jekler, J. \& Larko, O. UVB phototherapy of atopic dermatitis. The British journal of dermatology 119, 697-705 (1988).

Reynolds, N. J., Franklin, V., Gray, J. C., Diffey, B. L. \& Farr, P. M. Narrow-band ultraviolet B and broad-band ultraviolet A phototherapy in adult atopic eczema: a randomised controlled trial. Lancet 357, 2012-2016 (2001).

Gambichler, T., Breuckmann, F., Boms, S., Altmeyer, P. \& Kreuter, A. Narrowband UVB phototherapy in skin conditions beyond psoriasis. J Am Acad Dermatol 52, 660-670, doi:10.1016/j.jaad.2004.08.047 (2005).

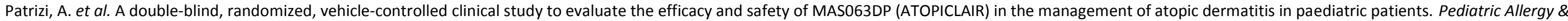
Immunology 19, 619-625 (2008).

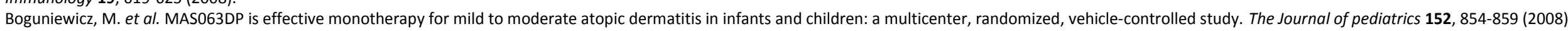

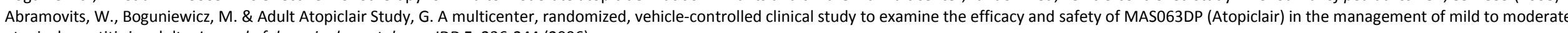
atopic dermatitis in adults. Journal of drugs in dermatology : JDD 5, 236-244 (2006).

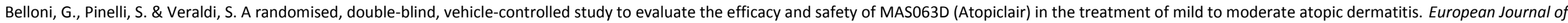
Dermatology 15, 31-36 (2005)

Miller, D. W. et al. An over-the-counter moisturizer is as clinically effective as, and more cost-effective than, prescription barrier creams in the treatment of children with mild-to-moderate atopic dermatitis: a randomized, controlled trial. J Drugs Dermatol 10, 531-537 (2011).

Span, L. et al. Intensive daycare for young adults with atopic eczema. Nederlands Tijdschrift voor Dermatologie \& Venereologie 11, 279-283 (2001).

Shaw, M., Morrell, D. S. \& Goldsmith, L. A. A study of targeted enhanced patient care for pediatric atopic dermatitis (STEP PAD). Pediatric Dermatology 25, 19-24 (2008).

Staab, D. et al. Age related, structured educational programmes for the management of atopic dermatitis in children and adolescents: multicentre, randomised controlled trial.[see comment]. BMJ 332, 933-938 (2006).

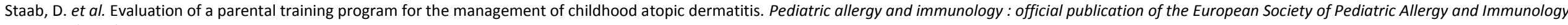
13, 84-90 (2002).

Grillo, M., Gassner, L., Marshman, G., Dunn, S. \& Hudson, P. Pediatric atopic eczema: the impact of an educational intervention. Pediatric Dermatology 23, 428-436 (2006).

Futamura M., M. I., Hayashi K., Ohya Y., Ito K. Effects of a short-term parental education program on childhood atopic dermatitis: A randomized controlled trial. Pediatric Dermatology, 438 - 443 (2013).

Kardorff, B. et al. Successful reduction of the SCORAD score by a short-time teaching method using a simplified skin model in children with atopic eczema in a 6-week comparison. Journal der Deutschen Dermatologischen Gesellschaft 1, 451-456 (2003)

Pickett, K., Loveman, E., Kalita, N., Frampton, G. K. \& Jones, J. Educational interventions to improve quality of life in people with chronic inflammatory skin diseases: systematic reviews of clinical effectiveness and costeffectiveness. Health Technol Assess 19, 1-176, doi:10.3310/hta19860 (2015).

Ersser, S. J. et al. Psychological and educational interventions for atopic eczema in children. Cochrane Database Syst Rev 1, CD004054, doi:10.1002/14651858.CD004054.pub3 (2014).

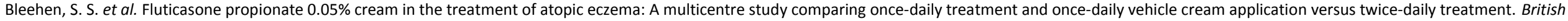
Journal of Dermatology 133 (4), 592-597 (1995).

Koopmans, B., Lasthein, A. B., Mork, N. J., Austad, J. \& Suhonen, R. E. Multicentre randomized doulble-blind study of Locoid Lipocream fatty cream twice daily versus Locoid Lipocream once daily and Locobase once daily. Journal of Dermatological Treatment. 6, 103-106 (1995). 


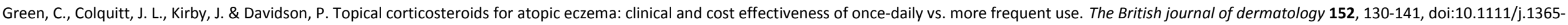
2133.2005.06410.x (2005)

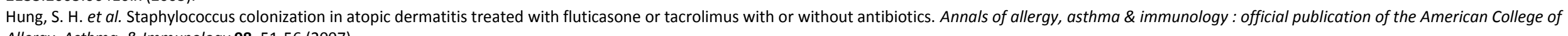
Allergy, Asthma, \& Immunology 98, $51-56$ (2007).

Gong, J. Q. et al. Skin colonization by Staphylococcus aureus in patients with eczema and atopic dermatitis and relevant combined topical therapy: a double-blind multicentre randomized controlled trial. British Journal of Dermatology 155, 680-687 (2006).

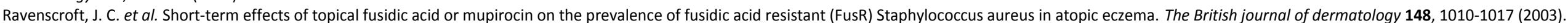

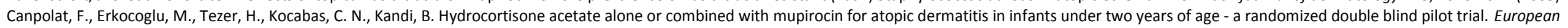
Review for Medical \& Pharmacological Sciences (2012).

Schuttelaar, M. L. \& Coenraads, P. J. A randomized, double-blind study to assess the efficacy of addition of tetracycline to triamcinolone acetonide in the treatment of moderate to severe atopic dermatitis. Journal of the European Academy of Dermatology \& Venereology 22, 1076-1082 (2008).

26, doi:10.1111/j.1365-2133.2010.09743.x (2010).

Rosenfeldt V. et al. Effect of probiotic Lactobacillus

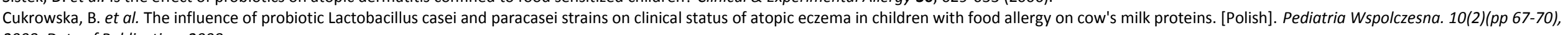
2008. Date of Publication: 2008.

101 Yesilova. Effect of Probiotics on the Treatment of Children with Atopic Dermatitis. Annals of Dermatology (2012).

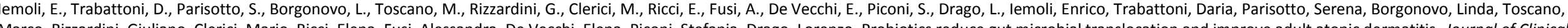

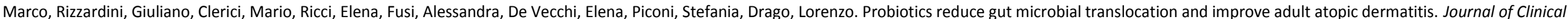
Gastroenterology (2012)

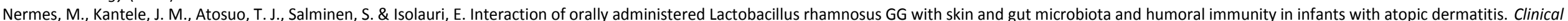
and Experimental Allergy 41 (3), 370-377, doi:http://dx.doi.org/10.1111/i.1365-2222.2010.03657.x.

Grüber, C. et al. Randomized, placebo-controlled trial of Lactobacillus rhamnosus GG as treatment of atopic dermatitis in infancy. Allergy 62, 1270-1276 (2007).

Brouwer, M. L. et al. No effects of probiotics on atopic dermatitis in infancy: a randomized placebo-controlled trial. Clinical \& Experimental Allergy 36, 899-906 (2006)

Folster-Holst, R. et al. Prospective, randomized controlled trial on Lactobacillus rhamnosus in infants with moderate to severe atopic dermatitis. British Journal of Dermatology 155, 1256-1261 (2006).

Viljanen, M. et al. Probiotics in the treatment of atopic eczema/dermatitis syndrome in infants: a double-blind placebo-controlled trial. Allergy 60, 494-500 (2005).

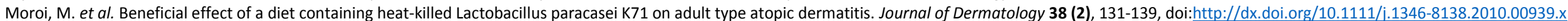

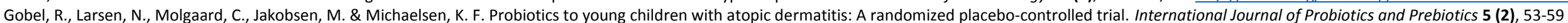

(2010).

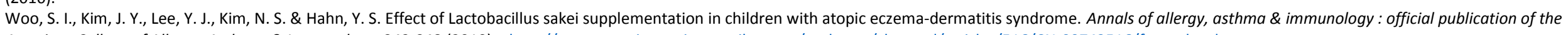
American College of Allergy, Asthma, \& Immunology, 343-348 (2010). <http://www.mrw.interscience.wiley.com/cochrane/clcentral/articles/516/CN-00742516/frame.html

Weston, S., Halbert, A., Richmond, P. \& Prescott, S. L. Effects of probiotics on atopic dermatitis: a randomised controlled trial. Arch Dis Child 90, 892-897, doi:10.1136/adc.2004.060673 (2005).

Torii, S. et al. Effects of oral administration of Lactobacillus acidophilus I-92 on the symptoms and serum markers of atopic dermatitis in children. International Archives of Allergy and Immunology 154 (3), 236-245,

doi:http://dx.doi.org/10.1159/000321110.

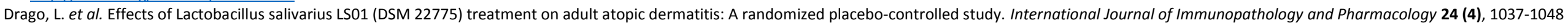

(2011).

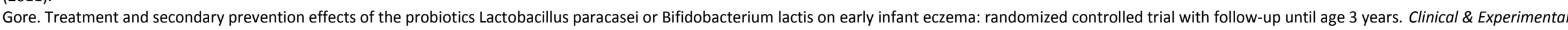
Allergy (2012).

Han, Y., Kim, B., Ban, J., Lee, J., Kim, B. J., Choi, B. S., Hwang, S., Ahn, K., Kim, J., Han, Youngshin, Kim, Bongjoon, Ban, Jeongsook, Lee, Jeongok, Kim, Beom Joon, Choi, Byung Sun, Hwang, Sehee, Ahn, Kangmo, Kim, Jihyun. A randomized trial of Lactobacillus plantarum CJLP133 for the treatment of atopic dermatitis. Pediatric Allergy \& Immunology (2012).

Isolauri, E., Arvola, T., Sutas, Y., Moilanen, E. \& Salminen, S. Probiotics in the management of atopic eczema. Clinical \& Experimental Allergy 30, 1604-1610 (2000).

Taniuchi, S. et al. Administration of Bifidobacterium to infants with atopic dermatitis: changes in fecal microflora and clinical symptoms. Journal of Applied Research 5, 387-396 (2005).

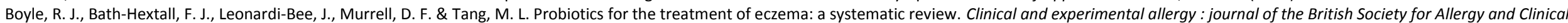
Immunology 39, 1117-1127, doi:10.1111/j.1365-2222.2009.03305.x (2009).

Takwale, A. et al. Efficacy and tolerability of borage oil in adults and children with atopic eczema: randomised, double blind, placebo controlled, parallel group trial. BMJ (Clinical research ed.) 327, 1385 (2003). Bahmer, F. A. \& Schäfer, J. [Treatment of atopic dermatitis with borage seed oil (Glandol)--a time series analytic study]. Kinderarztliche Praxis 60, 199-202 (1992).

Borrek, S., Hildebrandt, A. \& Forster, J. Gamma-linolenic-acid-rich borage seed oil capsules in children with atopic dermatitis. A placebo-controlled double-blind study. [German]. Klinische Padiatrie 209 (3), 100-104 (1997). Buslau, M. \& Thaci, D. Atopic dermatitis: Borage oil for systemic therapy. [German]. Zeitschrift fur Dermatologie 182 (3), 131-132+134-136 (1996).

Henz, B. M. et al. Double-blind, multicentre analysis of the efficacy of borage oil in patients with atopic eczema. British Journal of Dermatology 140, 685-688 (1999).

Valsecchi, R., Di Landro, A., Pansera, B. \& Reseghetti, A. Gammalinolenic acid in the treatment of atopic dermatitis [1]. Journal of the European Academy of Dermatology and Venereology 7 (1), 77-79 (1996).

Senapati, S., Banerjee, S. \& Gangopadhyay, D. N. Evening primrose oil is effective in atopic dermatitis: a randomized placebo-controlled trial. Indian Journal of Dermatology, Venereology \& Leprology 74, 447-452 (2008). Bamford, J. T. et al. Oral evening primrose oil and borage oil for eczema. (2013). 


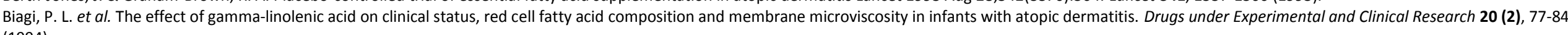
(1994).

Bordoni, A. et al. Evening primrose oil (Efamol) in the treatment of children with atopic eczema. Drugs under Experimental and Clinical Research 14 (4), 291-297 (1988).

Hederos, C. A. \& Berg, A. Epogam evening primrose oil treatment in atopic dermatitis and asthma. Archives of Disease in Childhood 75 (6), $494-497$ (1996).

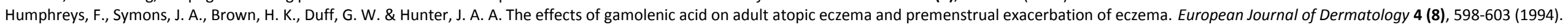
Mayser, P. et al. A double-blind, randomized, placebo-controlled trial of n-3 versus n-6 fatty acid-based lipid infusion in atopic dermatitis. Jpen: Journal of Parenteral \& Enteral Nutrition 26, 151-158 (2002). Bjorneboe, A., Soyland, E., Bjorneboe, G. E., Rajka, G. \& Drevon, C. A. Effect of $n-3$ fatty acid supplement to patients with atopic dermatitis. Journal of Internal Medicine Supplement 731, 233-236 (1989). Gimenez-Arnau, A. Effects of linoleic acid supplements on atopic dermatitis. Advances in Experimental Medicine and Biology 433, 285-289 (1997).

Soyland, E. et al. Dietary supplementation with very long-chain n-3 fatty acids in patients with atopic dermatitis. A double-blind, multicentre study. British Journal of Dermatology 130 (6), $757-764$ (1994). Koch, C. et al. Docosahexaenoic acid (DHA) supplementation in atopic eczema: a randomized, double-blind, controlled trial. The British journal of dermatology 158, 786-792, doi:10.1111/j.1365-2133.2007.08430.x (2008). Callaway, J. et al. Efficacy of dietary hempseed oil in patients with atopic dermatitis. Journal of Dermatological Treatment 16, 87-94 (2005).

Lovell, C. R., Burton, J. L. \& Horrobin, D. F. Treatment of atopic eczema with evening primrose oil. Lancet 1, 278 (1981).

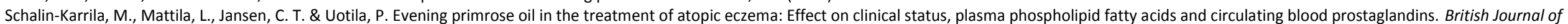
Dermatology 117 (1), 11-19 (1987).

Wright, S. \& Burton, J. L. Oral evening-primrose-seed oil improves atopic eczema. Lancet 2 (8308), 1120-1122 (1982).

Bamford, J. T. et al. Oral evening primrose oil and borage oil for eczema. Cochrane Database Syst Rev 4, CD004416, doi:10.1002/14651858.CD004416.pub2 (2013).

Foelster Holst, R. et al. The novel protease inhibitor SRD441 ointment is not effective in the treatment of adult subjects with atopic dermatitis: results of a randomized, vehicle-controlled study. Allergy $65,1594-1599$, doi:http://dx.doi.org/10.1111/j.1398-9995.2010.02417.x (2010).

Tripodi, S. et al. Lack of efficacy of topical furfuryl palmitate in pediatric atopic dermatitis: A randomized double-blind study. Journal of Investigational Allergology and Clinical Immunology 19, 204-209 (2009).

Thomas, K. S. et al. A randomised controlled trial of ion-exchange water softeners for the treatment of eczema in children. PLoS medicine 8, e1000395, doi:10.1371/journal.pmed.1000395 (2011).

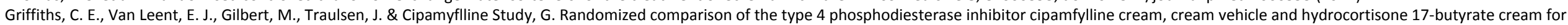
the treatment of atopic dermatitis. British Journal of Dermatology 147, 299-307 (2002).

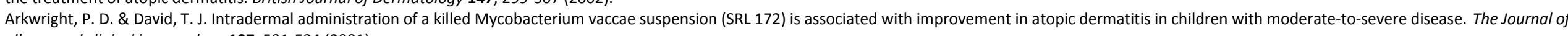
allergy and clinical immunology 107, 531-534 (2001).

Arkwright, P. D. \& David, T. J. Effect of Mycobacterium vaccae on atopic dermatitis in children of different ages. The British journal of dermatology 149, 1029-1034 (2003).

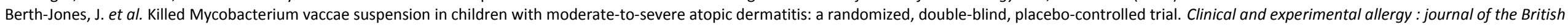
Society for Allergy and Clinical Immunology 36, 1115-1121, doi:10.1111/j.1365-2222.2006.02558.x (2006).

Brothers, S., Asher, M. I., Jaksic, M. \& Stewart, A. W. Effect of a Mycobacterium vaccae derivative on paediatric atopic dermatitis: A randomized, controlled trial. Clinical and Experimental Dermatology 34, 770-775, doi:http://dx.doi.org/10.1111/j.1365-2230.2008.03153.x (2009).

Kantor, I. et al. Efficacy and safety of emollients as adjunctive agents in topical corticosteroid therapy for atopic dermatitis. Today's Therapeutic Trends 11 (3), 157-166 (1993)

Hanifin, J. M. et al. Effects of a low-potency corticosteroid lotion plus a moisturizing regimen in the treatment of atopic dermatitis. Current Therapeutic Research - Clinical and Experimental 59 (4), 227-233 (1998).

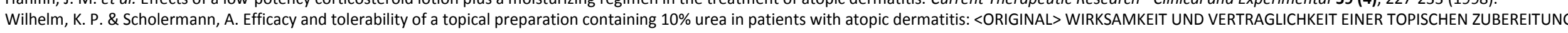

MIT 10\% UREA (LACERAN (R)) SALBE 10\% UREA) BEI NEURODERMITIS. Aktuelle Dermatologie 24, 26-30 (1998).

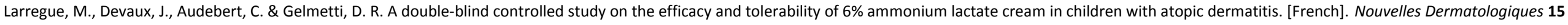
(10), 720-721 (1996)

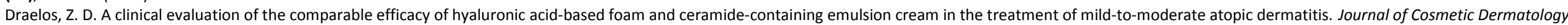
10 (3), 185-188, doi:http://dx.doi.org/10.1111/j.1473-2165.2011.00568.x (2011).

Draelos, Z. D. \& Draelos, Z. D. An evaluation of prescription device moisturizers. Journal of Cosmetic Dermatology 8, 40-43 (2009)

Wiren, K. et al. Treatment with a barrier-strengthening moisturizing cream delays relapse of atopic dermatitis: A prospective and randomized controlled clinical trial. Journal of the European Academy of Dermatology and Venereology 23, 1267-1272, doi:http://dx.doi.org/10.1111/j.1468-3083.2009.03303.x (2009).

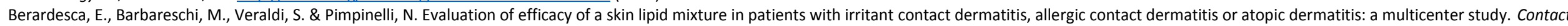
Dermatitis 45, 280-285 (2001).

Sugarman, J. L., Parish, L. C., Sugarman, J. L. \& Parish, L. C. Efficacy of a lipid-based barrier repair formulation in moderate-to-severe pediatric atopic dermatitis. Journal of Drugs in Dermatology: JDD 8, 1106-1111 (2009).

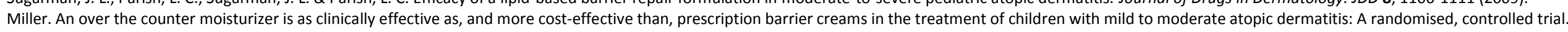
Journal of Drugs in Dermatology (2011).

Simpson. A New Body Moisturizer Increases Skin Hydration and Improves Atopic Dermatitis Symptoms Among Children and Adults. Journal of Drugs in Dermatology (2011).

Grimalt, R., Mengeaud, V., Cambazard, F. \& Study Investigators', G. The steroid-sparing effect of an emollient therapy in infants with atopic dermatitis: a randomized controlled study. Dermatology 214, 61-67 (2007).

Giordano-Labadie, F., Cambazard, F., Guillet, G., Combemale, P. \& Mengeaud, V. Evaluation of a new moisturizer (Exomega milk) in children with atopic dermatitis. Journal of Dermatological Treatment 17, 78-81 (2006).

Bissonnette, R. et al. A double-blind study of tolerance and efficacy of a new urea-containing moisturizer in patients with atopic dermatitis. Journal of cosmetic dermatology, 16-21 (2010).

$<$ http://www.mrw.interscience.wiley.com/cochrane/clcentral/articles/896/CN-00751896/frame.html . 
Msika, P. et al. New Emollient with Topical Corticosteroid-Sparing Effect in Treatment of Childhood Atopic Dermatitis: SCORAD and Quality of Life Improvement. Pediatric Dermatology 25, 606-612 (2008).

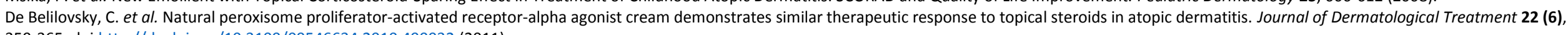

359-365, doi:http://dx.doi.org/10.3109/09546634.2010.499932 (2011).

Loden, M. et al. Instrumental and dermatologist evaluation of the effect of glycerine and urea on dry skin in atopic dermatitis. Skin Research and Technology 7, 209-213 (2001).

Shibata, R. et al. Clinical effects of kestose, a prebiotic oligosaccharide, on the treatment of atopic dermatitis in infants. Clinical \& Experimental Allergy 39, 1397-1403 (2009).

Ghanei. Effectiveness of prebiotic in atopic dermatitis reduction in 7 to 24 months old children living in Isfahan. Journal of Isfahan Medical School (2011).

van $\operatorname{der}$ Aa, L. B. et al. Effect of a new synbiotic mixture on atopic dermatitis in infants: a randomized-controlled trial. Clinical \& Experimental Allergy 40, 795-804 (2010).

Passeron, T., Lacour, J. P., Fontas, E. \& Ortonne, J. P. Prebiotics and synbiotics: two promising approaches for the treatment of atopic dermatitis in children above 2 years. Allergy 61, 431-437 (2006).

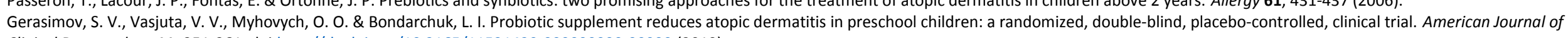
Clinical Dermatology 11, 351-361, doi:http://dx.doi.org/10.2165/11531420-000000000-00000 (2010).

Hattori, K. et al. [Effects of administration of bifidobacteria on fecal microflora and clinical symptoms in infants with atopic dermatitis]. [Japanese]. Arerugi - Japanese Journal of Allergology 52, 20-30 (2003).

Murosaki, S. et al. Effects of intake of syrup supplemented with nigerooligosaccharides and heat-killed Lactobacillus plantarum L-137 on skin symptom and immune function in patients with atopic dermatitis. [Japanese]. Japanese Pharmacology and Therapeutics. 34(10)(pp 1087-1096), 2006. Date of Publication: 2006.

Japanese Pharmacology and Therapeutics. 34(10)(pp 1087-1096), 2006. Date of Publication: 2006.
Farid, R., Ahanchian, H., Jabbari, F. \& Moghiman, T. Effect of a new synbiotic mixture on atopic dermatitis in children: A randomized-controlled trial. Iranian Journal of Pediatrics 21 (2), 225-230 (2011).

Shafiei. Synbiotics could not Reduce the Scoring of Childhood Atopic Dermatitis (SCORAD): A Randomised Double Blind Placebo-Controlled Trial. Iranian Journal of Allergy, Asthma and Immunology (2011).

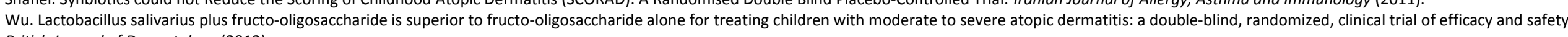
British Journal of Dermatology (2012).

Immunology $18,594-598$ ch (2007).

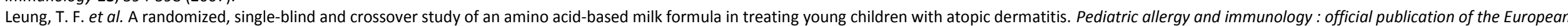

Society of Pediatric Allergy and Immunology 15, 558-561 (2004).

Jin. Partially hydrolyzed cow's milk formula has a therapeutic effect on the infants with mild to moderate atopic dermatitis: a randomized, double-blind study. Pediatric Allergy \& Immunology (2011).

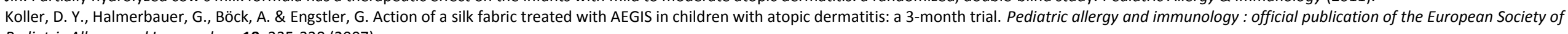
Pediatric Allergy and Immunology 18, 335-338 (2007).

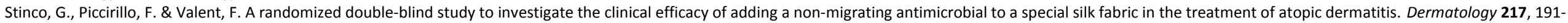
195 (2008).

Fontanini C., B. I., Monasta L., Longo G. DermaSilk in long-term control of infantile atopic dermatitis: A double blind randomized controlled trial. Giornale Italiano di Dermatologia e Venereologia, 293 - 297 (2013). Ozawa, M. et al. Effect of underwear made from MEDIELE on skin barrier function of atopic dermatitis patients in winter season. [Japanese]. Skin Research. 7(4)(pp 475-481), 2008. Date of Publication: August 2008.

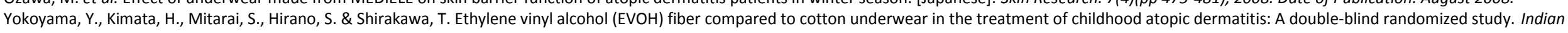
Pediatrics 46, 611-614 (2009).

Gauger, A. et al. Efficacy and functionality of silver-coated textiles in patients with atopic eczema. J Eur Acad Dermatol Venereol 20, 534-541, doi:10.1111/j.1468-3083.2006.01526.x (2006).

Juenger, M. et al. Efficacy and safety of silver textile in the treatment of atopic dermatitis (AD). Current medical research and opinion 22, 739-750 (2006).

Kim, B. \& Kim, C. Effect of mattress and pillow encasings on children with atopic dermatitis. Journal of Allergy \& Clinical Immunology 115, S101-S101 (2005).

Moore, E., Williams, A., Manias, E. \& Varigos, G. Nurse-led clinics reduce severity of childhood atopic eczema: a review of the literature. The British journal of dermatology 155, 1242-1248 (2006).

Schuttelaar, M. L., Vermeulen, K. M., Drukker, N. \& Coenraads, P. J. A randomized controlled trial in children with eczema: nurse practitioner vs. dermatologist. The British journal of dermatology, 162-170 (2010).

$<$ http://www.mrw.interscience.wiley.com/cochrane/clcentral/articles/334/CN-00742334/frame.html>.

Blessmann Weber, M. et al. Improvement of pruritus and quality of life of children with atopic dermatitis and their families after joining support groups. Journal of the European Academy of Dermatology and Venereology. 22(8)(pp 992-997), 2008. Date of Publication: August 2008.

Van Os-Medendorp, H. et al. E-health in caring for patients with atopic dermatitis: A randomized controlled cost-effectiveness study of internet-guided monitoring and online self-management training. British Journal of Dermatology 166 (5), 1060-1068, doi:http://dx.doi.org/10.1111/j.1365-2133.2012.10829.x (2012).

Schut C., W. U., Tews N., Gieler U., Deinzer R., Kupfer J. Psychophysiological effects of stress management in patients with atopic dermatitis: A randomized controlled trial. Acta Dermato-Venereologica (2013).

Byremo, G., Rød, G. \& Carlsen, K. H. Effect of climatic change in children with atopic eczema. Allergy 61, 1403-1410 (2006).

Ricci, G. et al. Effect of house dust mite avoidance measures in children with atopic dermatitis. British Journal of Dermatology 143, 379-384 (2000).

Gutgesell, C. et al. Double-blind placebo-controlled house dust mite control measures in adult patients with dermatitis. British Journal of Dermatology 145, 70-74 (2001).

Oosting, A. J. et al. Effect of mattress encasings on atopic dermatitis outcome measures in a double-blind, placebo-controlled study: the Dutch mite avoidance study. Journal of Allergy \& Clinical Immunology $110,500-506$ (2002).

Sagransky, M. J. et al. A randomized controlled pilot study of the effects of an extra office visit on adherence and outcomes in atopic dermatitis. Archives of Dermatology 146, 1428-1430 (2010).

Glover, M. T. \& Atherton, D. J. A double-blind controlled trial of hyposensitization to Dermatophagoides pteronyssinus in children with atopic eczema. Clinical and Experimental Allergy 22 (4), 440-446 (1992).

Galli, E. et al. Use of a specific oral hyposensitization therapy to Dermatophagoides pteronyssinus in children with atopic dermatitis. Allergologia et immunopathologia 22, 18-22 (1994).

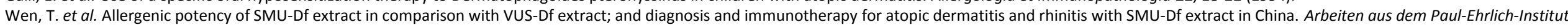
(Bundesamt fur Sera und Impfstoffe) zu Frankfurt a.M (85), 217-227 (1992). 
Diepgen, T. L., Salzer, B., Tepe, A. \& Hornstein, O. P. A study of skin irritations by textiles under standardized sweating conditions in patients with atopic eczema. Melliand English 12, 268 (1995).

Diepgen, T. L., Stabler, A. \& Hornstein, O. P. Irritation from textiles in atopic eczema and controls. [German]. H+G Zeitschrift fur Hautkrankheiten 65 (10), 907-910 (1990).

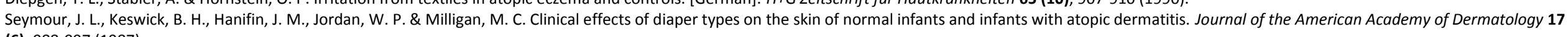
(6), 988-997 (1987).

(2002).

Chinn, D. J.,

(2002).

Moore, E. J., Williams, A., Manias, E., Varigos, G. \& Donath, S. Eczema workshops reduce severity of childhood atopic eczema. Australasian Journal of Dermatology 50, 100-106, doi:http://dx.doi.org/10.1111/j.14400960.2009.00515.x (2009).

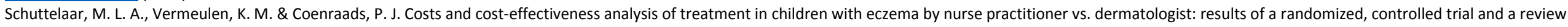
of international costs. British Journal of Dermatology 165, 600-611, doi:10.1111/j.1365-2133.2011.10470.x (2011).

Armstrong. Online video improves clinical outcomes in adults with atopic dermatitis: A randomized controlled trial. Journal of the American Academy of Dermatology (2011).

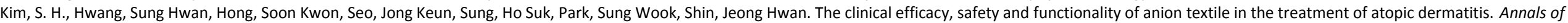
dermatology (2012).

Adachi, J., Sumitsuzi, H., Endo, K., Fukuzumi, T. \& Aoki, T. Evaluation of the effect of short-term application of deep sea water on atopic dermatitis. [Japanese]. Arerugi = [Allergy] 47 (1), 57-60 (1998).

Melin, L., Frederiksen, T., Noren, P. \& Swebilius, B. G. Behavioural treatment of scratching in patients with atopic dermatitis. British Journal of Dermatology 115 (4), $467-474$ (1986).

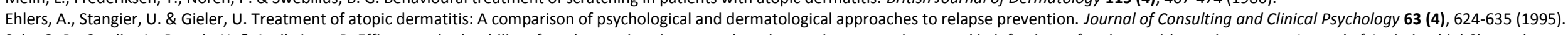

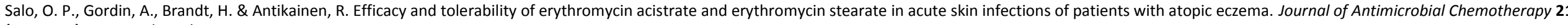
(SUPPL. D), 101-106 (1988)

Weinberg, E., Fourie, B., Allmann, B. \& Toerien, A. The use of cefadroxil in superinfected atopic dermatitis. Current Therapeutic Research - Clinical and Experimental 52 (5), $671-676$ (1992).

Ewing, C. I. et al. Flucloxacillin in the treatment of atopic dermatitis. British Journal of Dermatology 138 (6), 1022-1029 (1998).

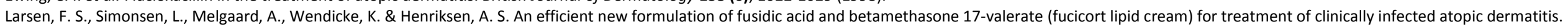
Acta Dermato-Venereologica 87, 62-68 (2007).

Foelster-Holst, R., Nagel, F., Zoellner, P. \& Spaeth, D. Efficacy of crisis intervention treatment with topical corticosteroid prednicarbat with and without partial wet-wrap dressing in atopic dermatitis. Dermatology (Basel, Switzerland) 212, 66-69 (2006).

Hindley, D., Galloway, G., Murray, J. \& Gardener, L. A randomised study of "wet wraps" versus conventional treatment for atopic eczema.[see comment]. Archives of Disease in Childhood 91, 164-168 (2006).

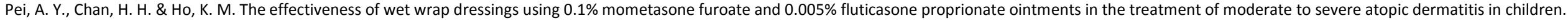
Pediatric Dermatology 18, 343-348 (2001).

Beattie, P. \& al., e. A pilot study on the use of wet wraps in moderate atopic eczema. British Association of Dermatologists 83rd Annual Meeting. Abstract O-8. British Journal of Dermatology 149, 4 (2003).

Schnopp, C. et al. Topical steroids under wet-wrap dressings in atopic dermatitis--a vehicle-controlled trial. Dermatology 204, 56-59 (2002).

Shibagaki, N. et al. [Clinical efficacy of bath additive containing a diamide derivative in patients with atopic dermatitis]. Nishinihon Journal of Dermatology 67, 152-159 (2005).

Harper, J. Double-blind comparison of an antiseptic oil-based bath additive (Oilatum Plus) with regular Oilatum (Oilatum Emollient) for the treatment of atopic eczema. Round Table Series - Royal Society of Medicine, $42-47$

(1995).

Holland, K. T., Bojar, R. A. \& Cunliffe, W. J. A comparison of the effect of treatment of atopic eczema with and without antimicrobial compounds. Round Table Series - Royal Society of Medicine (37), 34-41 (1995).

Lintu, P., Savolainen, J., Kortekangas-Savolainen, O. \& Kalimo, K. Systemic ketoconazole is an effective treatment of atopic dermatitis with IgE-mediated hypersensitivity to yeasts. Allergy 56, 512-517 (2001).

Back \& Bartosik, J. Systemic ketoconazole for yeast allergic patients with atopic dermatitis. [see comment]. Journal of the European Academy of Dermatology \& Venereology 15, 34-38 (2001).

Broberg, A. \& Faergemann, J. Topical antimycotic treatment of atopic dermatitis in the head/neck area. A double-blind randomised study. Acta Dermato-Venereologica 75 (1), $46-49$ (1995).

Wong, A. W., Hon, E. K. \& Zee, B. Is topical antimycotic treatment useful as adjuvant therapy for flexural atopic dermatitis: randomized, double-blind, controlled trial using one side of the elbow or knee as a control. International Journal of Dermatology 47, 187-191 (2008).

Anstey, A. \& Wilkinson, J. D. Lithium succinate ointment in the treatment of atopic eczema[1]. Journal of Dermatological Treatment 2 (1), 37-38 (1991).

Palombo, P. et al. A special pill-mask to re-hydrate the skin affected by atopic dermatitis. Journal of Applied Cosmetology 22, 87-97 (2004).

Stern, T. \& Bayerl, C. Black seed oil ointment - A new approach for the treatment of atopic dermatitis? Aktuelle Dermatologie 28, 74-79 (2002).

Lee, J., Jung, E., Koh, J., Kim, Y. S. \& Park, D. Effect of rosmarinic acid on atopic dermatitis. The Journal of dermatology 35, 768-771 (2008).

Thumm, E. J., Stoss, M., Bayerl, C. \& Schurholz, T. h. Randomized trial to study efficacy of a $20 \%$ and $10 \%$ Hippophae rhamnoides containing creme used by patients with mild to intermediate atopic dermatitis. Aktuelle Dermatologie 26, 285-290 (2000)

Korting, H. C., Schollmann, C., Cholcha, W., Wolff, L. \& Collaborative Study, G. Efficacy and tolerability of pale sulfonated shale oil cream $4 \%$ in the treatment of mild to moderate atopic eczema in children: a multicentre, randomized vehicle-controlled trial. Journal of the European Academy of Dermatology \& Venereology 24, 1176-1182, doi:http://dx.doi.org/10.1111/i.1468-3083.2010.03616.x (2010).

Guéniche, A. et al. Improvement of atopic dermatitis skin symptoms by Vitreoscilla filiformis bacterial extract. European journal of dermatology : EJD 16, 380-384 (2006).

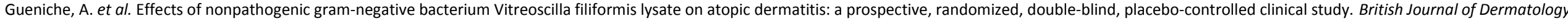
159, $1357-1363(2008)$

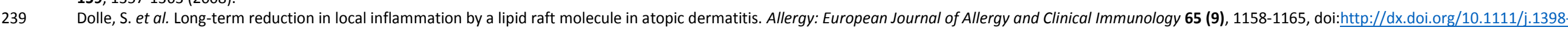
9995.2010.02341.x (2010). 


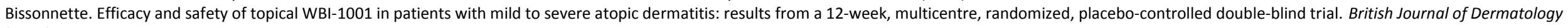
(2012).

Bissonnette, R. et al. Efficacy and safety of topical WBI-1001 in the treatment of atopic dermatitis: results from a phase 2A, randomized, placebo-controlled clinical trial. Archives of dermatology 146, 446-449 (2010). Gandy, J. J. et al. Randomized, parallel-group, double-blind, controlled study to evaluate the efficacy and safety of carbohydrate-derived fulvic acid in topical treatment of eczema. Clinical, Cosmetic and Investigational Dermatology CCID 4, 145-148 (2011).

246 Misery, L., Liege, P. \& Cambazard, F. [Evaluation of efficacy and tolerance of a cream containing raffinose during atopic dermatitis]. Nouvelles Dermatologiques 24, 339-341 (2005).

Katsuyama, M. et al. A novel method to control the balance of skin microflora Part 2. A study to assess the effect of a cream containing farnesol and xylitol on atopic dry skin. Journal of dermatological science $38,207-213$ (2005).

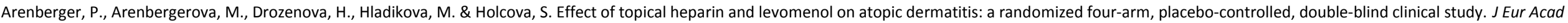
Dermatol Venereol 25, 688-694, doi:10.1111/j.1468-3083.2010.03950.x (2011).

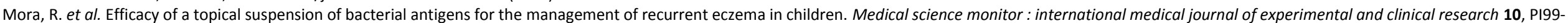
PI103 (2004).

Patzelt-Wenczler, R. \& Ponce-Poschl, E. Proof of efficacy of Kamillosan(R) cream in atopic eczema. European Journal of Medical Research 5, 171-175 (2000).

Hamada, M. et al. The usefulness of camellia oil spray for treatment of atopic dermatitis. [Japanese]. Nishinihon Journal of Dermatology. 70(2)(pp 213-218), 2008. Date of Publication: 2008.

Wu S.-H., C. X.-Q., Liu B., Wu H.-J., Dong L. Efficacy and safety of 15(R/S)-methyl-lipoxin A4 in topical treatment of infantile eczema. British Journal of Dermatology (2013).

Hashizume, E., Nakano, Tetsuo, Kamimura, Ayako, Morishita, Koji. Topical effects of $\mathrm{N}$-acetyl-L-hydroxyproline on ceramide synthesis and alleviation of pruritus. Clinical, cosmetic and investigational dermatology (2013).

Herzog, J. L. et al. A randomized, double-blind, vehicle-controlled crossover study to determine the anti-pruritic efficacy, safety and local dermal tolerability of a topical formulation (SRD174 cream) of the long-acting opiod antagonist nalmefene in subjects with atopic dermatitis. Journal of Drugs in Dermatology 10 (8), 853-860 (2011).

Udompataikul Comparative trial of moisturizer containing licochalcone A vs. hydrocortisone lotion in the trea

Venereology (2011). double-blind, placebo-controlled clinical trial. Giornale italiano di dermatologia e venereologia : organo ufficiale, Societa italiana di dermatologia e sifilografia (2012). Veien, N. K., Kaaber, K., Larsen, P. O., Nielse

Schram. A randomized trial of methotrexate versus azathioprine for severe atopic eczema. Journal of Allergy and Clinical Immunology (2011).

Haeck. Enteric-coated mycophenolate sodium versus cyclosporin A as long-term treatment in adult patients with severe atopic dermatitis: A randomized controlled trial. Journal of the American Academy of Dermatology (2011).

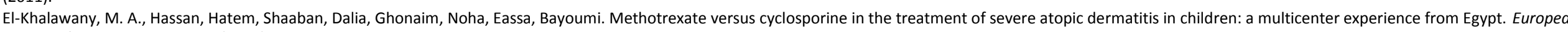
journal of pediatrics, 351 - 356 (2013).

ne antagonist montelukast as a therapeutic agent for atopic dermatitis, Journal of the American Academy of Dermatology 44, 89-93 (2001).

Friedmann, P. S. et al. A double-blind, placebo-controlled trial of montelukast in adult atopic eczema. Clinical and experimental allergy : journal of the British Society for Allergy and Clinical Immunology 37, 1536-1540, doi:10.1111/j.1365-2222.2007.02811.x (2007). Dermatology 53, 147-149 (2005).

Rahman, M. L., Choudhury, A. M. \& Islam, M. M. Effectiveness of montelukast in the treatment of atopic dermatitis. Mymensingh Medical Journal: MMJ 15, 85-88 (2006).

Capella, G. L., Grigerio, E. \& Altomare, G. A randomized trial of leukotriene receptor antagonist montelukast in moderate-to-severe atopic dermatitis of adults. European journal of dermatology : EJD 11, 209-213 (2001).

Pajno, G. B. et al. Sublingual immunotherapy in mite-sensitized children with atopic dermatitis: a randomized, double-blind, placebo-controlled study. Journal of Allergy \& Clinical Immunology 120, 164-170 (2007).

Silny, W. \& Czarnecka-Operacz, M. [Specific immunotherapy in the treatment of patients with atopic dermatitis--results of double blind placebo controlled study]. Polski merkuriusz lekarski : organ Polskiego Towarzystwa Lekarskiego 21, 558-565 (2006).

Oldhoff, J. M. et al. Anti-IL-5 recombinant humanized monoclonal antibody (mepolizumab) for the treatment of atopic dermatitis. Allergy 60, 693-696 (2005).

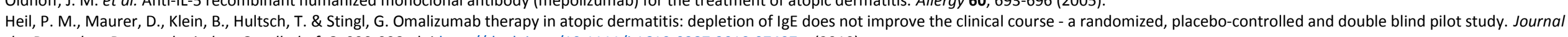
der Deutschen Dermatologischen Gesellschaft 8, 990-998, doi:http://dx.doi.org/10.1111/i.1610-0387.2010.07497.x (2010).

Paul, C., Lahfa, M., Bachelez, H., Chevret, S. \& Dubertret, L. A randomized controlled evaluator-blinded trial of intravenous immunoglobulin in adults with severe atopic dermatitis [see comments]. British Journal of Dermatology 147, 518-522 (2002).

272 Jee. Long-Term Efficacy of Intravenous Immunoglobulin Therapy for Moderate to Severe Childhood Atopic Dermatitis. Asthma, Allergy and Immunology Research (2011).

Wolff, K. et al. Efficacy and tolerability of three different doses of oral pimecrolimus in the treatment of moderate to severe atopic dermatitis: a randomized controlled trial. British Journal of Dermatology 152, 1296-1303 (2005). 
White, C. R. \& Hanifin, J. M. Levamisole therapy in atopic dermatitis. Randomized double-blind evaluation. Archives of Dermatology 114 (9), 1314-1315 (1978).

Hanifin, J. M. et al. Recombinant interferon gamma therapy for atopic dermatitis. Journal of the American Academy of Dermatology 28 (2 I), 189-197 (1993).

Abeck, D. et al. Topical application of a platelet-activating factor (PAF) antagonist in atopic dermatitis. Acta Dermato-Venereologica 77 (6), 449-451 (1997).

Schmitt, J. et al. Prednisolone vs. ciclosporin for severe adult eczema. An investigator-initiated double-blind placebo-controlled multicentre trial. British Journal of Dermatology 162, 661-668 (2010).

Jang, I. G. et al. Clinical improvement and immunohistochemical findings in severe atopic dermatitis treated with interferon gamma. Journal of the American Academy of Dermatology 42, 1033-1040 (2000).

Bemanian, M. H. et al. High doses intravenous immunoglobulin versus oral cyclosporine in the treatment of severe atopic dermatitis. Iranian Journal of Allergy Asthma \& Immunology 4, 139-143 (2005).

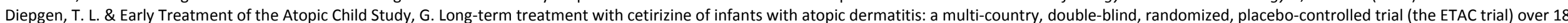
months. Pediatric allergy and immunology : official publication of the European Society of Pediatric Allergy and Immunology 13, 278-286 (2002).

Munday, J. et al. Chlorpheniramine is no more effective than placebo in relieving the symptoms of childhood atopic dermatitis with a nocturnal itching and scratching component. Dermatology 205, 40-45 (2002).

Kawashima, M. et al. Addition of fexofenadine to a topical corticosteroid reduces the pruritus associated with atopic dermatitis in a 1-week randomized, multicentre, double-blind, placebo-controlled, parallel-group study. British Journal of Dermatology 148, 1212-1221 (2003).

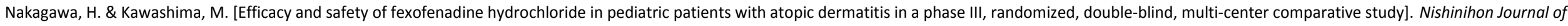
Dermatology 68, 553-565 (2006).

Kawashima. Olopatadine hydrochloride in children: Evidenced efficacy and safety for atopic dermatitis treatment in a randomized, multicenter, double-blind, parallel group comparative study. Nishinihon Journal of Dermatology (2011).

Berth-Jones, J. \& Graham-Brown, R. A. Failure of terfenadine in relieving the pruritus of atopic dermatitis. British Journal of Dermatology 121, 635-637 (1989).

Doherty, V. et al. Treatment of itching in atopic eczema with antihistamines with a low sedative profile. BMJ 298, 96 (1989).

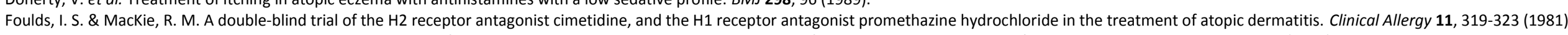

Frosch, P. J., Schwanitz, H. J. \& Macher, E. A double blind trial of H1 and H2 receptor antagonists in the treatment of atopic dermatitis. Archives of Dermatological Research 276, 36-40 (1984).

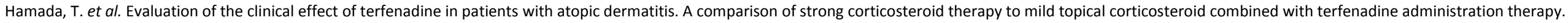
[Japanese]. Skin Research 38 (1), 97-103 (1996).

Hannuksela, M. et al. Dose ranging study: Cetirizine in the treatment of atopic dermatitis in adults. Annals of Allergy 70 (2), 127-133 (1993).

Henz, B. M., Metzenauer, P., O'Keefe, E. \& Zuberbier, T. Differential effects of new-generation H1-receptor antagonists in pruritic dermatoses. Allergy: European Journal of Allergy and Clinical Immunology 53 (2), 180-183

(1998).

Hjorth, N. Terfenadine in the treatment of chronic idiopathic urticaria and atopic dermatitis. Cutis 42 (4 A), 29-30 (1988).

Ishibashi, Y. et al. Clinical evaluation of E-0659 in atopic dermatitis in infants and children. Dose-finding multicenter study by the double-blind method. [Japanese]. Skin Research 31 (3), 458-471 (1989).

Ishibashi, Y. et al. Clinical evaluation of E-0659 on atopic dermatitis. Multicenter double-blind study in comparison with ketotifen. Rinsho Hyoka 17, 77-115 (1989).

Klein, G. L. \& Galant, S. P. A comparison of the antipruritic efficacy of hydroxyzine and cyproheptadine in children with atopic dermatitis. Annals of Allergy 44 (3), 142-145 (1980).

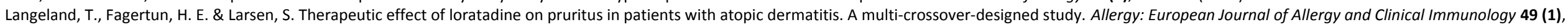
22-26 (1994).

La Rosa, M. et al. Double-blind study of cetirizine in atopic eczema in children. Annals of Allergy 73 (2), 117-122 (1994)

Monroe, E. W. Relative efficacy and safety of loratadine, hydroxyzine, and placebo in chronic idiopathic urticaria and atopic dermatitis. Clinical Therapeutics 14 (1), 17-21 (1992).

Patel, P. et al. A double-blind study of loratadine and cetirizine in atopic dermatitis. Journal of Dermatological Treatment 8 (4), 249-253 (1997)

Savin, J. A., Paterson, W. D., Adam, K. \& Oswald, I. Effects of trimeprazine and trimipramine on nocturnal scratching in patients with atopic eczema. Archives of Dermatology 115 (3), 313-315 (1979).

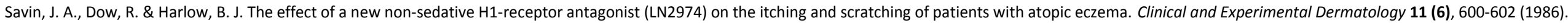
Simons, F. E., Simons, K. J., Becker, A. B. \& Haydey, R. P. Pharmacokinetics and antipruritic effects of hydroxyzine in children with atopic dermatitis. Journal of Pediatrics 104, 123-127 (1984).

Simons, F. E. R. Prospective, long-term safety evaluation of the H1-receptor antagonist cetirizine in very young children with atopic dermatitis. Journal of Allergy and Clinical Immunology 104 (2 I), $433-440$ (1999).

Wahlgren, C. F., Hagermark, O. \& Bergstrom, R. The antipruritic effect of a sedative and a non-sedative antihistamine in atopic dermatitis. British Journal of Dermatology 122 (4), 545-551 (1990).

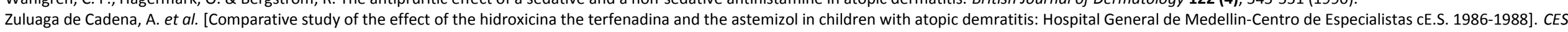
med 3, 7-13 (1989).

Lee, H. J., Park, C. O., Lee, J. H. \& Lee, K. H. [The antipruritic effect of topical doxepin cream in patients with atopic dermatitis]. Korean Journal of Dermatology 44, 309-314 (2006).

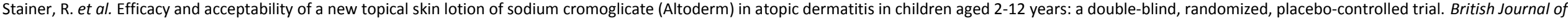
Dermatology 152, 334-341 (2005).

Malekzad, F. et al. Efficacy of oral naltrexone on pruritus in atopic eczema: A double-blind, placebo-controlled study. Journal of the European Academy of Dermatology and Venereology 23, 948-950,

doi:http://dx.doi.org/10.1111/j.1468-3083.2009.03129.x (2009).

Kief, H. [A prospective, controlled study on the efficacy of the treatment with AHIT and treatment with Patient's blood in atopic dermatitis]. Aktuelle Dermatologie 33, 216-227 (2007).

Pittler, M. H. et al. Randomized, double-blind, placebo-controlled trial of autologous blood therapy for atopic dermatitis. British Journal of Dermatology 148, 307-313 (2003).

Byun. Full-spectrum light phototherapy for atopic dermatitis. International Journal of Dermatology (2011).

Brenninkmeijer, E. E. A. et al. Excimer laser vs. clobetasol propionate 005\% ointment in prurigo form of atopic dermatitis: A randomized controlled trial, a pilot. British Journal of Dermatology 163 (4), 823-831,

doi:http://dx.doi.org/10.1111/j.1365-2133.2010.09858.x (2010).

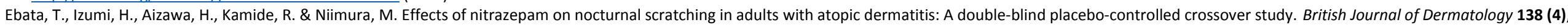
631-634 (1998).

Ruzicka, T. Effect of theophylline in atopic dermatitis: A double-blind cross-over study. Archives of Dermatological Research 269 (1), $109-110$ (1980). 
Archer, C. B. \& Macdonald, D. M. Treatment of atopic dermatitis with salbutamol. Clinical and Experimental Dermatology 12 (5), 323-325 (1987).

Berth-Jones, J. \& Graham-Brown, R. A. Failure of papaverine to reduce pruritus in atopic dermatitis: a double-blind, placebo-controlled cross-over study. British Journal of Dermatology 122, 553-557 (1990). Yoshihara, S. et al. Usefulness of suplatast tosilate, a Th2 cytokine inhibitor based on the Th1/Th2 ratio for allergic disease in children: a retrospective study. Arzneimittel-Forschung, 421-424 (2011).

Kawana, S., Kato, Y. \& Omi, T. Efficacy of a 5-HT1a receptor agonist in atopic dermatitis. Clinical \& Experimental Dermatology 35, 835-840, doi:http://dx.doi.org/10.1111/j.1365-2230.2009.03771.x (2010).

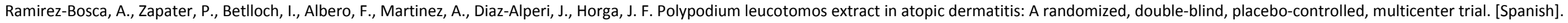
Actas Dermo-Sifiliograficas (2012).

Pfab. Effect of Acupuncture on Allergen-Induced Basophil Activation in Patients with Atopic Eczema: A Pilot Trial. The Journal of Alternative and Complementary Medicine (2011).

Lee. Effectiveness of acupressure on pruritus and lichenification associated with atopic dermatitis: a pilot trial. Acupuncture in Medicine (2012).

Senser, C., Habermuller, M. \& Revenstorf, D. [Hypnotherapy in atopic dermatitis]. Aktuelle Dermatologie 30, 103-108 (2004).

Anderson, C., Lis-Balchin, M. \& Kirk-Smith, M. Evaluation of massage with essential oils on childhood atopic eczema. Phytotherapy Research 14, 452-456 (2000).

Shi, Y. J., Zhang, C. M. \& Ma, D. M. [Clinical study on treatment of atopic dermatitis by integrated traditional Chinese and Western medicine]. [Chinese]. Zhongguo Zhong Xi Yi Jie He Za Zhi Zhongguo Zhongxiyi Jiehe

Zazhi/Chinese Journal of Integrated Traditional \& Western Medicine/Zhongguo Zhong Xi Yi Jie He Xue Hui, Zhongguo Zhong Yi Yan Jiu Yuan Zhu Ban 28, 686-688 (2008).

Henderson, C. A., Morris, A., Wilson, A. \& Ilchyshyn, A. An open study comparing the efficacy of two different Chinese herbal therapy formulations in atopic eczema and their effects on circulating activated T-lymphocytes. Journal of Dermatological Treatment 11, 91-96 (2000).

Hon, K. L., Chan, B. C. \& Leung, P. C. Chinese herbal medicine research in eczema treatment. Chin Med 6, 17 (2011).

Cheng. The Efficacy and Safety of a Chinese Herbal Product (Xiao-Feng-San) for the Treatment of Refractory Atopic Dermatitis: A Randomized, Double-Blind, Placebo-Controlled Trial. International Archives of Allergy \& Immunology (2011)

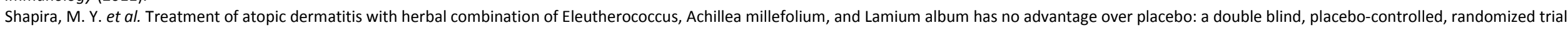
Journal of the American Academy of Dermatology 52, 691-693 (2005).

Alternative \& Complementary Medicine (2012).

Schempp, C. M., Hezel, S. \& Simon, J. C. Topical treatment of atopic dermatitis with Hypericum cream. A randomised, placebo-controlled, double-blind half-side comparison study. (German). Hautart 54, 248-253 (2003). Sheehan, M. P. et al. Efficacy of traditional Chinese herbal therapy in adult atopic dermatitis. Lancet 340 (8810), 13-17 (1992).

Sheehan, M. P. \& Atherton, D. J. A controlled trial of traditional Chinese medicinal plants in widespread non-exudative atopic eczema. British Journal of Dermatology 126 (2), 179-184 (1992).

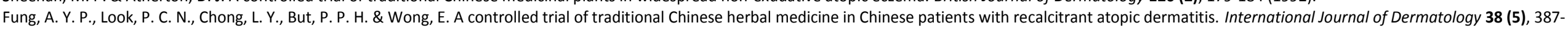
392 (1999).

334

International Archives, P., Poulter, L. W., Rustin, M. \& Brostoff, J. Association

Schachner, L., Field, T., Hernandez-Reif, M., Duarte, A. M. \& Krasnegor, J. Atopic dermatitis symptoms decreased in children following massage therapy. Pediatric Dermatology 15, 390-395 (1998). 
Supplementary Table 2: Criteria used for discussing the risk of bias in the summaries of treatment categories Risk of bias description in the chapter summaries

Collective risk of bias descriptions for summary statements Basis for description

Overall low risk of bias

Method of generating the randomisation sequence, concealment of the allocation sequence, and blinding were assessed as low risk for all the trials summarised

Overall unclear risk of bias

Method of generating the randomisation sequence, concealment of the allocation sequence, and blinding were assessed as unclear risk for all the trials summarised

Method of generating the randomisation sequence, concealment of the allocation sequence, and blinding were assessed as high risk for all the trials summarised

Mostly low risk of bias

A clear majority of the method of generating the randomisation sequence, concealment of the allocation sequence, and blinding

Mostly unclear risk of bias

A clear majority of the method of generating the randomisation sequence, concealment of the allocation sequence, and blinding

Mostly high risk of bias

A clear majority of the method of generating the randomisation sequence, concealment of the allocation sequence, and blinding

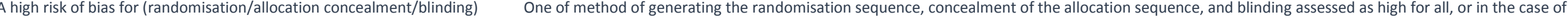

many trials, almost all trials summarised.

A mixed risk of bias The assessments were a fairly even distribution of risk of bias for method of generating the randomisation sequence, concealment of the allocation sequence, and blinding for the trials summarised. 
Supplementary Table 1: Criteria used for discussing the risk of bias in the summaries of treatment categories

\begin{tabular}{|c|c|}
\hline \multicolumn{2}{|r|}{ Risk of bias description in the chapter summaries } \\
\hline $\begin{array}{l}\text { Collective risk of bias } \\
\text { descriptions for summary } \\
\text { statements }\end{array}$ & Basis for description \\
\hline Low & $\begin{array}{l}\text { Method of generating the randomisation sequence, concealment of the } \\
\text { allocation sequence, and blinding were assessed as being low risk for all the } \\
\text { trials summarised }\end{array}$ \\
\hline Unclear & $\begin{array}{l}\text { Method of generating the randomisation sequence, concealment of the } \\
\text { allocation sequence, and blinding were assessed as being unclear risk for all } \\
\text { the trials summarised }\end{array}$ \\
\hline High & $\begin{array}{l}\text { Method of generating the randomisation sequence, concealment of the } \\
\text { allocation sequence, and blinding were assessed as being high risk for all the } \\
\text { trials summarised }\end{array}$ \\
\hline Mostly low & $\begin{array}{l}\text { A clear majority of the method of generating the randomisation sequence, } \\
\text { concealment of the allocation sequence, and blinding were assessed as being } \\
\text { low risk for the trials summarised }\end{array}$ \\
\hline Mostly unclear & $\begin{array}{l}\text { A clear majority of the method of generating the randomisation sequence, } \\
\text { concealment of the allocation sequence, and blinding were assessed as being } \\
\text { unclear risk for the trials summarised }\end{array}$ \\
\hline Mostly high & $\begin{array}{l}\text { A clear majority of the method of generating the randomisation sequence, } \\
\text { concealment of the allocation sequence, and blinding were assessed as being } \\
\text { high risk for the trials summarised }\end{array}$ \\
\hline Mixed & $\begin{array}{l}\text { A fairly even distribution of risk of bias for method of generating the } \\
\text { randomisation sequence, concealment of the allocation sequence, and } \\
\text { blinding for the trials summarised. }\end{array}$ \\
\hline
\end{tabular}




\section{Topical treatments}

Calcineurin Inhibitors

Pimecrolimus (Elidel $\left.{ }^{\circledR}\right)$

Tacrolimus (Protopic ${ }^{\circledR}$ )

\section{Corticosteroids}

Alclometasone dipropionate (Aclovate ${ }^{\circledR}$ )

Betamethasone (Betnovate ${ }^{\circledR}$ )

Clobetasol propionate (Dermovate ${ }^{\circledR}$ )

Clobetasone butyrate (Eumovate ${ }^{\circledR}$ )

Desonide hydrogel (Desonate ${ }^{\circledR}$ )

Desoximetasone (Topicort ${ }^{\circledR}$ )

Fluocinolone acetonide (Derma-Smoothe/FS ${ }^{\circledR}$ )

Fluocinonide $\left(\operatorname{Vanos}^{\circledR}\right)$

Fluticasone propionate (Cutivate ${ }^{\circledR}$ )

Hydrocortisone acetate $\left(\mathrm{Hc}_{\mathrm{c}} \mathrm{5}^{\circledR}\right)$

Hydrocortisone butyrate (Locoid lipocream ${ }^{\circledR}$ )

Hydrocortisone solution (Hydrogelan ${ }^{\circledR}$ )

Methylprednisolone Aceponate (Advantan ${ }^{\circledR}$ )

Mometasone furoate (Elocon $\left.{ }^{\circledR}\right)$

Prednicarbate

Triamcinolone acetonide (Aristocort ${ }^{\circledR} A$ )

Corticosteroids with Antibiotics/Antifungals

Fusidic acid and betamethasone-17-valerate (Fucicort ${ }^{\circledR}$ )

Hydrocortisone and miconazole (Daktacort ${ }^{\circledR}$ )

Triamcinolone acetonide and tetracycline

\section{Antibiotics/antifungals}

Ciclopirox olamine (Batrafen ${ }^{\circledR}$ )

Fusidic acid (Fucidin ${ }^{\circledR}$ )

Mupirocin (Bactroban ${ }^{\circledR}$ )

Bathing-related

Eucalyptus and oat extract mixture bath additive

Sodium hypochlorite (bleach) bath additive

Triclosan (Safeguard ${ }^{\circledR}$ ) soap bar

Emollients (unbranded)

Farnesol and xylitol-containing

Furfuryl palmitate-containing

Glycerine-containing

Triclosan-containing leave-on emollient

Urea-containing

\section{Oral treatments}

Emollients (branded)

A-Derma ${ }^{\circledR}$

Albolene ${ }^{\circledR}$

Aquaphor ${ }^{\circledR}$

Atopiclair $^{\mathrm{TM}}$

Axera $^{\text {TM }}$

Canoderm ${ }^{\circledR}$

Cetaphil ${ }^{\mathrm{TM}}$

EpiCeram

Eucerin $^{\circledR}$

Exomega milk ${ }^{\circledR}$

Hyaltopic ${ }^{\text {M }}$

Lipiderm ${ }^{\circledR}$

Miglyol ${ }^{\circledR}$

Mimy $X^{T M}$

Restoraderm ${ }^{\circledR}$

Stelatopia ${ }^{\circledR}$

Tefirax ${ }^{\circledR}$

\section{Other Topical}

Atopico ${ }^{\circledR}$

Black seed oil

Carbohydrate-derived fulvic acid

Cipamfylline

Cyanocobalamin

Doxepin

Hydroxyproline

Kamillosan ${ }^{\circledR}$

Lipoxin A4

Miltefosine (Miltex ${ }^{\circledR}$ )

Nalmefene (SRD174)

Naltrexone

Rosmarinic acid

Sea buckthorn extract

Sensicutan ${ }^{\circledR}$ with heparin and levomeno

Shale oil

Sodium bituminosulfonate (Ichthosin $\left.{ }^{\circledR}\right)$

Sodium cromoglycate (Altoderm ${ }^{\circledR}$ )

Sorbityl furfural palmitate (AR-GG27 $\left.{ }^{\circledR}\right)$

SRD441

St John's wort

Vitreoscilla filiformis extract

WBI-1001

\section{Immunosupressants}

Azathioprine

Ciclosporin (Neoral $\left.{ }^{\circledR}\right)$

Methotrexate

Mycophenolate sodium

Prednisolone

Antihistamines

Cetirizine $\left(\right.$ Zirtek $^{(\circledR)}$

Chlorpheniramine (Piriton ${ }^{\circledR}$

Epinastine hydrochloride

Fexofenadine $\left(\right.$ Telfast $\left.{ }^{\circledR}\right)$

Ketotifen fumarate (Zaditen ${ }^{\circledR}$ )

Olopatadine hydrochloride

Antifungals

Itraconazole

Ketoconazole (Nizora| ${ }^{\circledR}$ )

\section{Other Oral}

Anapsos ${ }^{\circledR}$

Chinese herbal medicine (various)

Hochu-ekki-to

Naltrexone

Montelukast (Singulair ${ }^{\circledR}$ )

Pimecrolimus

Tandospirone citrate

\section{Dietary}

Borage oil

Evening primrose oi

Fish oil

Hempseed oil

Milk replacements

Prebiotics

Probiotics

Synbiotics

Vitamin D2 and D3

Vitamin $\mathrm{E}$
Loratidine (Clarityn ${ }^{\circledR}$ )

Other types of treatment

Immunoglobulins

Intravenous immunoglobuli

Mepolizumab (intravenous)

Omalizumab (subcutaneous)

\section{Phototherapy}

Full spectrum light therapy

Ultraviolet-A

Ultraviolet-B

Clothing

Ethylene-vinyl alcohol (Mediele ${ }^{(\mathbb{B})}$

Silk (Dermasilk ${ }^{\circledR}$ )

Silver filaments (Padycare ${ }^{\circledR}$ )

Silver coated $\left(X\right.$-Static $\left.{ }^{\circledR}\right)$

Tourmaline coated

Interaction-based

Additional visits to healthcare professionals

Educational

E-health portal

Psychological

Support groups

Complementary

Acupuncture

Acupressure

Aromatherapy and massage

Hypnotherapy

Progressive muscle relaxation

Enviromental

Balneotherapy

House dust mite reduction

lon-exchange water softeners

Visiting a different climate 


\section{MEDLINE (Ovid) Cochrane Collaboration Highly sensitive search string}

1. random\$.mp.

2. factorial\$.mp.

3. (crossover\$ or cross-over\$).mp.

4. placebo\$.mp. or PLACEBO/

5. (doubl\$ adj blind\$).mp. [mp=title, abstract, subject headings, heading word, drug trade name, original title, device manufacturer, drug manufacturer name]

6. (singl\$ adj blind\$).mp. [mp=title, abstract, subject headings, heading word, drug trade name, original title, device manufacturer, drug manufacturer name]

7. (assign\$ or allocat\$).mp.

8. volunteer\$.mp. or VOLUNTEER/

9. Crossover Procedure/

10. Double Blind Procedure/

11. Randomized Controlled Trial/

12. Single Blind Procedure/

13. 1 or 2 or 3 or 4 or 5 or 6 or 7 or 8 or 9 or 10 or 11 or 12

14. exp Dermatitis, Atopic/

15. atopic dermatitis.mp.

16. atopic eczema.mp.

17. exp NEURODERMATITIS/

18. neurodermatitis.mp.

19. infantile eczema.mp.

20. childhood eczema.mp.

21. (besnier\$ and prurigo).mp. [mp=title, abstract, subject headings, heading word, drug trade name, original title, device manufacturer, drug manufacturer name]

22. eczema.mp. or exp Eczema/

23. 21 or 17 or 20 or 15 or 14 or 22 or 18 or 16 or 19

24. 23 and 13

\section{EMBASE search string (Ovid)}

1. random\$.mp.

2. factorial\$.mp.

3. crossover\$.mp.

4. placebo\$.mp. or PLACEBO/

5. (doubl\$ adj blind\$).mp. [mp=title, abstract, subject headings, drug trade name, original title, device manufacturer, drug manufacturer name] 6. (singl\$ adj blind\$).mp. [ $\mathrm{mp}=$ title, abstract, subject headings, drug trade name, original title, device manufacturer, drug manufacturer name] 7. assign\$.mp.

8. volunteer\$.mp. or VOLUNTEER/

9. Crossover Procedure/

10. Double Blind Procedure/

11. Randomized Controlled Trial/

12. Single Blind Procedure/

13. 1 or 2 or 3 or 4 or 5 or 6 or 7 or 8 or 9 or 10 or 11 or 12 